NBER WORKING PAPER SERIES

\title{
THE EFFECTS OF JOB CHARACTERISTICS ON RETIREMENT
}

\author{
Péter Hudomiet \\ Michael D. Hurd \\ Andrew Parker \\ Susann Rohwedder \\ Working Paper 26332 \\ http://www.nber.org/papers/w26332 \\ NATIONAL BUREAU OF ECONOMIC RESEARCH \\ 1050 Massachusetts Avenue \\ Cambridge, MA 02138 \\ October 2019
}

This research was supported by the Alfred P. Sloan Foundation (G-2014-13537). The data collection was jointly funded by the same grant from the Alfred P. Sloan Foundation and by a grant from the National Institute on Aging (P01AG008291). Jessica Hayes provided excellent programming assistance. The views expressed herein are those of the authors and do not necessarily reflect the views of the National Bureau of Economic Research.

NBER working papers are circulated for discussion and comment purposes. They have not been peerreviewed or been subject to the review by the NBER Board of Directors that accompanies official NBER publications.

C 2019 by Péter Hudomiet, Michael D. Hurd, Andrew Parker, and Susann Rohwedder. All rights reserved. Short sections of text, not to exceed two paragraphs, may be quoted without explicit permission provided that full credit, including $(\mathrm{C}$ notice, is given to the source. 
The Effects of Job Characteristics on Retirement

Péter Hudomiet, Michael D. Hurd, Andrew Parker, and Susann Rohwedder

NBER Working Paper No. 26332

October 2019

JEL No. J14,J24,J26

\begin{abstract}
$\underline{\text { ABSTRACT }}$
This paper presents results based on a survey fielded in the RAND American Life Panel that queried older workers about their current, desired, and expected job characteristics, and about how certain job characteristics would affect their retirement. Having access to flexible work hours was found to be the most consistent predictor of retirement expectations. For example, we estimated that the fraction of individuals working after age 70 would be $32.2 \%$ if all workers had flexible hours, while the fraction working would be $17.2 \%$ if none had the option of flexible hours. We further found that job stress, physical and cognitive job demands, the option to telecommute, and commuting times were also strong predictors of retirement expectations. By comparing workers' current job characteristics with those that individuals desire, we show that people would like preretirement jobs to be less cognitively and physically demanding and more sociable compared to their current jobs. We also find that most workers worry about their health and the demands of their jobs when they think about their future work trajectory, but relatively few were worried that their employers would retain them. Having access to part-time jobs, and expected longevity were less important predictors of retirement.
\end{abstract}

Péter Hudomiet

RAND Corporation

1776 Main Street

Santa Monica, CA 90407

hudomiet@rand.org

Michael D. Hurd

RAND Corporation

1776 Main Street

Santa Monica, CA 90407

and NBER

mhurd@rand.org
Andrew Parker

RAND Corporation

4570 Fifth Ave \#600,

Pittsburgh, PA 15213

parker@rand.org

Susann Rohwedder

RAND Corporation

1776 Main Street

Santa Monica, CA 90407

susannr@rand.org 


\section{Introduction}

The share of older individuals in the total population has been increasing because mortality and fertility rates have been declining in recent decades, and this trend is predicted to continue (Mather, Jacobsen, \& Pollard, 2015). Consequently, it has been argued that it would be beneficial if people worked longer and delayed retirement. Longer work lives would help individuals maintain their standard of living after retirement by increasing their lifetime income. Longer work would also relieve some of the financial pressures on public programs such as Social Security, Medicare, and Medicaid.

There are, however, barriers that may prevent people from delaying retirement. Physical abilities and critical dimensions of cognitive ability decline with age (Spirduso, Francis, \& MacRae, 2005; Salthouse, 2012) and, depending on the job characteristics of older workers, it may be difficult for some to remain productive at advanced ages (Belbase, Sanzenbacher, \& Gillis, 2016; Hudomiet, Hurd, Rohwedder, \& Willis, 2018a). Older workers may also differ from their younger peers in terms of preferences for jobs with particular characteristics. It is therefore important to know what types of jobs older workers want, which types are available to them, and how the availability of these working conditions affects older workers' retirement decisions.

In this paper we present results from a recent survey fielded in the RAND American Life Panel (ALP) that queried older workers about their preferred retirement pathways; their current, desired, and expected job characteristics; as well as about how certain job characteristics would affect their retirement decisions. Some of the questions are qualitative, while others allow the effect of a certain factor on the timing of retirement to be quantified. With respect to a variety of job attributes, we use a novel methodology called Subjective Conditional Probabilities, which 
elicits the subjective probability of working after age 70 conditional on different job characteristics and other factors. These measures are discussed in detail in an earlier paper by us (Hudomiet, Hurd, \& Rohwedder, 2018b), in which we show that the measures pass a number of internal and external consistency checks and they offer a useful tool to study causality when randomized controlled trials (RCTs) or natural experiments are not at hand.

A number of studies have used the Health and Retirement Study (HRS) to investigate the factors that influence retirement, such as Barnes-Farrell (2003); Beehr \& Bennett (2015); Bound, Cullen, Nichols \& Schmidt (2004); Bound, Stinebrickner \& Waidmann (2010); Feldman \& Beehr (2011); Fisher, Chaffee, \& Sonnega (2016); French \& Jones (2011); Gruber \& Wise (2004); Gustman \& Steinmeier (2005); Maestas, Mullen \& Strand (2013). However, from the observed retirement trajectories one cannot infer preferred trajectories or desired job attributes that are more relevant for policy design. To the extent that individuals' choices are constrainedfor example, due to limited availability of the type of jobs they would prefer or due to health shocks or the need to take care of someone else - workers' preferences for retirement pathways and job attributes will differ from observed patterns.

Even though older workers' preferences for job characteristics are of central importance in retirement research, it is very hard to measure them reliably. First, preferences are not directly observable in surveys or other datasets. Second, RCTs are rarely feasible or ethical in retirement research. Third, observational data about the correlations between working conditions and retirement patterns are unlikely to show causal relationships, because of the sorting of different types of workers into different types of jobs. Even though there is large heterogeneity in job attributes, this heterogeneity is strongly selective: Workers in "good jobs" tend to enjoy more perks than workers in "bad jobs." 
An alternative avenue is a stated preferences approach using specialized surveys to measure older workers' preferences for job characteristics. Maestas, Mullen, Powell, von Wachter, \& Wenger (2018), for example, used a vignette methodology to study workers' (both young and old) willingness to pay for various job amenities. They found that older workers would be willing to pay relatively more for better job amenities, and they care most about the availability of paid time off, moderate physical activities, the opportunity to sit, job autonomy, and flexibility over their work hours. Van Soest, Kapteyn, \& Zissimopoulos (2007) elicited the preferences of Dutch respondents asking them to rate hypothetical retirement trajectories involving early retirement, late retirement, and gradual retirement, each with its own corresponding income path. They found that many respondents would be willing to work parttime after age 65 in return for a reasonable compensation.

Adding to this line of study, our survey queried older workers about their work and retirement preferences. We analyzed four sets of outcome variables: First, we listed nine alternative work-to-retirement pathways, which differed in the timing of retirement as well as how gradual the process was, and asked survey participants to rate these pathways. Second, we asked workers about their current and expected future job demands and job characteristics, such as flexible work hours or physical demands of work. Third, we asked individuals about the subjective probabilities that they would work after age 70. Fourth, we asked individuals about the subjective probabilities of working after age 70 conditional on different job characteristics and other factors.

The path from work to retirement can take many forms. Some people work full-time up to a certain age and then withdraw completely from the labor force, while others retire gradually, shifting from full-time to part-time work and eventually retire completely. Self-employment rates 
are also higher at older ages (Karoly \& Zissimopoulos, 2004; Quinn, 1996), offering another option to older workers. Based on data from the HRS, Hudomiet, Parker, \& Rohwedder (2018c) documented the distribution of the various retirement pathways for the cohort of full-time workers who were 55 to 58 years old between 1992 and 1998. They found that only $37 \%$ followed the "traditional" path to retirement, transitioning from full-time work directly to fullretirement in their 60s. An important aspect of our survey is that we ask individuals about their preferences for various work-to-retirement pathways that we can compare, to the extent possible, to such observed pathways.

This paper first describes the data and our statistical approach. Our presentation of empirical results starts out with descriptive statistics of how the outcome variables relate to covariates of interest, such as gender and labor force status, and then follows with OLS regressions that include "standard" and "less standard" predictor variables. Among the standard ones, we consider demographics, socio-economic status, health, and workers' current job characteristics. An innovative feature of this project is to include psychological predictor variables in the regression models: a measure of fluid cognitive ability, and the Big 5 personality traits. Such psychological factors may be related to workers' preferences for different working conditions and leisure activities, and they may predict heterogeneity in the retirement choices of individuals even after the standard economic variables are controlled for in the statistical models. In our earlier paper (Hudomiet et al., 2018c) we found that these psychological factors predicted the retirement pathways of individuals in the HRS, but the available data did not allow shedding light into underlying mechanisms. 


\section{Data}

\section{The RAND American Life Panel}

The American Life Panel (ALP) is an ongoing Internet panel survey operated by RAND (Baird \& Pollard, 2017). It is a nationally representative, probability-based sample of about 6,000 participants, who are at least 18 years old, speak either English or Spanish, and live in the United States. Respondents receive email invitations to complete questionnaires about twice a month. The ALP has conducted over 500 surveys since its inception in 2003.

The majority of the panel members access the surveys using their own computers, laptops, or cell phones, but RAND provides a laptop or an Internet service subscription or both for panel members who need them. The sample, thus, does not suffer from selection bias related to households' access to the Internet. Post-stratification weights are applied to adjust the distribution of age, sex, ethnicity, education, and income, respectively, to those in the Current Population Survey.

The surveys typically take no more than 30 minutes to complete, and respondents are paid an incentive of about $\$ 20$ for a 30-minute survey, or less for shorter surveys. Response rates are typically between $75 \%$ and $85 \%$ of enrolled panel members, depending on the topic, time of year, and length of time a survey is kept in the field.

\section{ALP survey on working longer}

The survey we used in this project was fielded from December 2017 to February 2018 to the 5079-year-old English-speaking members of the ALP. The survey was started by 2,374 individuals. Our analytic sample consists of the 2,177 people who: (1) finished the survey; (2) answered some of the basic questions in the survey (labor force status, self-assessed health, personality 
questions); and (3) had some attachment to the labor force. The latter requirement is important due to this study's focus on retirement pathways and working conditions. A person was considered "attached" to the labor force if any of the following was true:

1. He or she worked at the time of the survey.

2. He or she worked for at least five of the previous 15 years (if younger than 65).

3. He or she worked for at least five years after the age of 50 (if older than 65).

Table 1 shows weighted and unweighted descriptive statistics about our sample. About half of the weighted sample is female, two-thirds are non-Hispanic white, $11 \%$ are non-Hispanic black, and $16 \%$ are Hispanic. The sample is diverse in terms of education, marital status, selfassessed health, labor force status, and income. Regarding highest level of education achieved, about one-third said high school; one-third said some college; and one-third said at least a college degree. About two-thirds of participants are married, and more than $80 \%$ reported "excellent," "very good," or "good" health. At the time of the survey, 29\% were not working, $48 \%$ were full-time employees, $13 \%$ were part-time employees, and $10 \%$ were self-employed. We also measured psychological factors that may be relevant for retirement, including a number series score, which is a measure of fluid intelligence (McArdle, Smith, \& Willis, 2009); and the Big 5 personality traits: neuroticism (emotional stability), ${ }^{1}$ extroversion, agreeableness, conscientiousness, and openness to new experiences (see John \& Srivastava (1999) for an overview of the measures' development; and Borghans, Duckworth, Heckman, \& ter Weel (2008) for their predictive power of economic outcomes). The psychological factors were created

\footnotetext{
${ }^{1}$ The literature sometimes uses "emotional stability" to refer to the inverse of neuroticism, and we use both terms in this study.
} 
using the same items and coding procedure as in the Health and Retirement Study. ${ }^{2}$ We then standardized these factors to have 0 means and standard deviations of 1.0 in the unweighted sample.

By comparing the weighted and the unweighted means in Table 1, we can see how representative the unweighted ALP sample is. Though the weighted and unweighted numbers are similar, the unweighted sample has a noticeably higher fraction of white, more educated, and somewhat older respondents than the weighted sample. The unweighted fraction of non-workers and average number series score exceed the weighted fraction and average. These are in line with earlier findings indicating that internet survey participants tend to be somewhat more educated and more affluent than the general population (Baird \& Pollard, 2017; Börsch-Supan \& Winter, 2004).

Most of the survey focused on older individuals' attitudes, preferences, and expectations about retirement, and how job characteristics affected them. This paper concentrates on four sets of measures:

1. Preferences for various work-to-retirement pathways, such as working in a full-time job until age 62, then taking a part-time job, and finally retiring at age 70 .

2. Workers current and expected future job demands and job characteristics, such as flexible work hours or physical demands of work.

3. Subjective probabilities of working after age 70 .

\footnotetext{
2 The number series score is based on an adaptive test, in which each survey participant answers six questions, and the difficulty of the last three items depends on the participant's performance on the first three. Fisher, McArdle, McCammon, Sonnega, \& Weir, (2013) explain the coding procedure in detail. For the Big 5 personality traits respondents rate themselves using a scale from "not at all" to "a lot" on 26 adjectives, and the appropriate items are averaged, as explain by Smith, Fisher, Ryan, Clarke, House, \& Weir, (2013).
} 
4. Subjective conditional probabilities of working after age 70. These questions asked about the probabilities of working after age 70 conditional on various hypothetical scenarios, such as having flexible working hours or less stressful work environment.

These measures will be overviewed in detail in the next section, right before we present our results.

\section{Results}

Unless noted, all statistics shown in the results section are weighted by the survey weights provided by ALP.

\section{Desired work-to-retirement pathways.}

The pathways from work to retirement can take different forms. Some people fully retire directly from their career jobs at the early or normal retirement age, while others retire at earlier or later ages, and still others leave the labor force more gradually, by taking up part-time jobs or self-employment before leaving the labor force entirely (Beehr \& Bennett, 2015; Hudomiet et al., 2018c; Kantarci \& van Soest, 2008; Maestas, 2010). For example, in our earlier work (Hudomiet et al., 2018c), we investigated the work-to-retirement pathways of about 3000 individuals in the HRS from about age 56 to 70 who were full-time workers at baseline. We found that only $37 \%$ of individuals followed the "standard" pattern of retiring directly and completely from a full-time job; $14 \%$ took part-time jobs before retirement, $10 \%$ remained in full-time jobs until age $70,16 \%$ switched to a part-time job and did not retire until age 70 , and the rest (24\%) followed more complex retirement pathways. Because of the recent rise in the share of individuals working in 
alternative work arrangements (Katz \& Krueger, 2016) such as Uber, it is possible that the role of non-traditional retirement pathways will increase further in the future.

Little is known about why the non-traditional retirement pathways are so common in the U.S. It is conceivable that older workers desire a more gradual exit from the labor force, because these alternative jobs align better with their changing preferences, capabilities and health compared to their career jobs. These non-standard work-to-retirement pathways, however, may also differ from workers' preferred pathways. Some older workers, for example, may be forced out of their career jobs in their 60s, driving them into alternative work arrangements. Nontraditional pathways, thus, may be common due to older workers' preferences or due to outside constraints. To explore the importance of the preference mechanism, we asked individuals in the survey to rate nine different work-to-retirement pathways with scores ranging from 0 (very unfavorable) to 10 (very favorable). The pathways differed in terms of when the person retired, and whether retirement occurred directly from full-time jobs or more gradually through part-time or self-employment jobs. ${ }^{3}$ The nine pathways were the following:

1. Work full-time and retire completely at age 62 .

2. Work full-time and retire completely at age 65 .

3. Work full-time and retire completely at age 70 .

4. Start working part-time at age 62 and retire completely at age 65 .

5. Start working part-time at age 62 and retire completely at age 70 .

\footnotetext{
${ }^{3}$ Our original aim was to measure workers' preferred work-to-retirement pathways holding their wage rate constant. Because of the complexity of the pathways, providing precise instructions for this was challenging, especially in view of constraints on available survey time for this question. We decided to use a simpler wording that allowed workers to interpret "preferred" retirement pathways more freely. The lack of precise instructions may have led to some uncertainty about the interpretation of these questions. At the same time, most workers considering retiring earlier/later, with or without including part-time work, presumably realized that part-time jobs pay less, but allow more leisure time. In that sense, the wording employed may be realistic.
} 
6. Start working part-time at age 65 and retire completely at age 70 .

7. Become self-employed at age 62 and retire completely at age 70 .

8. Never retire

9. Retire at age 62 , start working again at age 65 and retire completely at age 70 .

We identified an individual's preferred pathway as the one that received the highest score from this list. When multiple pathways received the highest scores, we randomly selected one of their top choices as "preferred." 164 individuals who gave the same rating to all pathways were dropped from this analysis. Most of them (76\%) gave 0,1 , or missing ratings to all pathways. Table 2 shows, by gender and current labor force status, the fractions of the sample, respectively, who preferred different work-to-retirement pathways. The pathways are listed in the rows, and the columns correspond to the different samples. Appendix Table B1 shows the average of individuals' reported $0-10$ ratings.

Our main question is how popular (preferred) the alternative work-to retirement pathways are compared to the standard "full-time $\rightarrow$ retirement" pathways. Individuals' reports may be compared to the literature on workers' realized pathways, but due to differences in the samples as well as the definitions of the objective and subjective pathways such comparisons have limitations.

The standard pathways appear to be the most popular work-to-retirement pathways. The most frequently preferred pathway is working in full-time jobs, and then retiring completely at age 62: more than $28.5 \%$ of the sample would prefer to retire this way. The second and third most-frequently-preferred pathways are similar, but the age of retirement is 65 or 70 . While these traditional retirement pathways are more popular than the gradual pathways through part-time jobs or self-employment, one size does not fit all, and we see large heterogeneity among the 
population in their preferences for the different pathways. More than $50 \%$ of the sample prefer one of the three "traditional" pathways; almost 1 in 4 prefer first taking part-time jobs; and almost $10 \%$ prefer a period of self-employment before retirement. Never retiring is the preferred route for a little over $10 \%$ of the sample. These results are more or less in line with the literature showing that non-traditional retirement pathways are very common in the U.S. The standard retirement pathways, however, appear to be somewhat more popular than realized in the data: $53 \%$ of our sample would prefer one of the standard retirement pathways in contrast to only $37 \%$ of the HRS sample that followed such pathways (Hudomiet et al., 2018c).

The ratings of males and females are similar, though females are somewhat more likely to prefer the gradual pathways through part-time jobs, and they are less likely to prefer selfemployment and never retiring.

We see large differences by labor force status, and the results are consistent with the notion that individuals self-select into labor force status based on their preferences: While fulltime employees and retired individuals show stronger preferences for retiring directly from fulltime jobs, part-time employees and the self-employed are almost indifferent toward the traditional and the gradual pathways. The preferred pathway among part-time employees is still full-retirement at age 62 (chosen by $22.8 \%$ ), while the preferred pathway among the selfemployed is gradual retirement through self-employment and never retiring. Overall, we find large heterogeneity in retirement preferences, which lines up reasonably well with older workers' observed labor force statuses.

To investigate heterogeneity in retirement preferences in more detail, Table B2 in the appendix shows OLS regressions of the various pathways as a function of demographics, health, labor force status, and psychological factors. We found that the effect of labor market status is 
similarly strong compared to the results shown in the cross-tabulations above; and that gender, education, age, self-rated health, cognitive ability and the Big 5 personality traits are all quite strong predictors of retirement preferences. For example, traditional retirement is more popular among males, and less popular among those with higher cognitive ability and those who are more open to new experiences; part-time jobs are more popular among females, people with high cognitive ability; and self-employment is less popular among more neurotic and conscientious people. It is hard to know if these associations reflect causal mechanisms, but it is interesting to see how strongly demographics, and psychological factors predict preferences.

\section{Job demands and job characteristics}

\section{Constraints and job demands}

We showed evidence in the previous section that older workers' preferences for different work-to-retirement pathways lined up reasonably well with observed pathways. It does not mean, however, that preferences perfectly predict realizations. To investigate the role of other factors, such as external constraints and the importance of labor demand, the survey queried older employees about how various factors would affect their abilities to keep their jobs until age 70 . The question wording was the following:

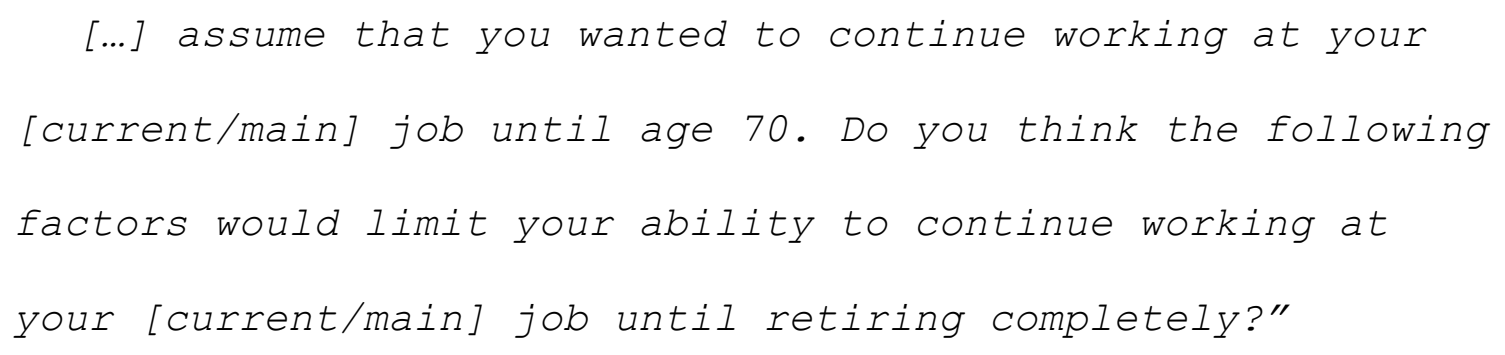

We asked about the following factors:

1. Health problems

2. Demands of the job 
3. Having to take care of others

4. Business conditions

5. Employer would not extend contract

The answer options were (1) Not at all, (2) Somewhat, (3) Moderately, or (4) Greatly. Table 3 shows the distribution of the answers in the sample of employees. Health problems and job demands were reported to be the most important factors, on average. More than $50 \%$ of employees reported that health problems would moderately or greatly affect their ability to keep their jobs until age 70 . Almost $50 \%$ identified demands of the job as moderately or greatly important factors. An interpretation is that these workers foresaw an increasing mismatch between their ability to perform the job and the demands of the job, which, at some point would not permit them to work until age 70. Fewer workers worried about the continuing availability of their job (labor demand): a little over half of the sample said that they were not at all worried that their employers would not extend their contract. We interpreted this to mean that most thought their employer would allow them to work until age 70 . Just $15.2 \%$ were greatly worried about it. Business conditions in general were somewhat more frequently identified as a potential barrier, but the most frequent answer was still "Not at all", chosen by $33.2 \%$ of the sample. Worrying about caretaking obligations showed the largest heterogeneity in the sample: $24.9 \%$, $34.9 \%, 21.4 \%$, and $17.8 \%$ of the sample identified said caretaking would "Not at all," "Somewhat," "Moderately," or "Greatly" affect their abilities to keep their jobs until age 70. This heterogeneity is likely related to family size and composition, but lacking information about families in the survey, we could not investigate this explanation further.

Overall, it appears that health and demands of the job are the factors that older workers most frequently worry about when they plan the length of their working lives. Table 3 , however, 
does not identify what characteristics of the job older workers want. To learn about these issues, we next look into detailed job features.

\section{Current, and last job features compared to desired future job features}

Respondents were asked about the features and requirements of their current or last jobs along 14 dimensions, such as physical and cognitive demands and the social climate of the workplace (Morgeson \& Humphrey, 2006). There were six cognitive items:

1. My job requires monitoring a great deal of information.

2. My job requires engaging in a large amount of thinking.

3. My job requires a variety of skills.

4. My job requires using a number of complex or high-level skills.

5. At my job the tasks are simple and uncomplicated.

6. At my job I solve problems that have no obvious correct answers.

The survey included two items to capture the physical intensity of the jobs:

1. My job requires a great deal of muscular strength.

2. My job requires a lot of physical effort.

Four items measured social features:

1. At my job the people I work with are friendly.

2. At my job I have the chance to get to know other people.

3. At my job I have the opportunity to develop close friendships.

4. At my job the people I work with take a personal interest in me.

The survey also measured two other job characteristics:

1. At my job the climate is comfortable in terms of temperature and humidity.

2. At my job I make my own decisions about how to schedule my work. 
Respondents chose from the options: (1) Absolutely yes, (2) Partly yes/partly no, (3) Absolutely no, or (4) It did not matter to me (for some questions). We converted these responses to a 0 to 1 scale: "absolutely no" answers were coded as zero; "partly yes/partly no," "it did not matter to me," and missing answers were coded as 0.5 , and "absolutely yes" answers were coded as 1 . The one exception was the "At my job the tasks are simple and uncomplicated" feature, which was reversed so that higher values correspond to cognitively more challenging jobs.

We also created three aggregate variables: cognitive, physical, and social job features, by taking the average of the relevant items for each. These aggregate scores are also between 0 and 1, and larger numbers indicate more-cognitive, more-physical, or more-social jobs.

Table 1 shows the mean of these indices in workers' current jobs, or latest jobs if they did not work at the time of the survey. Their jobs have relatively high cognitive requirements: the average is about 0.70 which is almost half way from "partly yes/no" to "absolutely yes." The physical requirements are much lower. Social opportunities appear to be widely available. The means of workers' current and non-workers' latest jobs are similar in all three dimensions.

Later in the survey we asked individuals to rate a future job along the same 14 dimensions. The future job would be a job they would try to get after age 60 (for those below age 60 ), or in the future (for those above 60). The question wording was:

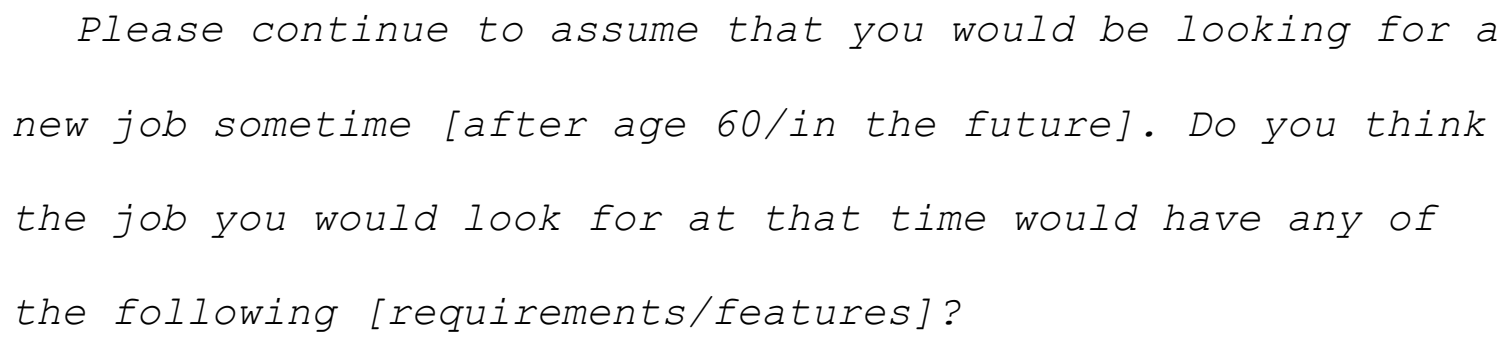

The question used a natural wording, but these are the jobs they would look for, so we sometimes interpret the answers as showing individuals' desired future job characteristics. 
Table 4 shows the average values, stratified by gender, of the 14 individual and three aggregate measures of job features for individuals' current and future jobs. Table 5 shows them stratified by labor force status. Because we compare current and desired future job features, the samples used for the tables are restricted to individuals who worked for pay at the time the survey was fielded.

Individuals' current jobs score relatively high in cognitive and social domains ( 0.670 and 0.687 respectively on the $0-1$ scale) and relatively low in physical domains $(0.348)$. The jobs people would like to get in the future are less cognitive (0.539), and even less physical (0.176) than their current jobs, while they are slightly more social $(0.715)$. People would also like to have a more comfortable temperature at their workplaces and future jobs with flexible schedules. The individual items follow similar patterns to the three aggregate scores with some exceptions. For example, individuals would like to get future jobs with lower cognitive demands in most dimensions, but they desire an increase in "solving problems."

The patterns are qualitatively similar among males and females, but females are in cognitively and physically less demanding jobs.

Cognitive demands are highest among full-time employees (0.712) compared to part-time employees (0.538), and the self-employed (0.636). The desired future jobs have lower average cognitive scores than the current jobs in all three groups, but the difference is largest among fulltime employees who have the highest baseline value (a drop of more than 0.15). Physical demands are slightly higher among part-time employees and the self-employed, but the patterns are similar. Social demands do not vary much by labor force status.

It would be interesting to know if these patterns are different in the public vs. private sectors, but unfortunately our survey did not ask about workers' sectors. Table B3 in the 
Appendix shows some suggestive evidence that current and future job demands do not vary much by sectors. ${ }^{4}$

To investigate heterogeneity in more detail, Appendix Tables B4 and B5 show the results of OLS regressions on current and future job features as well as their differences. We found that females desire a significantly larger drop in cognitive demands compared to men. Higher family income predicts a larger drop in the desire for cognitive and social demands, because higherincome individuals are currently in more-cognitive and more-social jobs, but the desired future jobs do not vary much by income. Some psychological factors are strong predictors of job features, as they were of preferred retirement pathways. For example, individuals with higher cognitive ability desire a smaller decline in cognitive job demands. Individuals who score higher on the neuroticism scale desire a larger increase in the social aspects of their jobs; while more extroverted participants desire a larger reduction in jobs' cognitive and physical aspects; more agreeable individuals desire smaller declines in physical and larger increases in social aspects of their jobs; and more conscientious individuals also desire smaller declines in physical job demands, but their desired increase in social demands would be smaller.

Overall, it appears that the average older worker would prefer moving into jobs with lower cognitive and physical demands, but there is strong heterogeneity in these preferences. It is an interesting question if such jobs are in fact available to them.

\footnotetext{
${ }^{4}$ Table B3 is based on information from three other ALP surveys preceding ours by $0-2$ years. We managed to link about $2 / 3$ of our sample to at least one of these other samples, and we used sector information from the latest available survey. Of course, this information may be selective and outdated so we do not use it in our main analysis. But based on Table B3, current and desired job features look similar in the private and public sectors, and only slightly different in the non-profit sector. These latter jobs appear a bit more cognitive and social and less physical than average.
} 


\section{Availability of job characteristics}

We study the availability of four job characteristics elicited in the survey. The first one asked about the subjective probability that full-time workers could switch to a part-time position if they wanted to:

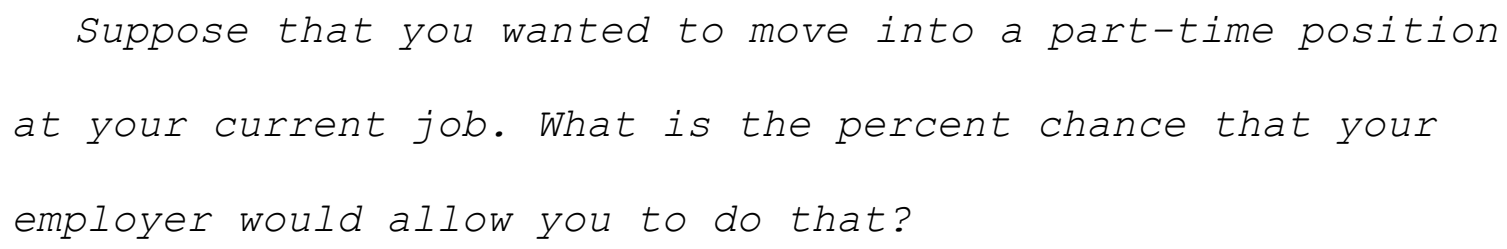

The second one asked a similar question about the possibility to flexibly choose work hours:

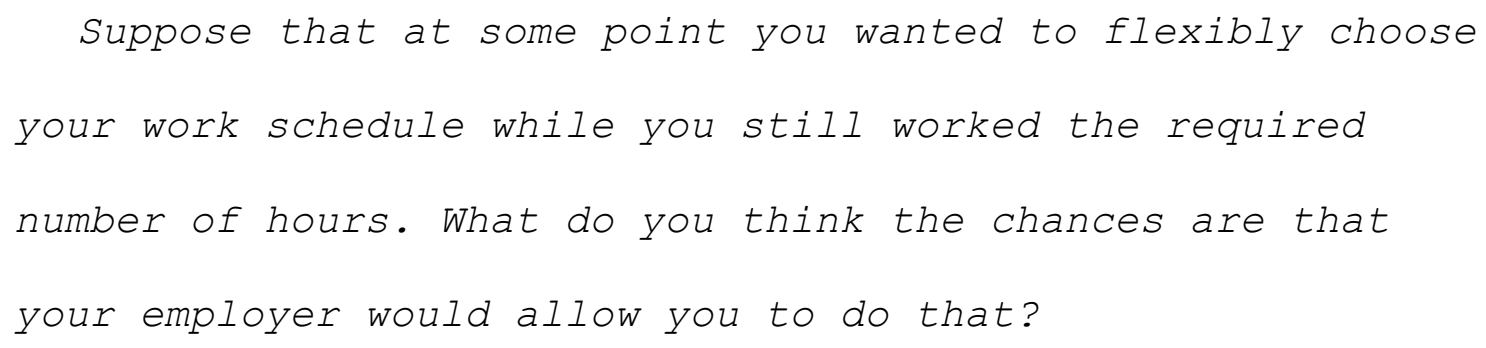

The third question asked about telecommuting, and the wording depended on job-type. Employees were asked if their employers allowed them to work from home at least occasionally. Self-employed people were simply asked if they could work from home.

The fourth question asked about average total commuting time.

Table 6 shows the averages of these measures by gender and labor market status. The average subjective probability of being allowed to switch to a part-time position is $40.7 \%$, and it is significantly higher among females (47.0\%) compared to males (35.8\%).

The sample average of the subjective probability of being allowed to flexibly choose work hours is similar, $39.8 \%$, and it is also higher among females compared to males (43.1\% vs. $36.8 \%$ ). We found very large differentials by employees' current work hours: flexibility in work hours is far less likely in full-time jobs (36.0\%) compared to part-time jobs $(56.2 \%)$. 
About $43.1 \%$ of workers are allowed to telecommute, and this fraction is slightly higher among females: $45.2 \%$ compared to $41.2 \%$ among males. Telecommuting is far more common among the self-employed. For example, $87.0 \%$ of part-time self-employed workers can telecommute, while only $32.2 \%$ of part-time employees report that this option is available to them.

On average, older workers commute for about an hour a day (64.9 minutes). Males and females commute for about the same time, but there is some variation by labor market status. Part-time employees commute the most (74.2 minutes), and part-time self-employed people commute the least (44.3 minutes).

Table B6 in the appendix shows OLS regressions of these three measures. The relationships suggest that high SES individuals have better access to better working conditions. For example, work hour flexibility increases with education and income; telecommuting increases by income; and minorities have longer commutes. Health, job features, and psychological factors also predict the outcome variables.

Overall, we see that favorable working conditions (i.e. the ones that offer more flexibility and are closer to home) are widespread among older workers in the U.S., but they are far from being universal.

\section{Subjective probabilities of working after age 70}

In this section we investigate how job characteristics predict retirement behavior as measured by the reported subjective probabilities of working after age 70, which we call P70. The survey asked the following question:

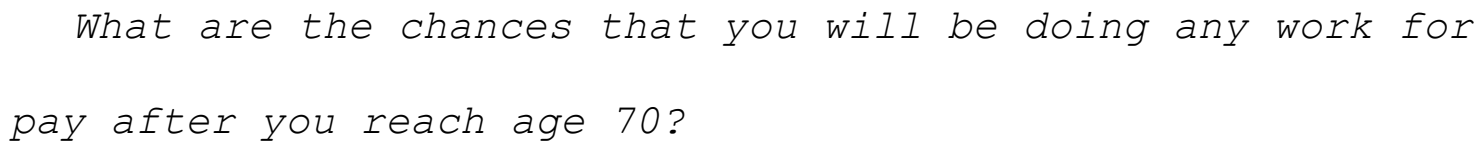


We analyze the target age 70 rather than, say, 65 because the labor force participation rate after age 65 has been rapidly increasing and because of discussion about increasing the full Social Security retirement age beyond age 67. At times we will call P70 a measure of "labor supply."

Table 7 shows how P70 varies by job constraints (analyzed in Table 3), current and future job features (Tables 4 and 5), and job characteristics (Table 6). Column 1 shows the means of P70 in the sample with low values of the explanatory variable (i.e. not important, not available, or below median), column 2 shows the means for high values (i.e. important, available, or above median), and column 3 shows the difference. For example, among those who say health problems would not be important in working to age 70, the average P70 is 34.6 ; among those who said health would be important the average P70 was 31.7. Table 8 shows the OLS regression version of this table, in which we also control for demographics, health, income, labor force status, and psychological factors.

In Table 3 we saw that many workers consider demands of the job an important factor for their ability to keep their jobs until age 70 . According to Table 7, this variable is also a very strong predictor of P70. Those who are more worried about job demands, expect a 7.9 percentage point lower likelihood of working past age 70 . The regression results in Table 8 show that this differential is even greater when controlling for the other variables. Individuals who are worried about health problems expect a slightly lower probability of working after age 70, but this differential is not statistically significant in the regressions. Those who worry more about business conditions in the future, expect a higher chance of working after age 70.

The subjective probability of working after age 70 varies by older workers' current and desired future job features. The most consistent predictor of P70 is the cognitive score of 
individuals' desired future jobs (Table 7). Earlier we saw that people, on average, desire to work in less cognitive jobs compared to their current jobs. But those who desire a smaller decline in the cognitive demands of their future jobs expect to work longer than those who desire a greater decline. An interpretation is that those persons anticipate a more moderate rate of their own cognitive decline, permitting them to hold a more cognitively demanding job.

Current job characteristics are also strong predictors of P70. The two most consistent and statistically significant predictors are flexible work hours and commute times. More flexibility and shorter current commute times are associated with a higher reported chance of working after age 70 .

Labor force status strongly predicts P70: the difference in P70 between part-time employment and full-time self-employment is 19.6 (Table 8). Higher current income reduces P70 while education and self-assessed health have a minor influence. Among the psychological factors, openness to experience is the strongest predictor of P70: those who are more open to new experiences expect to work longer. This is in line with results we found in Hudomiet et al. (2018c) using HRS panel data.

Overall, the strongest predictors of P70 are "worrying about future job demands," the cognitive score of individuals' desired future jobs, commute times, and having flexible work hours. It must be noted that these patterns are correlational and do not necessarily show causal links.

\section{Subjective causal effects of job characteristics on retirement}

To quantify the effect of several specific job characteristics on the timing of retirement we use responses to questions about subjective conditional probabilities. These questions ask individuals about the chance that they would work after age 70 conditional on various factors, 
such as having flexible work hours or less physically demanding jobs. These questions can be used to estimate the subjective causal effect of the factors on retirement by altering the conditioning. The method corresponds to the experiment of altering a characteristic of a job and then observing a change in retirement behavior. The population response would depend on preferences, other job characteristics, economic resources and constraints. For example, a worker with a DB pension focused on a particularly retirement age would be less responsive than a worker with a DC plan. The population average would be the average treatment effect. But our method accommodates analysis of heterogeneity in response because we observed within-person responses. Our approach is related to stated preferences, with the important difference that the probability format of subjective conditional probabilities offers individuals the opportunity to express uncertainty.

\section{The measures}

Apart from minor wording differences, these questions used the following format, with [X] referring to the condition whose effect on retirement we estimated:

$$
\begin{aligned}
& \text { Suppose that [X]. In this case, what are the chances that } \\
& \text { you would be doing any work for pay after you reach age 70? }
\end{aligned}
$$

The conditions were the following:

1. Flexible hours: "...your employer allowed you to flexibly choose

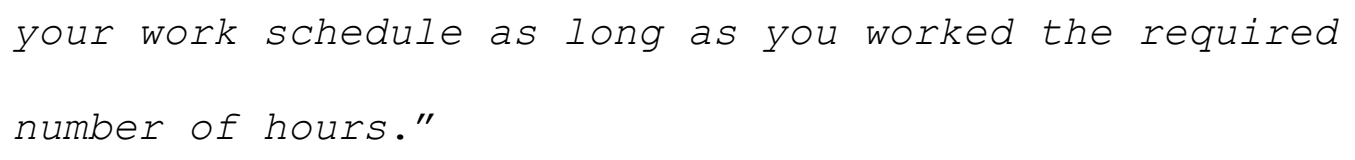

2. Less stress: "...there were jobs available to you that involved little or no stress with the same pay and job demands as your current job." 
3. Less physical: "...there were jobs available to you that required little or no physical effort and offered the same pay as your current job."

4. Self-employed: "...you became self-employed at some point."

5. Short commute: "...there were jobs available to you that were very close to your home with the same pay and job demands as your current job."

6. Telecommute: "...you had the opportunity to work from home either at your current job or at a different job."

7. Less concentration: "...there were jobs available to you that required little concentration and attention with the same pay and job demands as your current job."

8. Part-time: "...you moved into a part-time position at your current employer at some point."

9. Good health: "...when you reach age 70 your health is excellent, very good or good."

10. More wealth: “...you were to inherit $\$ 500,000 . "$

11. Higher wage: "...Congress changed the tax system in a way that all workers above age 70 would bring home $20 \%$ more in wages compared to what they currently make."

12. Longer life: “...scientists discovered a new medicine that added an extra ten years to your life." 
In this paper we are primarily interested in the effect of the job characteristics from (1) to (8), and the other factors (9) to (12) serve as comparisons.

We wanted to ask the questions of the broadest sample possible, but some questions did not apply to those workers who were already experiencing the condition described. For example, (1) was asked only of employees who reported less than $100 \%$ probability that their employer would allow them to flexibly choose their hours (asked earlier in the survey); (4) was only asked of employees who reported less than $100 \%$ probability of ever becoming self-employed; (5) was only asked of workers who commuted at least an hour a day; and (8) was asked only of full-time employees who reported less than $100 \%$ probability that they would switch to a part-time job at their current employer.

To examine question wording effects, we used randomized formats for (10), (11), and (12). The detailed results are reported in Hudomiet et al. (2018b). Here we provide a short summary to explain the sample selection in this paper for the analyses of the respective survey items. We found that the three alternative versions ${ }^{5}$ for question (10) were very similar, so we used them as if they were the same question in this paper. We found, however, that the three alternative versions ${ }^{6}$ of (11) yielded very different response patterns, so here we only used the one that best approximates a causal interpretation (shown in the list above). Two out of three alternatives $^{7}$ of (12) were similar, and therefore we use both here.

\footnotetext{
${ }^{5}$ The second version was similar to the wording we listed above but added an introductory sentence: "Now please think about your situation today, including your current health and financial situation." The third version did not mention inheritance: "Suppose you had $\$ 500,000$ more in financial assets than you do today."

${ }^{6}$ The second version was similar to (11), but further specified that the person's health at age 70 would be excellent, very good, or good. The third version used a more compact wording that did not mention the tax system or the timing of the wage change: "Now imagine that you earned 20\% more than you do now..."

${ }^{7}$ The second version was similar to what we listed above but added the following clarifying clause: "but all other aspects of your life would be unchanged." The third version, which we ignore in this paper, added that the extra 10 years would be healthy years.
} 
For some of the questions we asked about counterfactual conditional probabilities, in which the condition is "turned off." For example, we altered (9) to ask about bad as opposed to good future health. And we sometimes also asked about the probability of the condition. For example, we asked the subjective probability that the person's health would be good at age 70 .

\section{Estimation of the subjective causal effects}

Let $\operatorname{Pr}_{i}\left(W_{70} \mid X\right)$ denote the subjective probability of working conditional on random variable X. X takes the value of 1 if the particular condition is satisfied (e.g., health at age 70 is good), and takes the value of 0 if the condition is not satisfied (e.g., health at age 70 is not good). The subjective causal effect of the condition is then:

$$
\Delta_{i}^{X}=\operatorname{Pr}_{i}\left(W_{70} \mid X=1\right)-\operatorname{Pr}_{i}\left(W_{70} \mid X=0\right)
$$

where $\Delta_{i}^{X}$ denotes the subjective causal effect of X (e.g., good health) on retirement for individual $i$. Then the mean of $\Delta_{i}^{X}$ in the sample is the average subjective causal effect of X on retirement. Because $\Delta_{i}^{X}$ is available on the individual level, we can also use them as left-hand variables of OLS regressions to analyze heterogenous subjective treatment effects.

The simplest way to estimate $\Delta_{i}^{X}$ is by asking two conditional probability questions in the survey (conditioning on the two possible values of $X$ ) and using formula (1). This approach was used only for condition (9) Good health.

We used a slightly modified version for (11) Higher wage. We asked about two conditional probabilities. $\operatorname{Pr}_{i}\left(W_{70} \mid \Delta y=20 \%\right)$ is the subjective probability of working after age 70 conditional on a $20 \%$ wage increase (see wording above), and $\operatorname{Pr}_{i}\left(W_{70} \mid \Delta y=-20 \%\right.$ ) is the 
same probability under the condition that wages go down by $20 \%$. Then the subjective causal effect of a $20 \%$ wage change was defined as

$$
\Delta_{i}^{\text {wage }}=\frac{\operatorname{Pr}_{i}\left(W_{70} \mid \Delta y=20 \%\right)-\operatorname{Pr}_{i}\left(W_{70} \mid \Delta y=-20 \%\right)}{2}
$$

For the rest of the conditions, the counterfactual conditional probabilities (under $X=0$ ) were not available in the survey and had to be approximated. For most cases we replaced them with the unconditional probability of working past age 70, P70. The subjective causal effect was approximated as

$$
\Delta_{i}^{X} \approx \operatorname{Pr}_{i}\left(W_{70} \mid X=1\right)-\operatorname{Pr}_{i}\left(W_{70}\right)
$$

This approximation is valid if the condition (under $X=1$ ) refers to a change from the status quo. For example, the longer life condition in item (12) proposes the discovery of a new drug that is not available and not even discussed in public, and so it seems reasonable to assume that the counterfactual conditional probability equals the unconditional probability, $\operatorname{Pr}_{i}\left(W_{70} \mid X=0\right)=\operatorname{Pr}_{i}\left(W_{70}\right)$. This approach was used for the following conditions: (2) Less stress, (3) Less physical, (5) Shorter commute, (6) Telecommute, (7) Less concentration, (10) More wealth, and (12) Longer life. We worded these questions to refer to a change from the status quo. But it is possible that some individuals did not interpret the question the way we intended. The subjective causal effects reported by these individuals would be biased toward zero, but we expect this bias to be small in the sample.

For the remaining three conditions, (1) Flexible hours, (4) Self-employment, and (8) Parttime, we used survey data on the probability of the condition, denoted by $\operatorname{Pr}_{i}(X=1)$ which was available in the survey. For example, we asked employees about the probability that they will 
ever become self-employed. Then we used the law of total probabilities to estimate the counterfactual conditional probability:

$$
\operatorname{Pr}_{i}\left(W_{70} \mid X=0\right)=\frac{\operatorname{Pr}_{i}\left(W_{70}\right)-\operatorname{Pr}_{i}\left(W_{70} \mid X=1\right) \operatorname{Pr}_{i}(X=1)}{1-\operatorname{Pr}_{i}(X=1)}
$$

The few cases where the estimated probabilities were outside the $[0,1]$ interval were censored at 0 or 1 . Then we entered this estimate into equation (1) to obtain the subjective causal effects.

\section{Results}

Panel A of Table 9 shows the average subjective causal effect of job characteristics, and Panel B shows the effects of health, wealth, earnings, and longevity. Both panels are based on the sample of 50- to 69-year-old workers; and the factors are ordered by effect sizes within the panels. Column 2 shows the average probabilities of working after 70 if the particular condition (e.g., flexible schedule) is not available, and column 3 shows the analogous probability if the condition is available. Then column 4 shows the difference, which is our estimate of the average subjective causal effects of the condition. The values in each row are estimated on the same sample, but the samples across the rows are different due to sample restrictions on some questions, as discussed in Section 3.4.1, and due to item non-response.

Of the 12 factors considered, health has the strongest effect on labor supply. The fraction of those who would work after age 70 would be twice as great if the health of individuals at age 70 were good, very good, or excellent compared to fair or poor $(39.5 \%$ vs. $18.5 \%$, or an increase of 21.0 percentage points). Wealth also has a fairly strong effect on labor supply above age 70 : Inheriting $\$ 500,000$ would reduce labor supply by 16.2 percentage points, from $32.6 \%$ to $16.4 \%$. These elasticities are large, but they are in line with other findings in the literature showing that 
labor supply elasticities increase with age as individuals get closer to the margin of leaving the labor force (Blundell, French \& Tetlow, 2016). The rest of the factors in Panel B have somewhat smaller effects. A $20 \%$ increase in wages would increase labor supply after age 70 by 10.1 percentage points, and an extra 10 years longevity would increase labor supply by only 1.4 percentage points.

With respect to working conditions, we found that working in jobs that permit flexible hours had the largest subjective causal effect on average. According to our estimates it would increase the subjective probability of working after age 70 by 15 percentage points on a base of $17.2 \%$. This effect is similar to the effect of inheriting $\$ 500,000$, and considerably larger than a $20 \%$ increase in take-home pay. Flexible hours, thus, seem to be very important to older individuals.

The stress level of the jobs, physical demands, and ability to become self-employed also show large effects. Each of these factors would increase labor supply by more than 10 percentage points, or roughly the same as a $20 \%$ increase in wages. Short commuting time (estimated on the sample that commutes at least an hour a day), having the option to telecommute, and having a job that does not require concentration had slightly lower effects of about 8-9 percentage points. Switching to a part-time job at an individual's current employer would not affect labor supply by much.

Next, we investigated the heterogeneity in the subjective casual effects of selected conditions by observable factors. To that end we regressed the individual-level subjective causal effects on individual characteristics. The OLS regression coefficients are shown in Table 10. The interpretation of a coefficient is the additional causal effect among those with the characteristic compared with those not having the characteristic. For example, among those who 
say that health problems will likely be an important factor limiting their ability to work, the subjective causal effect on P70 of having a flexible schedule is 6.4 percentage points greater than among those where health is not perceived to be an important factor. An interpretation is that having flexibility to manage health problems permits later retirement among those who anticipate having work-limiting health problems. Flexibility is less important among those who do not anticipate having health problems. We note that this interpretation provides an explanation for the strong desire to have flexibility on the job.

The results suggest that the labor supply of workers who worry about the demands of the job tends to be more responsive to many job characteristics: the subjective causal effects of jobstress, physical requirements, self-employment, and concentration are all significantly higher in this group, as evidenced by the positive and statistically significant coefficients in the "Job demands" row. For example, consider those concerned about whether the demands of the job would permit them to work to age 70. If the job were not stressful rather than stressful, P70 would increase by 7.8 percentage points more than it would among those not concerned about the demands of the job. Reference to Table 8 shows that P70 is reduced by 9.0 percentage points when job demands are perceived to be important, so that the elimination of job stress would approximately eliminate the difference between those concerned about the demands of the job and those not concerned.

Individuals' current job features (second panel) do not seem to affect their subjective causal effects by much. The only statistically significant coefficient is on the social index: the labor supply of workers in more social jobs are less affected by having flexible schedules. 
Interestingly, the labor supply of those individuals who are allowed to telecommute was significantly less responsive to working conditions compared to those who are not allowed to work from home. Perhaps their jobs are already flexible, not stressful, not physical and so forth.

With respect to demographic predictors, we found weak gender differences in the causal effects of the different job characteristics, while the differences by education were more pronounced, suggesting highly educated individuals' labor supply may be more sensitive to stress, physical requirements, and concentration. The labor supply of individuals in bad health tends to be less responsive to job characteristics, likely because it is more difficult for them to work in any jobs. High-income individuals' labor supply is less responsive to work-stress and the level of required concentration, which may mean that they are better at coping with such challenges.

Current labor market status is a weak predictor of subjective causal effects. Compared to full-time employees, part-time employees care more about being self-employed and having jobs that require little concentration, but care less about the option to telecommute. Self-employed people have similar causal effects to full-time employees.

The psychological factors predict the subjective causal effects less strongly. We see some evidence that those who score higher on the number series test (i.e., the cognitively more able) care more about the option to telecommute, similar to more neurotic and more agreeable individuals and those who are more open to new experiences. Having jobs that require little concentration has a significantly higher effect on the labor supply of the more extroverted respondents, and significantly smaller effect on more individuals with higher scores for openness. 
Appendix Tables B7 and B8 investigate some methodological properties of conditional subjective probabilities. Table B7 shows the fraction of the sample whose responses reflect a "corner solution" of $0 \%$ or $100 \%$ limiting the size of the subjective causal effects. We found that a small, but non-negligible fraction of the sample would never work after age $70(\mathrm{P} 70=0)$ independently of the values of the conditions. For example, $15 \%$ report P70 $=0$ when the job is posited to be not stressful. It is less frequent that individuals are sure to work after age 70 (P70 $=$ 100).

An interesting additional result in Table B7 is that more than $60 \%$ of individuals say that they would surely not work after age 70 (i.e. the probability of work would be $0 \%$ ) if they did not have flexible work hours. This is by far the strongest predictor of this outcome.

In Table B8 we investigated the fraction of the sample with $0 \%$ causal effects vs. positive or negative effects. We found that about a third of the sample are not responsive to the conditions, and about $2-31 \%$ of the sample (depending on the condition) gave answers that were in the wrong direction; that is, P70 decreased when a desirable condition was assumed. People gave the least consistent answers to the longevity question.

\section{Conclusion}

The decision about when and how to retire can be complex for many workers. Many factors influence this choice such as workers' health, abilities, and preferences for job characteristics and leisure activities, as well as employers' demands, government regulations, and other institutional factors. Prior literature found large heterogeneity in the way people transition from work to full retirement. Some retire early, others retire late, some retire directly 
from full-time jobs, and others take a more gradual pathway through part-time work or selfemployment before completely leaving the labor force.

Using a newly designed survey of over 2,000 individuals age 50 to 79 , this paper explored the role of workers' preferences for job characteristics and for retirement pathways so as to understand their role in the retirement process. Our survey included questions about four related sets of outcome variables: (1) workers' ratings of alternative work-to-retirement pathways; (2) workers' current and desired job characteristics; (3) subjective probabilities of working after age 70; and (4) workers' subjective conditional probabilities of working after age 70 if certain job characteristics were available to them. We presented cross-tabulations between these outcome variables and covariates of interest, such as gender and labor force status, and OLS regressions with a rich set of predictor variables.

We found that the traditional retirement paths (i.e., retiring directly and completely from full-time jobs) were by far the most frequently preferred work-to-retirement pathways: About half of the sample indicated a preference to retire this way. We also found large heterogeneity in workers' preferences, with many indicating more-gradual pathways as one of their preferred choices: almost a quarter of the sample expressed a preference for first taking part-time jobs; $8 \%$ preferred a period of self-employment before retirement; and a little over 10\% preferred working forever. Females were somewhat more likely to prefer the gradual pathways through part-time jobs and self-employment, and they were less likely to prefer never retiring. Part-time employees and self-employed workers were more likely than full-time employees to prefer the gradual pathways. We also found differences by education, health, and psychological factors, such as cognitive abilities, and workers' Big 5 personality traits. Standard economic theory ignores 
psychological factors, but our results suggest that they may be useful to understand heterogeneity in the population that is not explained by standard economic variables.

We found that most workers were worried about health and the demands of their jobs when considering their prospects of working longer. At the same time, relatively few workers worried that their employers would not allow them to stay at the firm.

When looking at older workers' current and desired job features, we found that most people would like to move to a less cognitively and less physically demanding job compared to their current one, while they would prefer jobs with more social opportunities, with more comfortable temperatures, and with more flexible schedules. We also found large differences in preferences by gender, labor force status, income, and psychological factors.

We found that less than half of older workers reported that they could flexibly choose their work hours, could switch to a part-time position, or telecommute. These favorable working conditions are far from universal, among older workers in the U.S.

When we analyzed the subjective probabilities of working after age 70, we found that the strongest predictors were "worrying about future job demands," the cognitive score of individuals' desired future jobs, commute times, and whether the worker has flexible work hours.

We analyzed the subjective causal effects of working conditions on working past age 70. We found that flexible work hours had the largest effect, which would increase the subjective probability of working after age 70 by 15 percentage points on a base of about $17 \%$, thus having a larger effect than a $20 \%$ increase in wages. Work stress, the physical demands of jobs, the opportunity to become self-employed, short commuting time, and having the option to telecommute were also relatively important, in this order. Switching to a part-time job at an individual's current employer would not affect labor supply much. These findings suggest that 
policies that increase older workers' abilities to choose their work hours more flexibly may have the largest impact on delaying their retirement. At the same time, the option to take part-time jobs, which is often argued to be more suitable for older workers, does not seem to have large effects on individuals' retirement expectations.

Overall, having flexible work hours and having short commutes were the factors that consistently came out as important determinants of retirement across most of our models. Moreover, demands of the jobs, especially the cognitive demands of individuals' future jobs as well as stress, were also strong predictors of retirement.

In interpreting these findings, it is important to keep in mind that they are based on observational data, and that the outcome variables were stated preferences, as opposed to workers' observed behavior. The external validity of such stated preference measures is not guaranteed. It would be interesting for future research to complement our approach with other methodologies that identify workers' preferences from their choices, such as their subsequent realized retirement pathways that could be observed in longitudinal data. Furthermore, there are several alternative mechanisms that can explain the identified patterns. For example, we found that the psychological factors were predictors of preferences for different retirement pathways and desired job features even after controlling for traditional socio-economic variables. Cognitive abilities and personality traits may affect individuals' preferences for leisure activities, or the disutility from carrying out difficult tasks at work; and they may also correlate with certain personal or baseline job characteristics that we did not observe in our data. It would be interesting to explore in future research the mechanisms that are responsible for the patterns we found. 
We documented large heterogeneity in workers' preferences for job characteristics preceding retirement and for retirement pathways, and some of this heterogeneity was explained by observable characteristics, such as health, current job characteristics, cognitive ability, or personality traits. These heterogeneities imply that there is no one job type that fits all older workers' desires. The differences between workers' current job attributes and the ones they desire for their jobs preceding retirement suggest that increased flexibility from either adjusting tasks on the job or changing jobs would help workers realize their preferences. In some cases, institutional factors limit that flexibility. For example, workers with a defined benefit pension plan usually cannot transfer those benefits to another job. According to our results, the largest impact on delaying workers' retirement may be achieved by allowing older workers to choose their work hours more flexibly. This is rather starkly brought out by our estimate that $60 \%$ of our sample would surely not work at age $70(\mathrm{P} 70=0)$ if their jobs provided no hours flexibility. 
Tables

Table 1. Descriptive statistics about the analytic sample

\begin{tabular}{|c|c|c|c|c|c|}
\hline & & \multicolumn{2}{|c|}{ Unweighted } & \multicolumn{2}{|c|}{ Weighted } \\
\hline & & mean & $\mathrm{sd}$ & mean & $\mathrm{sd}$ \\
\hline Female & 2,177 & 0.538 & 0.499 & 0.503 & 0.500 \\
\hline Age & 2,177 & 63.04 & 7.53 & 58.36 & 7.01 \\
\hline Non-Hispanic white & 2,177 & 0.819 & 0.385 & 0.673 & 0.469 \\
\hline Non-Hispanic black & 2,177 & 0.071 & 0.256 & 0.108 & 0.311 \\
\hline Non-Hispanic, other race & 2,177 & 0.033 & 0.178 & 0.056 & 0.230 \\
\hline Hispanic & 2,177 & 0.078 & 0.268 & 0.163 & 0.369 \\
\hline High school or less & 2,177 & 0.146 & 0.353 & 0.356 & 0.479 \\
\hline Some college & 2,177 & 0.356 & 0.479 & 0.276 & 0.447 \\
\hline College or more & 2,177 & 0.497 & 0.500 & 0.368 & 0.483 \\
\hline Married & 2,177 & 0.623 & 0.485 & 0.676 & 0.468 \\
\hline Divorced/separated & 2,177 & 0.200 & 0.400 & 0.183 & 0.387 \\
\hline Widowed & 2,177 & 0.079 & 0.269 & 0.048 & 0.213 \\
\hline Never married & 2,177 & 0.098 & 0.298 & 0.093 & 0.291 \\
\hline Health excellent & 2,177 & 0.115 & 0.319 & 0.106 & 0.308 \\
\hline Health very good & 2,177 & 0.406 & 0.491 & 0.393 & 0.489 \\
\hline Health good & 2,177 & 0.317 & 0.466 & 0.341 & 0.474 \\
\hline Health fair & 2,177 & 0.122 & 0.328 & 0.120 & 0.325 \\
\hline Health poor & 2,177 & 0.040 & 0.195 & 0.040 & 0.195 \\
\hline Log family income & 2,177 & 10.98 & 0.85 & 10.99 & 0.90 \\
\hline Full-time employee & 2,177 & 0.345 & 0.475 & 0.477 & 0.500 \\
\hline Part-time employee & 2,177 & 0.130 & 0.336 & 0.128 & 0.334 \\
\hline Full-time self-employed & 2,177 & 0.051 & 0.220 & 0.058 & 0.234 \\
\hline Part-time self-employed & 2,177 & 0.066 & 0.248 & 0.045 & 0.208 \\
\hline Not working & 2,177 & 0.408 & 0.492 & 0.291 & 0.454 \\
\hline Cognitive job (current job) & 1,288 & 0.679 & 0.227 & 0.670 & 0.225 \\
\hline Cognitive job (last job) & 889 & 0.709 & 0.230 & 0.674 & 0.231 \\
\hline Physical job (current job) & 1,288 & 0.282 & 0.315 & 0.348 & 0.344 \\
\hline Physical job (last job) & 889 & 0.308 & 0.336 & 0.400 & 0.373 \\
\hline Social job (current job) & 1,288 & 0.682 & 0.207 & 0.687 & 0.206 \\
\hline Social job (last job) & 889 & 0.692 & 0.212 & 0.679 & 0.215 \\
\hline Number series score & 2,177 & 0.000 & 1.000 & -0.081 & 1.032 \\
\hline Neuroticism & 2,177 & 0.000 & 1.000 & 0.045 & 1.005 \\
\hline Extroversion & 2,177 & 0.000 & 1.000 & 0.022 & 0.995 \\
\hline Agreeableness & 2,177 & 0.000 & 1.000 & 0.002 & 1.012 \\
\hline Conscientiousness & 2,177 & 0.000 & 1.000 & -0.047 & 1.012 \\
\hline Openness & 2,177 & 0.000 & 1.000 & -0.074 & 1.029 \\
\hline
\end{tabular}


Table 2. Preferred work-to-retirement pathways by gender and labor force status

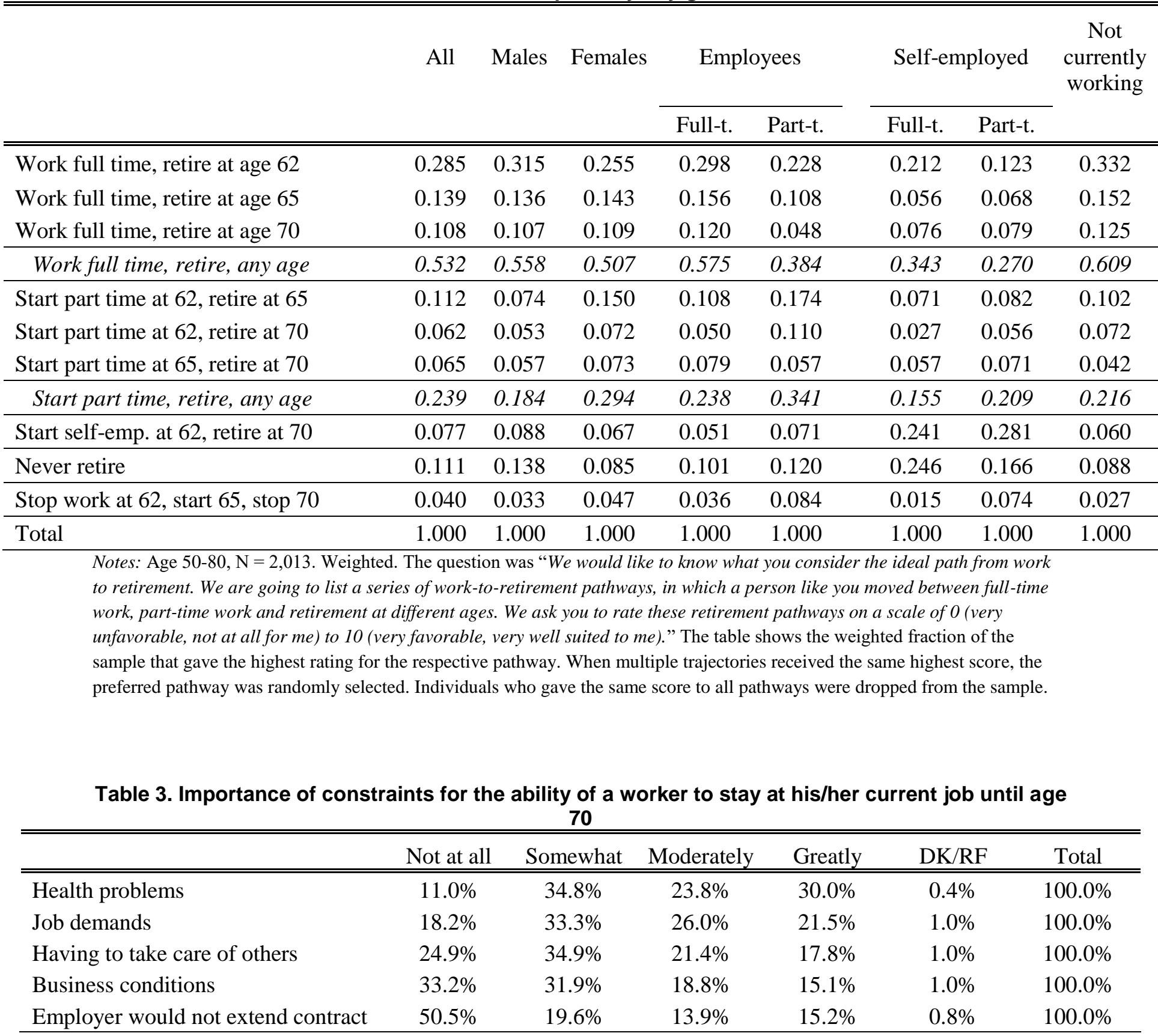

Notes: Age 50-69, working for pay, $\mathrm{N}=1,160$. Weighted. The question was " $[\ldots]$ assume that you wanted to continue working at your current/main job until age 70. Do you think the following factors would limit your ability to continue working at your [current/main] job until retiring completely?" 
Table 4. Current and desired future job features by gender

\begin{tabular}{|c|c|c|c|c|c|c|}
\hline & \multicolumn{2}{|c|}{ Total sample } & \multicolumn{2}{|c|}{ Males } & \multicolumn{2}{|c|}{ Females } \\
\hline & $\begin{array}{c}\text { current } \\
\text { job }\end{array}$ & $\begin{array}{c}\text { future } \\
\text { job }\end{array}$ & $\begin{array}{c}\text { current } \\
\text { job }\end{array}$ & $\begin{array}{c}\text { future } \\
\text { job }\end{array}$ & $\begin{array}{c}\text { current } \\
\text { job }\end{array}$ & $\begin{array}{c}\text { future } \\
\text { job }\end{array}$ \\
\hline \multicolumn{7}{|l|}{ Cognitive job features } \\
\hline Monitor information & 0.746 & 0.516 & 0.766 & 0.546 & 0.725 & 0.484 \\
\hline Thinking & 0.749 & 0.558 & 0.755 & 0.604 & 0.741 & 0.509 \\
\hline Variety of skills & 0.802 & 0.659 & 0.823 & 0.685 & 0.781 & 0.631 \\
\hline High level skills & 0.598 & 0.503 & 0.645 & 0.552 & 0.548 & 0.450 \\
\hline Not simple tasks & 0.585 & 0.423 & 0.601 & 0.461 & 0.567 & 0.382 \\
\hline Solve problems & 0.539 & 0.577 & 0.560 & 0.587 & 0.517 & 0.567 \\
\hline Average cognitive & 0.670 & $\mathbf{0 . 5 3 9}$ & 0.692 & 0.572 & 0.647 & $\mathbf{0 . 5 0 4}$ \\
\hline \multicolumn{7}{|l|}{ Physical job features } \\
\hline Muscular strength & 0.307 & 0.141 & 0.352 & 0.167 & 0.259 & 0.114 \\
\hline Physical effort & 0.389 & 0.211 & 0.448 & 0.257 & 0.327 & 0.163 \\
\hline Average physical & 0.348 & $\mathbf{0 . 1 7 6}$ & 0.400 & 0.212 & 0.293 & $\mathbf{0 . 1 3 9}$ \\
\hline \multicolumn{7}{|l|}{ Social job features } \\
\hline Coworkers friendly & 0.759 & 0.854 & 0.752 & 0.842 & 0.766 & 0.866 \\
\hline Can get to know other people & 0.801 & 0.758 & 0.817 & 0.711 & 0.784 & 0.808 \\
\hline Can develop friendships & 0.599 & 0.634 & 0.570 & 0.621 & 0.630 & 0.648 \\
\hline Coworkers take personal interest & 0.588 & 0.615 & 0.568 & 0.599 & 0.609 & 0.633 \\
\hline Average social & 0.687 & 0.715 & 0.677 & 0.693 & 0.697 & $\mathbf{0 . 7 3 9}$ \\
\hline \multicolumn{7}{|l|}{ Other job features } \\
\hline Comfortable temperature & 0.660 & 0.770 & 0.629 & 0.749 & 0.692 & 0.792 \\
\hline Flexible schedule & 0.558 & 0.687 & 0.573 & 0.685 & 0.542 & 0.689 \\
\hline
\end{tabular}

Notes: Age 50-80, working for pay, $\mathrm{N}=1,288$. Weighted. The wording of the question about workers' current job was “We would like to learn about your [current/main job]. Does it have any of the following [requirements/features]?" The wording of the question about workers' future job was "Please continue to assume that you would be looking for a new job sometime [after age 60/in the future]. Do you think the job you would look for at that time would have any of the following

[requirements/features]?" The answer options were: (1) Absolutely yes, (2) Partly yes/partly no, (3) Absolutely no, or (4) It did not matter to me (for some questions). These responses were coded into a 0 to 1 scale: "absolutely no" answers were coded as zero; "partly yes/partly no," "it did not matter to me," and missing answers were coded as 0.5 , and "absolutely yes" answers were coded as 1 . 
Table 5. Current and desired future job features by labor force status

\begin{tabular}{|c|c|c|c|c|c|c|}
\hline & \multicolumn{2}{|c|}{ Full-time employees } & \multicolumn{2}{|c|}{ Part-time employees } & \multicolumn{2}{|c|}{ Self-employed } \\
\hline & $\begin{array}{c}\text { current } \\
\text { job }\end{array}$ & $\begin{array}{c}\text { future } \\
\text { job }\end{array}$ & $\begin{array}{c}\text { current } \\
\text { job }\end{array}$ & $\begin{array}{c}\text { future } \\
\text { job }\end{array}$ & $\begin{array}{c}\text { current } \\
\text { job }\end{array}$ & $\begin{array}{l}\text { future } \\
\text { job }\end{array}$ \\
\hline \multicolumn{7}{|l|}{ Cognitive job features } \\
\hline Monitor information & 0.813 & 0.543 & 0.581 & 0.458 & 0.641 & 0.465 \\
\hline Thinking & 0.795 & 0.581 & 0.614 & 0.477 & 0.698 & 0.549 \\
\hline Variety of skills & 0.841 & 0.681 & 0.660 & 0.575 & 0.800 & 0.659 \\
\hline High level skills & 0.646 & 0.527 & 0.446 & 0.426 & 0.564 & 0.486 \\
\hline Not simple tasks & 0.633 & 0.435 & 0.407 & 0.355 & 0.581 & 0.449 \\
\hline Solve problems & 0.545 & 0.575 & 0.523 & 0.586 & 0.534 & 0.576 \\
\hline Average cognitive & 0.712 & $\mathbf{0 . 5 5 7}$ & 0.538 & 0.480 & 0.636 & 0.531 \\
\hline \multicolumn{7}{|l|}{ Physical job features } \\
\hline Muscular strength & 0.298 & 0.138 & 0.320 & 0.139 & 0.332 & 0.157 \\
\hline Physical effort & 0.366 & 0.202 & 0.449 & 0.198 & 0.421 & 0.269 \\
\hline Average physical & 0.332 & 0.170 & 0.385 & 0.169 & $\mathbf{0 . 3 7 7}$ & 0.213 \\
\hline \multicolumn{7}{|l|}{ Social job features } \\
\hline Coworkers friendly & 0.756 & 0.847 & 0.763 & 0.877 & 0.764 & 0.859 \\
\hline Can get to know other people & 0.820 & 0.745 & 0.761 & 0.813 & 0.763 & 0.752 \\
\hline Can develop friendships & 0.611 & 0.619 & 0.595 & 0.683 & 0.548 & 0.644 \\
\hline Coworkers take personal interest & 0.574 & 0.605 & 0.604 & 0.636 & 0.633 & 0.640 \\
\hline Average social & 0.690 & 0.704 & 0.681 & 0.752 & 0.677 & $\mathbf{0 . 7 2 3}$ \\
\hline \multicolumn{7}{|l|}{ Other job features } \\
\hline Comfortable temperature & 0.660 & 0.771 & 0.669 & 0.779 & 0.648 & 0.750 \\
\hline Flexible schedule & 0.507 & 0.665 & 0.499 & 0.660 & 0.867 & 0.817 \\
\hline
\end{tabular}


Table 6. Availability of certain job characteristics for older workers

\begin{tabular}{|c|c|c|c|c|}
\hline & \multicolumn{2}{|c|}{$\begin{array}{l}\text { Probability that the } \\
\text { employer would... }\end{array}$} & \multicolumn{2}{|c|}{ At the workers' current job } \\
\hline & $\begin{array}{c}\text {...allow } \\
\text { part-time } \\
\text { work }\end{array}$ & $\begin{array}{c}\text {...allow } \\
\text { flexible } \\
\text { work hours } \\
\end{array}$ & $\begin{array}{c}\text { Fraction with } \\
\text { possibility to } \\
\text { work from home }\end{array}$ & $\begin{array}{c}\text { Daily total } \\
\text { commute time } \\
\text { in minutes } \\
\end{array}$ \\
\hline Total sample & 40.7 & 39.8 & 0.431 & 64.9 \\
\hline Males & 35.8 & 36.8 & 0.412 & 65.0 \\
\hline Females & 47.0 & 43.1 & 0.452 & 64.8 \\
\hline Full-time employees & 40.7 & 36.0 & 0.381 & 64.6 \\
\hline Part-time employees & - & 56.2 & 0.322 & 74.2 \\
\hline Full-time self-employed & - & - & 0.794 & 62.7 \\
\hline Part-time self-employed & - & - & 0.870 & 44.3 \\
\hline Number of valid answers & 647 & 866 & 1158 & 1154 \\
\hline
\end{tabular}

Table 7. Mean subjective probability of working after age 70 by job constraints, job features and job characteristics

\begin{tabular}{|c|c|c|c|}
\hline & [1] & [2] & [3] \\
\hline A. Importance of job constraints & not important & important & difference \\
\hline Health problems & 34.6 & 31.7 & -2.9 \\
\hline Caretaking & 33.5 & 32.6 & -0.8 \\
\hline Job demands & 36.7 & 28.8 & -7.9 \\
\hline Employer willingness & 33.4 & 32.5 & -0.8 \\
\hline Business conditions & 32.3 & 34.6 & 2.3 \\
\hline B. Current and future job features & below median & above median & difference \\
\hline Future job cognitive score & 30.6 & 35.7 & 5.1 \\
\hline Current job cognitive score & 31.9 & 34.9 & 3.0 \\
\hline Future job physical score & 33.0 & 33.0 & 0.0 \\
\hline Current job physical score & 32.5 & 33.6 & 1.1 \\
\hline Future job social score & 30.9 & 37.7 & 6.8 \\
\hline Current job social score & 32.0 & 35.2 & 3.1 \\
\hline C. Availability of job characteristics & below median & above median & difference \\
\hline $\begin{array}{l}\text { Employer would allow part-time } \\
\text { Employer would allow flexible }\end{array}$ & 31.3 & 35.4 & 4.1 \\
\hline \multirow[t]{2}{*}{ hours } & 29.0 & 35.6 & 6.6 \\
\hline & no & yes & difference \\
\hline Can work from home & 31.2 & 35.4 & 4.2 \\
\hline Commute less than 60 min a day & 29.8 & 35.1 & 5.3 \\
\hline
\end{tabular}




\begin{tabular}{|c|c|c|c|c|c|}
\hline & {$[1]$} & {$[2]$} & [3] & {$[4]$} & [5] \\
\hline \multicolumn{6}{|l|}{$\begin{array}{l}\text { Following job constraints will be } \\
\text { important }\end{array}$} \\
\hline Health problems & & $\begin{array}{l}-2.086 \\
{[2.071]}\end{array}$ & & & $\begin{array}{l}-1.688 \\
{[2.066]}\end{array}$ \\
\hline Caretaking & & $\begin{array}{l}3.338 \\
{[2.158]}\end{array}$ & & & $\begin{array}{c}3.592 \\
{[2.140]^{*}}\end{array}$ \\
\hline Job demands & & $\begin{array}{c}-8.976 \\
{[2.035]^{* * *}}\end{array}$ & & & $\begin{array}{c}-9.523 \\
{[2.074]^{* * *}}\end{array}$ \\
\hline Employer willingness & & $\begin{array}{l}-0.064 \\
{[2.364]}\end{array}$ & & & $\begin{array}{l}1.216 \\
{[2.377]}\end{array}$ \\
\hline Business conditions & & $\begin{array}{c}4.603 \\
{[2.275]^{* *}}\end{array}$ & & & $\begin{array}{c}5.933 \\
{[2.282]^{* * *}}\end{array}$ \\
\hline \multicolumn{6}{|l|}{ Current and future job features } \\
\hline Future job cognitive score & & & $\begin{array}{c}24.119 \\
{[5.091]^{* * *}}\end{array}$ & & $\begin{array}{c}22.159 \\
{[5.094]^{* * *}}\end{array}$ \\
\hline Current job cognitive score & & & $\begin{array}{l}-5.868 \\
{[4.937]}\end{array}$ & & $\begin{array}{c}-1.893 \\
{[4.938]}\end{array}$ \\
\hline Future job physical score & & & $\begin{array}{l}-6.212 \\
{[4.431]}\end{array}$ & & $\begin{array}{l}-8.426 \\
{[4.380]^{*}}\end{array}$ \\
\hline Current job physical score & & & $\begin{array}{l}4.367 \\
{[3.260]}\end{array}$ & & $\begin{array}{c}7.954 \\
{[3.355]^{* *}}\end{array}$ \\
\hline Future job social score & & & $\begin{array}{l}7.186 \\
{[5.336]}\end{array}$ & & $\begin{array}{c}7.253 \\
{[5.258]}\end{array}$ \\
\hline Current job social score & & & $\begin{array}{r}4.819 \\
{[5.077]} \\
\end{array}$ & & $\begin{array}{l}1.936 \\
{[5.041]} \\
\end{array}$ \\
\hline \multicolumn{6}{|l|}{ Availability of job characteristics } \\
\hline Employer would allow part-time & & & & $\begin{array}{l}0.049 \\
{[0.033]}\end{array}$ & $\begin{array}{c}0.06 \\
{[0.033]^{*}}\end{array}$ \\
\hline Employer would allow flexible hours & & & & $\begin{array}{c}0.084 \\
{[0.031]^{* * *}}\end{array}$ & $\begin{array}{c}0.077 \\
{[0.031]^{* *}}\end{array}$ \\
\hline Can work from home & & & & $\begin{array}{l}2.281 \\
{[2.067]}\end{array}$ & $\begin{array}{l}-0.647 \\
{[2.133]}\end{array}$ \\
\hline Commute less than 60 min a day & & & & $\begin{array}{c}5.123 \\
{[1.862]^{* * *}}\end{array}$ & $\begin{array}{c}5.323 \\
{[1.847]^{* * *}}\end{array}$ \\
\hline Female & $\begin{array}{c}-5.181 \\
{[1.977]^{* * *}}\end{array}$ & $\begin{array}{c}-5.391 \\
{[1.974]^{* * * *}}\end{array}$ & $\begin{array}{l}-3.929 \\
{[2.037]^{*}}\end{array}$ & $\begin{array}{c}-5.584 \\
{[1.971]^{* * * *}}\end{array}$ & $\begin{array}{c}-4.048 \\
{[2.032]^{* *}} \\
\end{array}$ \\
\hline High school or less & ref. & ref. & ref. & ref. & ref. \\
\hline Some college & $\begin{array}{c}2.2 \\
{[2.451]}\end{array}$ & $\begin{array}{l}1.874 \\
{[2.427]}\end{array}$ & $\begin{array}{l}0.818 \\
{[2.482]}\end{array}$ & $\begin{array}{l}1.565 \\
{[2.437]}\end{array}$ & $\begin{array}{l}0.421 \\
{[2.439]}\end{array}$ \\
\hline College or more & $\begin{array}{c}4.269 \\
{[2.476]^{*}}\end{array}$ & $\begin{array}{l}3.411 \\
{[2.460]}\end{array}$ & $\begin{array}{l}1.847 \\
{[2.653]}\end{array}$ & $\begin{array}{l}3.478 \\
{[2.474]}\end{array}$ & $\begin{array}{l}0.997 \\
{[2.615]}\end{array}$ \\
\hline Health excellent & $\begin{array}{l}0.236 \\
{[3.160]}\end{array}$ & $\begin{array}{l}0.399 \\
{[3.127]}\end{array}$ & $\begin{array}{l}0.478 \\
{[3.140]}\end{array}$ & $\begin{array}{l}-0.448 \\
{[3.135]}\end{array}$ & $\begin{array}{l}0.073 \\
{[3.086]}\end{array}$ \\
\hline Health very good & $\begin{array}{l}3.007 \\
{[2.076]}\end{array}$ & $\begin{array}{c}2.99 \\
{[2.058]}\end{array}$ & $\begin{array}{c}3.4 \\
{[2.068]}\end{array}$ & $\begin{array}{l}2.999 \\
{[2.063]}\end{array}$ & $\begin{array}{c}3.707 \\
{[2.040]^{*}}\end{array}$ \\
\hline
\end{tabular}




\begin{tabular}{|c|c|c|c|c|c|}
\hline Health good & ref. & ref. & ref. & ref. & ref. \\
\hline \multirow[t]{2}{*}{ Health fair } & -0.153 & -0.516 & 0.379 & 0.021 & 0.101 \\
\hline & {$[3.611]$} & [3.599] & [3.593] & {$[3.618]$} & {$[3.580]$} \\
\hline \multirow[t]{2}{*}{ Health poor } & 1.238 & 3.223 & 2.215 & -1.035 & 2.346 \\
\hline & [7.893] & [7.886] & [7.850] & [7.828] & [7.795] \\
\hline \multirow[t]{2}{*}{ Log family income } & -7.554 & -7.567 & -7.328 & -8.072 & -7.086 \\
\hline & {$[1.453]^{* * *}$} & {$[1.448] * * *$} & {$[1.504] * * *$} & {$[1.471]^{* * * *}$} & {$[1.511]^{* * *}$} \\
\hline Full-time employee & ref. & ref. & ref. & ref. & ref. \\
\hline \multirow[t]{2}{*}{ Part-time employee } & -10.275 & -9.747 & -9.971 & -12.089 & -10.772 \\
\hline & {$[2.728]^{* * *}$} & {$[2.708]^{* * *}$} & {$[2.768]^{* * *}$} & {$[2.752]^{* * *}$} & {$[2.760]^{* * *}$} \\
\hline \multirow[t]{2}{*}{ Full-time self-employed } & 9.331 & 8.946 & 9.847 & 6.936 & 8.466 \\
\hline & {$[3.423]^{* * *}$} & {$[3.430]^{* * *}$} & {$[3.439]^{* * *}$} & {$[3.502]^{* *}$} & {$[3.551]^{* *}$} \\
\hline \multirow[t]{2}{*}{ Part-time self-employed } & -2.179 & -2.335 & -2.361 & -4.102 & -2.51 \\
\hline & {$[3.966]$} & {$[3.936]$} & [3.959] & [4.059] & [4.042] \\
\hline \multirow[t]{2}{*}{ Number series score } & 1.757 & 2.197 & 1.41 & 1.724 & 1.811 \\
\hline & {$[1.029]^{*}$} & {$[1.021]^{* *}$} & [1.026] & {$[1.023]^{*}$} & {$[1.015]^{*}$} \\
\hline \multirow[t]{2}{*}{ Neuroticism } & -0.286 & -0.23 & -0.118 & -0.085 & -0.046 \\
\hline & [0.969] & [0.966] & [0.976] & {$[0.963]$} & {$[0.969]$} \\
\hline \multirow[t]{2}{*}{ Extroversion } & -1.052 & -0.937 & -1.527 & -1.358 & -1.989 \\
\hline & {$[1.202]$} & [1.190] & [1.223] & [1.199] & {$[1.204]^{*}$} \\
\hline \multirow[t]{2}{*}{ Agreeableness } & 1.919 & 1.507 & 1.67 & 1.959 & 1.299 \\
\hline & {$[1.103]^{*}$} & [1.099] & [1.115] & {$[1.092]^{*}$} & [1.101] \\
\hline \multirow{2}{*}{ Conscientiousness } & -2.335 & -2.273 & -2.278 & -2.229 & -2.058 \\
\hline & {$[1.037]^{* *}$} & {$[1.028]^{* *}$} & {$[1.035]^{* *}$} & {$[1.027]^{* *}$} & {$[1.020]^{* *}$} \\
\hline \multirow[t]{2}{*}{ Openness } & 3.371 & 3.356 & 2.305 & 3.157 & 2.216 \\
\hline & {$[1.081]^{* * *}$} & {$[1.078] * * *$} & {$[1.111]^{* *}$} & {$[1.082] * * *$} & {$[1.100]^{* *}$} \\
\hline \multirow[t]{2}{*}{ Constant } & 117.631 & 121.046 & 97.185 & 115.336 & 87.948 \\
\hline & $\begin{array}{c}{[16.280]^{* *}} \\
*\end{array}$ & $\begin{array}{c}{[16.396]^{* *}} \\
*\end{array}$ & $\begin{array}{c}{[17.515]^{* *}} \\
*\end{array}$ & $\begin{array}{c}{[16.547]^{* *}} \\
*\end{array}$ & $\begin{array}{c}{[17.821]^{* *}} \\
*\end{array}$ \\
\hline Age, race, marital status controls & YES & YES & YES & YES & YES \\
\hline R-squared & 0.131 & 0.155 & 0.155 & 0.152 & 0.197 \\
\hline
\end{tabular}


Table 9. Subjective causal effect on P70 of job characteristics and other factors

\begin{tabular}{|c|c|c|c|c|}
\hline & \multirow[b]{2}{*}{$\mathrm{N}$} & \multicolumn{2}{|c|}{ Probability of working past age 70} & \multirow[b]{2}{*}{$\begin{array}{c}\text { Subjective } \\
\text { causal effect } \\
([3]-[2])\end{array}$} \\
\hline & & $\begin{array}{l}\text { Without } \\
\text { condition }\end{array}$ & $\begin{array}{c}\text { With } \\
\text { condition }\end{array}$ & \\
\hline Panel A: Job characteristics & {$[1]$} & [2] & [3] & [4] \\
\hline A.1. Employer offers flexible schedule & 656 & 17.2 & 32.2 & 15.0 \\
\hline A.2. Job not stressful & 990 & 33.4 & 44.6 & 11.2 \\
\hline A.3. Job requires no physical effort & 975 & 33.3 & 44.3 & 11.0 \\
\hline A.4. Become self-employed & 712 & 27.7 & 38.5 & 10.8 \\
\hline A.5. Short commute & 243 & 29.3 & 38.3 & 9.1 \\
\hline A.6. Work from home & 989 & 30.5 & 39.3 & 8.9 \\
\hline A.7. Job requires no concentration & 972 & 33.4 & 41.4 & 8.0 \\
\hline A.8. Switch to part-time at current emp. & 543 & 31.4 & 35.6 & 4.2 \\
\hline \multicolumn{5}{|l|}{ Panel B: Other factors } \\
\hline B.1. Health: good or better & 1018 & 18.5 & 39.5 & 21.0 \\
\hline B.2. Wealth: $\$ 500 \mathrm{k}$ more & 1007 & 32.6 & 16.4 & -16.2 \\
\hline B.3. Wage: $20 \%$ more & 338 & 27.1 & 37.2 & 10.1 \\
\hline B.4. Longevity: 10 more years & 662 & 31.2 & 32.6 & 1.4 \\
\hline
\end{tabular}

Notes: Weighted statistics. Each row is restricted to 50-69-year-old workers with non-missing subjective causal effect estimates. Those who answered "Don't know" or skipped any relevant questions were dropped from the analysis. (1) is only available for employees who reported less than $100 \%$ probability that their employer would allow them to flexibly choose their hours. (4) is only available for employees who reported a less than $100 \%$ probability of ever becoming self-employed. (5) is only available for workers who commute at least an hour a day. (8) is only available for full-time employees who reported less than $100 \%$ chance that they will switch to a part-time job at their current employers. (11) is only available for a random third of the sample. (12) is only available for a random two thirds of the sample. 
Table 10. OLS regressions of the subjective causal effects on P70 of selected job characteristics

\begin{tabular}{|c|c|c|c|c|c|c|}
\hline & $\begin{array}{c}\text { A.1. } \\
\text { Flexible } \\
\text { schedule } \\
{[1]} \\
\end{array}$ & $\begin{array}{c}\text { A.2. } \\
\text { Job not } \\
\text { stressful } \\
{[2]} \\
\end{array}$ & $\begin{array}{c}\text { A.3. } \\
\text { Not } \\
\text { physical } \\
{[3]} \\
\end{array}$ & $\begin{array}{c}\text { A.4. } \\
\text { Self- } \\
\text { employ. } \\
{[4]} \\
\end{array}$ & $\begin{array}{c}\text { A.6. } \\
\text { Work } \\
\text { home } \\
{[5]} \\
\end{array}$ & $\begin{array}{c}\text { A.7. } \\
\text { Job no } \\
\text { concentr. } \\
{[6]} \\
\end{array}$ \\
\hline \multicolumn{7}{|c|}{$\begin{array}{l}\text { Job constraints that will be important ( } 1 \text { if } \\
\text { yes, } 0 \text { otherwise) }\end{array}$} \\
\hline Health problems & $\begin{array}{c}6.372 \\
{[3.300]^{*}}\end{array}$ & $\begin{array}{l}-0.751 \\
{[2.069]}\end{array}$ & $\begin{array}{l}-2.196 \\
{[2.090]}\end{array}$ & $\begin{array}{l}-3.795 \\
{[3.823]}\end{array}$ & $\begin{array}{l}0.770 \\
{[2.064]}\end{array}$ & $\begin{array}{l}-0.379 \\
{[2.079]}\end{array}$ \\
\hline Caretaking & $\begin{array}{l}-4.992 \\
{[3.340]}\end{array}$ & $\begin{array}{l}-1.825 \\
{[2.134]}\end{array}$ & $\begin{array}{l}0.452 \\
{[2.157]}\end{array}$ & $\begin{array}{c}7.540 \\
{[3.906]^{*}}\end{array}$ & $\begin{array}{l}2.433 \\
{[2.123]}\end{array}$ & $\begin{array}{l}-0.731 \\
{[2.129]}\end{array}$ \\
\hline Job demands & $\begin{array}{l}-5.623 \\
{[3.407]^{*}}\end{array}$ & $\begin{array}{c}7.766 \\
{[2.075]^{* * *}}\end{array}$ & $\begin{array}{c}7.257 \\
{[2.089]^{* * *}}\end{array}$ & $\begin{array}{c}9.208 \\
{[3.912]^{* *}}\end{array}$ & $\begin{array}{l}-2.412 \\
{[2.069]}\end{array}$ & $\begin{array}{c}7.037 \\
{[2.084]^{* * *}}\end{array}$ \\
\hline Employer willingness & $\begin{array}{l}3.093 \\
{[3.481]}\end{array}$ & $\begin{array}{l}0.891 \\
{[2.411]}\end{array}$ & $\begin{array}{l}2.850 \\
{[2.420]}\end{array}$ & $\begin{array}{l}4.538 \\
{[4.136]}\end{array}$ & $\begin{array}{l}2.059 \\
{[2.391]}\end{array}$ & $\begin{array}{l}3.496 \\
{[2.404]}\end{array}$ \\
\hline Business conditions & $\begin{array}{c}7.657 \\
{[3.568]^{* *}}\end{array}$ & $\begin{array}{l}3.319 \\
{[2.264]}\end{array}$ & $\begin{array}{l}-0.118 \\
{[2.293]}\end{array}$ & $\begin{array}{l}-5.325 \\
{[4.102]}\end{array}$ & $\begin{array}{l}-2.976 \\
{[2.266]}\end{array}$ & $\begin{array}{l}1.525 \\
{[2.263]}\end{array}$ \\
\hline \multicolumn{7}{|l|}{ Current job features (0-1 scale) } \\
\hline Current job cognitive score & $\begin{array}{l}11.575 \\
{[7.776]}\end{array}$ & $\begin{array}{l}7.475 \\
{[4.846]}\end{array}$ & $\begin{array}{l}2.032 \\
{[4.906]}\end{array}$ & $\begin{array}{l}1.904 \\
{[8.893]}\end{array}$ & $\begin{array}{l}-3.102 \\
{[4.754]}\end{array}$ & $\begin{array}{l}4.956 \\
{[4.844]}\end{array}$ \\
\hline Current job physical score & $\begin{array}{l}-8.034 \\
{[5.090]}\end{array}$ & $\begin{array}{l}-0.469 \\
{[3.091]}\end{array}$ & $\begin{array}{l}-2.166 \\
{[3.106]}\end{array}$ & $\begin{array}{l}-8.493 \\
{[5.997]}\end{array}$ & $\begin{array}{l}0.125 \\
{[3.064]}\end{array}$ & $\begin{array}{l}-1.201 \\
{[3.113]}\end{array}$ \\
\hline Current job social score & $\begin{array}{l}-14.885 \\
{[7.529]^{* *}}\end{array}$ & $\begin{array}{l}-0.893 \\
{[4.744]}\end{array}$ & $\begin{array}{l}5.141 \\
{[4.745]}\end{array}$ & $\begin{array}{l}-6.880 \\
{[8.638]}\end{array}$ & $\begin{array}{l}-0.703 \\
{[4.660]}\end{array}$ & $\begin{array}{l}2.960 \\
{[4.764]}\end{array}$ \\
\hline \multicolumn{7}{|l|}{ Availability of job characteristics } \\
\hline Employer would allow part-time & $\begin{array}{c}0.053 \\
{[0.048]}\end{array}$ & $\begin{array}{c}-0.064 \\
{[0.033]^{*}}\end{array}$ & $\begin{array}{c}-0.065 \\
{[0.033]^{* *}}\end{array}$ & $\begin{array}{l}-0.078 \\
{[0.053]}\end{array}$ & $\begin{array}{l}-0.002 \\
{[0.033]}\end{array}$ & $\begin{array}{l}-0.034 \\
{[0.033]}\end{array}$ \\
\hline Employer would allow flexible hours & $\begin{array}{c}0.204 \\
{[0.052]^{* * *}}\end{array}$ & $\begin{array}{l}0.031 \\
{[0.031]}\end{array}$ & $\begin{array}{l}-0.006 \\
{[0.031]}\end{array}$ & $\begin{array}{l}0.058 \\
{[0.052]}\end{array}$ & $\begin{array}{c}0.000 \\
{[0.031]}\end{array}$ & $\begin{array}{l}-0.009 \\
{[0.030]}\end{array}$ \\
\hline Can work from home & $\begin{array}{l}-6.146 \\
{[3.354]^{*}}\end{array}$ & $\begin{array}{c}-7.390 \\
{[2.163] * * *}\end{array}$ & $\begin{array}{c}-9.734 \\
{[2.145]^{* * *}}\end{array}$ & $\begin{array}{l}-7.168 \\
{[3.789]^{*}}\end{array}$ & $\begin{array}{c}-9.402 \\
{[2.123]^{* * *}}\end{array}$ & $\begin{array}{c}-7.684 \\
{[2.148]^{* * *}}\end{array}$ \\
\hline Commute less than 60 min a day & $\begin{array}{l}1.291 \\
{[2.902]}\end{array}$ & $\begin{array}{c}1.152 \\
{[1.860]}\end{array}$ & $\begin{array}{l}2.273 \\
{[1.878]}\end{array}$ & $\begin{array}{l}-0.262 \\
{[3.275]}\end{array}$ & $\begin{array}{l}2.345 \\
{[1.849]}\end{array}$ & $\begin{array}{c}3.316 \\
{[1.868]^{*}}\end{array}$ \\
\hline Female & $\begin{array}{c}-7.402 \\
{[3.123]^{* *}}\end{array}$ & $\begin{array}{l}2.790 \\
{[1.999]}\end{array}$ & $\begin{array}{l}1.104 \\
{[2.010]}\end{array}$ & $\begin{array}{l}0.454 \\
{[3.600]}\end{array}$ & $\begin{array}{l}1.766 \\
{[1.987]}\end{array}$ & $\begin{array}{c}3.607 \\
{[1.998]^{*}}\end{array}$ \\
\hline High school or less & ref. & ref. & ref. & ref. & ref. & ref. \\
\hline Some college & $\begin{array}{l}-6.737 \\
{[3.842]^{*}}\end{array}$ & $\begin{array}{c}9.981 \\
{[2.485] * * *}\end{array}$ & $\begin{array}{c}6.624 \\
{[2.497]^{* * *}}\end{array}$ & $\begin{array}{c}9.027 \\
{[4.378]^{* *}}\end{array}$ & $\begin{array}{l}0.111 \\
{[2.451]}\end{array}$ & $\begin{array}{c}7.726 \\
{[2.492]^{* * *}}\end{array}$ \\
\hline College or more & $\begin{array}{l}-2.914 \\
{[4.138]}\end{array}$ & $\begin{array}{c}8.540 \\
{[2.577] * * *}\end{array}$ & $\begin{array}{c}5.909 \\
{[2.608]^{* *}}\end{array}$ & $\begin{array}{c}14.149 \\
{[4.626] * * *}\end{array}$ & $\begin{array}{l}0.394 \\
{[2.561]}\end{array}$ & $\begin{array}{c}5.978 \\
{[2.584]^{* *}}\end{array}$ \\
\hline Health excellent & $\begin{array}{l}1.526 \\
{[4.857]}\end{array}$ & $\begin{array}{l}-3.409 \\
{[3.076]}\end{array}$ & $\begin{array}{l}-3.546 \\
{[3.122]}\end{array}$ & $\begin{array}{l}-6.187 \\
{[5.521]}\end{array}$ & $\begin{array}{l}-4.311 \\
{[3.081]}\end{array}$ & $\begin{array}{l}-4.851 \\
{[3.064]}\end{array}$ \\
\hline Health very good & $\begin{array}{l}1.125 \\
{[3.184]}\end{array}$ & $\begin{array}{l}-3.883 \\
{[2.060]^{*}}\end{array}$ & $\begin{array}{c}-5.326 \\
{[2.071]^{* *}}\end{array}$ & $\begin{array}{c}-9.603 \\
{[3.657]^{* * *}}\end{array}$ & $\begin{array}{l}2.789 \\
{[2.054]}\end{array}$ & $\begin{array}{c}-4.843 \\
{[2.057]^{* *}}\end{array}$ \\
\hline $\begin{array}{l}\text { Health good } \\
\text { Health fair }\end{array}$ & $\begin{array}{c}\text { ref. } \\
-1.409\end{array}$ & $\begin{array}{c}\text { ref. } \\
-8.841\end{array}$ & $\begin{array}{c}\text { ref. } \\
-4.474\end{array}$ & $\begin{array}{c}\text { ref. } \\
-8.309\end{array}$ & $\begin{array}{c}\text { ref. } \\
-1.683\end{array}$ & $\begin{array}{c}\text { ref. } \\
-12.374\end{array}$ \\
\hline
\end{tabular}




\begin{tabular}{lcccccc} 
& {$[5.857]$} & {$[3.591]^{* *}$} & {$[3.629]$} & {$[6.721]$} & {$[3.574]$} & {$[3.586]^{* * *}$} \\
Health poor & -9.501 & -14.579 & -14.810 & -10.384 & 10.334 & -12.042 \\
& {$[16.677]$} & {$[7.683]^{*}$} & {$[7.660]^{*}$} & {$[17.595]$} & {$[7.606]$} & {$[7.540]$} \\
\hline Log family income & -1.831 & -3.413 & -1.303 & -1.094 & 0.802 & -2.570 \\
& {$[2.738]$} & {$[1.517]^{* *}$} & {$[1.524]$} & {$[3.148]$} & {$[1.488]$} & {$[1.544]^{*}$} \\
\hline Full-time employee & ref. & ref. & ref. & ref. & ref. & ref. \\
Part-time employee & -0.160 & 3.905 & 3.927 & 13.578 & -7.257 & 4.975 \\
& {$[4.254]$} & {$[2.826]$} & {$[2.857]$} & {$[4.946]^{* * *}$} & {$[2.740]^{* * *}$} & {$[2.802]^{*}$} \\
Full-time self-employed & - & -3.406 & -1.600 & - & 2.144 & -2.273 \\
& - & {$[3.550]$} & {$[3.519]$} & - & {$[3.477]$} & {$[3.583]$} \\
Part-time self-employed & - & 1.592 & 1.936 & - & -0.260 & 2.168 \\
& - & {$[4.083]$} & {$[4.090]$} & - & {$[4.024]$} & {$[4.067]$} \\
\hline Number series score & -0.126 & -1.521 & -1.390 & 2.211 & 2.456 & -1.092 \\
& {$[1.617]$} & {$[1.016]$} & {$[1.022]$} & {$[1.829]$} & {$[1.020]^{* *}$} & {$[1.010]$} \\
\hline Neuroticism & 2.456 & -1.525 & -0.495 & 1.182 & 2.380 & -1.897 \\
& {$[1.509]$} & {$[0.977]$} & {$[0.967]$} & {$[1.727]$} & {$[0.963]^{* *}$} & {$[0.965]^{* *}$} \\
Extroversion & 2.632 & 0.462 & 0.312 & -3.603 & -1.714 & 2.395 \\
Agreeableness & {$[1.860]$} & {$[1.199]$} & {$[1.207]$} & {$[2.142]^{*}$} & {$[1.198]$} & {$[1.191]^{* *}$} \\
Conscientiousness & -2.958 & 0.838 & 0.314 & -0.758 & 2.463 & 0.014 \\
& {$[1.724]^{*}$} & {$[1.097]$} & {$[1.102]$} & {$[1.988]$} & {$[1.083]^{* *}$} & {$[1.106]$} \\
Openness & -1.882 & 1.965 & 1.005 & -0.575 & -1.712 & 1.251 \\
& {$[1.645]$} & {$[1.030]^{*}$} & {$[1.036]$} & {$[1.870]$} & {$[1.021]^{*}$} & {$[1.039]$} \\
\hline Constant & 2.062 & -1.739 & 0.464 & 2.593 & 2.739 & -2.476 \\
\hline Age, race, marital status controls & {$[1.687]$} & {$[1.076]$} & {$[1.091]$} & {$[1.982]$} & {$[1.070]^{* *}$} & {$[1.083]^{* *}$} \\
\hline R-squared & 35.919 & 37.549 & 20.269 & 22.348 & 4.874 & 24.856 \\
N & {$[30.594]$} & {$[17.264]^{* *}$} & {$[17.357]$} & {$[35.287]$} & {$[16.962]$} & {$[17.460]$} \\
\hline
\end{tabular}

Notes: Weighted statistics. See Table 9 for definitions and sample restrictions. A handful of missing job constraints were replaced by zero (i.e. not important). Missing job characteristics, typically due to unavailability in certain labor market states, were replaced by their respective medians. 


\section{Appendix A: Full output of the regression models}

Table A1. OLS regressions of the subjective probability of working past age $\mathbf{7 0}$

\begin{tabular}{|c|c|c|c|c|c|}
\hline & {$[1]$} & [2] & {$[3]$} & [4] & {$[5]$} \\
\hline \multicolumn{6}{|l|}{ Job constraints that will be important } \\
\hline Health problems & & $\begin{array}{l}-2.086 \\
{[2.071]}\end{array}$ & & & $\begin{array}{l}-1.688 \\
{[2.066]}\end{array}$ \\
\hline Caretaking & & $\begin{array}{l}3.338 \\
{[2.158]}\end{array}$ & & & $\begin{array}{c}3.592 \\
{[2.140]^{*}}\end{array}$ \\
\hline Job demands & & $\begin{array}{c}-8.976 \\
{[2.035]^{* * *}}\end{array}$ & & & $\begin{array}{c}-9.523 \\
{[2.074]^{* * *}}\end{array}$ \\
\hline Employer willingness & & $\begin{array}{l}-0.064 \\
{[2.364]}\end{array}$ & & & $\begin{array}{l}1.216 \\
{[2.377]}\end{array}$ \\
\hline Business conditions & & $\begin{array}{c}4.603 \\
{[2.275]^{* *}} \\
\end{array}$ & & & $\begin{array}{c}5.933 \\
{[2.282]^{* * *}}\end{array}$ \\
\hline \multicolumn{6}{|l|}{ Current and future job features } \\
\hline Future job cognitive score & & & $\begin{array}{c}24.119 \\
{[5.091]^{* * *}}\end{array}$ & & $\begin{array}{c}22.159 \\
{[5.094]^{* * *}}\end{array}$ \\
\hline Current job cognitive score & & & $\begin{array}{l}-5.868 \\
{[4.937]}\end{array}$ & & $\begin{array}{l}-1.893 \\
{[4.938]}\end{array}$ \\
\hline Future job physical score & & & $\begin{array}{l}-6.212 \\
{[4.431]}\end{array}$ & & $\begin{array}{l}-8.426 \\
{[4.380]^{*}}\end{array}$ \\
\hline Current job physical score & & & $\begin{array}{l}4.367 \\
{[3.260]}\end{array}$ & & $\begin{array}{c}7.954 \\
{[3.355]^{* *}}\end{array}$ \\
\hline Future job social score & & & $\begin{array}{l}7.186 \\
{[5.336]}\end{array}$ & & $\begin{array}{l}7.253 \\
{[5.258]}\end{array}$ \\
\hline Current job social score & & & $\begin{array}{l}4.819 \\
{[5.077]}\end{array}$ & & $\begin{array}{l}1.936 \\
{[5.041]}\end{array}$ \\
\hline \multicolumn{6}{|l|}{ Availability of job characteristics } \\
\hline Employer would allow part-time & & & & $\begin{array}{l}0.049 \\
{[0.033]}\end{array}$ & $\begin{array}{c}0.06 \\
{[0.033]^{*}}\end{array}$ \\
\hline Employer would allow flexible hours & & & & $\begin{array}{c}0.084 \\
{[0.031]^{* * *}}\end{array}$ & $\begin{array}{c}0.077 \\
{[0.031]^{* *}}\end{array}$ \\
\hline Can work from home & & & & $\begin{array}{l}2.281 \\
{[2.067]}\end{array}$ & $\begin{array}{l}-0.647 \\
{[2.133]}\end{array}$ \\
\hline Commute less than 60 min a day & & & & $\begin{array}{c}5.123 \\
{[1.862]^{* * *}}\end{array}$ & $\begin{array}{c}5.323 \\
{[1.847]^{* * *}}\end{array}$ \\
\hline Female & $\begin{array}{c}-5.181 \\
{[1.977]^{* * *}}\end{array}$ & $\begin{array}{c}-5.391 \\
{[1.974]^{* * *}}\end{array}$ & $\begin{array}{l}-3.929 \\
{[2.037]^{*}}\end{array}$ & $\begin{array}{c}-5.584 \\
{[1.971]^{* * *}}\end{array}$ & $\begin{array}{c}-4.048 \\
{[2.032]^{* *}}\end{array}$ \\
\hline Black & $\begin{array}{l}-1.427 \\
{[3.230]}\end{array}$ & $\begin{array}{l}-0.58 \\
{[3.202]}\end{array}$ & $\begin{array}{l}-0.952 \\
{[3.259]}\end{array}$ & $\begin{array}{l}-1.789 \\
{[3.217]}\end{array}$ & $\begin{array}{l}0.144 \\
{[3.231]}\end{array}$ \\
\hline Other race & $\begin{array}{c}-9.489 \\
{[3.783]^{* *}}\end{array}$ & $\begin{array}{c}-11.534 \\
{[3.787]^{* * *}}\end{array}$ & $\begin{array}{c}-7.513 \\
{[3.768]^{* *}}\end{array}$ & $\begin{array}{c}-8.302 \\
{[3.771]^{* *}}\end{array}$ & $\begin{array}{c}-8.874 \\
{[3.759]^{* *}}\end{array}$ \\
\hline Hispanic & -7.373 & -7.616 & -6.787 & -6.582 & -6.53 \\
\hline
\end{tabular}




\begin{tabular}{|c|c|c|c|c|c|}
\hline & {$[2.710] * * *$} & {$[2.711]^{* * *}$} & {$[2.725]^{* *}$} & {$[2.693]^{* *}$} & {$[2.707]^{* *}$} \\
\hline Age $50-54$ & ref. & ref. & ref. & ref. & ref. \\
\hline Age $55-59$ & $\begin{array}{l}-0.726 \\
{[1.989]}\end{array}$ & $\begin{array}{l}-0.971 \\
{[1.992]}\end{array}$ & $\begin{array}{l}-0.701 \\
{[1.972]}\end{array}$ & $\begin{array}{l}-1.128 \\
{[1.981]}\end{array}$ & $\begin{array}{l}-1.523 \\
{[1.979]}\end{array}$ \\
\hline Age $60-64$ & $\begin{array}{l}-0.758 \\
{[3.070]}\end{array}$ & $\begin{array}{l}-0.935 \\
{[3.044]}\end{array}$ & $\begin{array}{l}-0.563 \\
{[3.045]}\end{array}$ & $\begin{array}{l}-1.761 \\
{[3.057]}\end{array}$ & $\begin{array}{r}-1.651 \\
{[3.008]}\end{array}$ \\
\hline Age $65-69$ & $\begin{array}{c}25.965 \\
{[4.131]^{* * *}}\end{array}$ & $\begin{array}{c}24.795 \\
{[4.117]^{* * *}}\end{array}$ & $\begin{array}{c}26.923 \\
{[4.116]^{* * *}}\end{array}$ & $\begin{array}{c}25.171 \\
{[4.103]^{* * *}}\end{array}$ & $\begin{array}{c}24.821 \\
{[4.086]^{* * *}}\end{array}$ \\
\hline High school or less & ref. & ref. & ref. & ref. & ref. \\
\hline Some college & $\begin{array}{c}2.2 \\
{[2.451]}\end{array}$ & $\begin{array}{l}1.874 \\
{[2.427]}\end{array}$ & $\begin{array}{l}0.818 \\
{[2.482]}\end{array}$ & $\begin{array}{l}1.565 \\
{[2.437]}\end{array}$ & $\begin{array}{l}0.421 \\
{[2.439]}\end{array}$ \\
\hline College or more & $\begin{array}{c}4.269 \\
{[2.476]^{*}}\end{array}$ & $\begin{array}{l}3.411 \\
{[2.460]}\end{array}$ & $\begin{array}{l}1.847 \\
{[2.653]}\end{array}$ & $\begin{array}{l}3.478 \\
{[2.474]} \\
\end{array}$ & $\begin{array}{l}0.997 \\
{[2.615]}\end{array}$ \\
\hline Married & ref. & ref. & ref. & ref. & ref. \\
\hline Divorced/separated & $\begin{array}{c}4.783 \\
{[2.505]^{*}}\end{array}$ & $\begin{array}{c}5.03 \\
{[2.491]^{* *}}\end{array}$ & $\begin{array}{c}4.508 \\
{[2.491]^{*}}\end{array}$ & $\begin{array}{c}4.935 \\
{[2.491]^{* *}}\end{array}$ & $\begin{array}{c}5.348 \\
{[2.465]^{* *}}\end{array}$ \\
\hline Widowed & $\begin{array}{c}16.649 \\
{[6.285]^{* * *}}\end{array}$ & $\begin{array}{c}18.411 \\
{[6.240]^{* * *}}\end{array}$ & $\begin{array}{c}16.534 \\
{[6.273]^{* * *}}\end{array}$ & $\begin{array}{c}14.733 \\
{[6.254]^{* *}}\end{array}$ & $\begin{array}{c}15.744 \\
{[6.191]^{* *}}\end{array}$ \\
\hline Never married & $\begin{array}{l}-4.312 \\
{[3.492]}\end{array}$ & $\begin{array}{l}-5.071 \\
{[3.488]}\end{array}$ & $\begin{array}{l}-4.61 \\
{[3.477]}\end{array}$ & $\begin{array}{l}-3.983 \\
{[3.458]}\end{array}$ & $\begin{array}{l}-4.835 \\
{[3.443]}\end{array}$ \\
\hline Health excellent & $\begin{array}{l}0.236 \\
{[3.160]}\end{array}$ & $\begin{array}{l}0.399 \\
{[3.127]}\end{array}$ & $\begin{array}{l}0.478 \\
{[3.140]}\end{array}$ & $\begin{array}{l}-0.448 \\
{[3.135]}\end{array}$ & $\begin{array}{l}0.073 \\
{[3.086]}\end{array}$ \\
\hline Health very good & $\begin{array}{l}3.007 \\
{[2.076]}\end{array}$ & $\begin{array}{c}2.99 \\
{[2.058]}\end{array}$ & $\begin{array}{c}3.4 \\
{[2.068]}\end{array}$ & $\begin{array}{l}2.999 \\
{[2.063]}\end{array}$ & $\begin{array}{c}3.707 \\
{[2.040]^{*}}\end{array}$ \\
\hline Health good & ref. & ref. & ref. & ref. & ref. \\
\hline Health fair & $\begin{array}{l}-0.153 \\
{[3.611]}\end{array}$ & $\begin{array}{l}-0.516 \\
{[3.599]}\end{array}$ & $\begin{array}{l}0.379 \\
{[3.593]}\end{array}$ & $\begin{array}{l}0.021 \\
{[3.618]}\end{array}$ & $\begin{array}{l}0.101 \\
{[3.580]}\end{array}$ \\
\hline Health poor & $\begin{array}{l}1.238 \\
{[7.893]}\end{array}$ & $\begin{array}{l}3.223 \\
{[7.886]}\end{array}$ & $\begin{array}{l}2.215 \\
{[7.850]}\end{array}$ & $\begin{array}{l}-1.035 \\
{[7.828]} \\
\end{array}$ & $\begin{array}{l}2.346 \\
{[7.795]}\end{array}$ \\
\hline Log family income & $\begin{array}{c}-7.554 \\
{[1.453]^{* * *}}\end{array}$ & $\begin{array}{c}-7.567 \\
{[1.448]^{* * *}}\end{array}$ & $\begin{array}{c}-7.328 \\
{[1.504]^{* * *}}\end{array}$ & $\begin{array}{c}-8.072 \\
{[1.471]^{* * *}}\end{array}$ & $\begin{array}{c}-7.086 \\
{[1.511]^{* * *}}\end{array}$ \\
\hline Full-time employee & ref. & ref. & ref. & ref. & ref. \\
\hline Part-time employee & $\begin{array}{c}-10.275 \\
{[2.728]^{* * *}}\end{array}$ & $\begin{array}{c}-9.747 \\
{[2.708]^{* * *}}\end{array}$ & $\begin{array}{c}-9.971 \\
{[2.768]^{* * *}}\end{array}$ & $\begin{array}{c}-12.089 \\
{[2.752]^{* * *}}\end{array}$ & $\begin{array}{c}-10.772 \\
{[2.760]^{* * *}}\end{array}$ \\
\hline Full-time self-employed & $\begin{array}{c}9.331 \\
{[3.423]^{* * *}}\end{array}$ & $\begin{array}{c}8.946 \\
{[3.430] * * *}\end{array}$ & $\begin{array}{c}9.847 \\
{[3.439]^{* * * *}}\end{array}$ & $\begin{array}{c}6.936 \\
{[3.502]^{* *}}\end{array}$ & $\begin{array}{c}8.466 \\
{[3.551]^{* *}}\end{array}$ \\
\hline Part-time self-employed & $\begin{array}{l}-2.179 \\
{[3.966]} \\
\end{array}$ & $\begin{array}{l}-2.335 \\
{[3.936]} \\
\end{array}$ & $\begin{array}{l}-2.361 \\
{[3.959]} \\
\end{array}$ & $\begin{array}{l}-4.102 \\
{[4.059]} \\
\end{array}$ & $\begin{array}{l}-2.51 \\
{[4.042]} \\
\end{array}$ \\
\hline Number series score & $\begin{array}{c}1.757 \\
{[1.029]^{*}}\end{array}$ & $\begin{array}{c}2.197 \\
{[1.021]^{* *}}\end{array}$ & $\begin{array}{c}1.41 \\
{[1.026]}\end{array}$ & $\begin{array}{c}1.724 \\
{[1.023]^{*}} \\
\end{array}$ & $\begin{array}{c}1.811 \\
{[1.015]^{*}}\end{array}$ \\
\hline Neuroticism & $\begin{array}{l}-0.286 \\
{[0.969]}\end{array}$ & $\begin{array}{l}-0.23 \\
{[0.966]}\end{array}$ & $\begin{array}{l}-0.118 \\
{[0.976]}\end{array}$ & $\begin{array}{l}-0.085 \\
{[0.963]}\end{array}$ & $\begin{array}{l}-0.046 \\
{[0.969]}\end{array}$ \\
\hline Extroversion & $\begin{array}{l}-1.052 \\
{[1.202]}\end{array}$ & $\begin{array}{l}-0.937 \\
{[1.190]}\end{array}$ & $\begin{array}{l}-1.527 \\
{[1.223]}\end{array}$ & $\begin{array}{l}-1.358 \\
{[1.199]}\end{array}$ & $\begin{array}{l}-1.989 \\
{[1.204]^{*}}\end{array}$ \\
\hline Agreeableness & $\begin{array}{c}1.919 \\
{[1.103]^{*}}\end{array}$ & $\begin{array}{l}1.507 \\
{[1.099]}\end{array}$ & $\begin{array}{c}1.67 \\
{[1.115]}\end{array}$ & $\begin{array}{c}1.959 \\
{[1.092]^{*}}\end{array}$ & $\begin{array}{l}1.299 \\
{[1.101]}\end{array}$ \\
\hline Conscientiousness & -2.335 & -2.273 & -2.278 & -2.229 & -2.058 \\
\hline
\end{tabular}




\begin{tabular}{lccccc} 
& {$[1.037]^{* *}$} & {$[1.028]^{* *}$} & {$[1.035]^{* *}$} & {$[1.027]^{* *}$} & {$[1.020]^{* *}$} \\
Openness & 3.371 & 3.356 & 2.305 & 3.157 & 2.216 \\
& {$[1.081]^{* * *}$} & {$[1.078]^{* * *}$} & {$[1.111]^{* *}$} & {$[1.082]^{* * *}$} & {$[1.100]^{* *}$} \\
\hline Constant & 117.631 & 121.046 & 97.185 & 115.336 & 87.948 \\
& {$[16.280]^{* *}$} & {$[16.396]^{* *}$} & {$[17.515]^{* *}$} & {$[16.547]^{* *}$} & {$[17.821]^{* *}$} \\
& $*$ & $*$ & $*$ & $*$ & $*$ \\
\hline R-squared & 0.131 & 0.155 & 0.155 & 0.152 & 0.197 \\
\hline
\end{tabular}

Table A2. OLS regressions of the subjective causal effects of selected job characteristics on the probability of working past age 70

\begin{tabular}{|c|c|c|c|c|c|c|}
\hline & $\begin{array}{c}\text { A.1. } \\
\text { Flexible } \\
\text { schedule } \\
{[1]} \\
\end{array}$ & $\begin{array}{c}\text { A.2. } \\
\text { Job not } \\
\text { stressful } \\
{[2]} \\
\end{array}$ & $\begin{array}{c}\text { A.3. } \\
\text { Not } \\
\text { physical } \\
{[3]} \\
\end{array}$ & $\begin{array}{c}\text { A.4. } \\
\text { Self- } \\
\text { employ. } \\
{[4]} \\
\end{array}$ & $\begin{array}{c}\text { A.6. } \\
\text { Work } \\
\text { home } \\
{[5]} \\
\end{array}$ & $\begin{array}{c}\text { A.7. } \\
\text { Job no } \\
\text { concentr. } \\
{[6]} \\
\end{array}$ \\
\hline \multicolumn{7}{|l|}{$\begin{array}{l}\text { Job constraints that will be important } \\
\text { (1 if yes, } 0 \text { otherwise })\end{array}$} \\
\hline Health problems & $\begin{array}{c}6.372 \\
{[3.300]^{*}}\end{array}$ & $\begin{array}{l}-0.751 \\
{[2.069]}\end{array}$ & $\begin{array}{l}-2.196 \\
{[2.090]}\end{array}$ & $\begin{array}{l}-3.795 \\
{[3.823]}\end{array}$ & $\begin{array}{l}0.770 \\
{[2.064]}\end{array}$ & $\begin{array}{l}-0.379 \\
{[2.079]}\end{array}$ \\
\hline Caretaking & $\begin{array}{l}-4.992 \\
{[3.340]}\end{array}$ & $\begin{array}{l}-1.825 \\
{[2.134]}\end{array}$ & $\begin{array}{l}0.452 \\
{[2.157]}\end{array}$ & $\begin{array}{c}7.540 \\
{[3.906]^{*}}\end{array}$ & $\begin{array}{l}2.433 \\
{[2.123]}\end{array}$ & $\begin{array}{l}-0.731 \\
{[2.129]}\end{array}$ \\
\hline Job demands & $\begin{array}{l}-5.623 \\
{[3.407]^{*}}\end{array}$ & $\begin{array}{c}7.766 \\
{[2.075]^{* * *}}\end{array}$ & $\begin{array}{c}7.257 \\
{[2.089]^{* * *}}\end{array}$ & $\begin{array}{c}9.208 \\
{[3.912]^{* *}}\end{array}$ & $\begin{array}{l}-2.412 \\
{[2.069]}\end{array}$ & $\begin{array}{c}7.037 \\
{[2.084]^{* * * *}}\end{array}$ \\
\hline Employer willingness & $\begin{array}{l}3.093 \\
{[3.481]}\end{array}$ & $\begin{array}{l}0.891 \\
{[2.411]}\end{array}$ & $\begin{array}{l}2.850 \\
{[2.420]}\end{array}$ & $\begin{array}{l}4.538 \\
{[4.136]}\end{array}$ & $\begin{array}{l}2.059 \\
{[2.391]}\end{array}$ & $\begin{array}{l}3.496 \\
{[2.404]}\end{array}$ \\
\hline Business conditions & $\begin{array}{c}7.657 \\
{[3.568]^{* *}}\end{array}$ & $\begin{array}{l}3.319 \\
{[2.264]}\end{array}$ & $\begin{array}{l}-0.118 \\
{[2.293]} \\
\end{array}$ & $\begin{array}{l}-5.325 \\
{[4.102]} \\
\end{array}$ & $\begin{array}{l}-2.976 \\
{[2.266]} \\
\end{array}$ & $\begin{array}{l}1.525 \\
{[2.263]}\end{array}$ \\
\hline \multicolumn{7}{|l|}{ Current job features (0-1 scale) } \\
\hline Current job cognitive score & $\begin{array}{l}11.575 \\
{[7.776]}\end{array}$ & $\begin{array}{c}7.475 \\
{[4.846]}\end{array}$ & $\begin{array}{l}2.032 \\
{[4.906]}\end{array}$ & $\begin{array}{l}1.904 \\
{[8.893]}\end{array}$ & $\begin{array}{l}-3.102 \\
{[4.754]}\end{array}$ & $\begin{array}{l}4.956 \\
{[4.844]}\end{array}$ \\
\hline Current job physical score & $\begin{array}{l}-8.034 \\
{[5.090]}\end{array}$ & $\begin{array}{l}-0.469 \\
{[3.091]}\end{array}$ & $\begin{array}{l}-2.166 \\
{[3.106]}\end{array}$ & $\begin{array}{l}-8.493 \\
{[5.997]}\end{array}$ & $\begin{array}{l}0.125 \\
{[3.064]}\end{array}$ & $\begin{array}{l}-1.201 \\
{[3.113]}\end{array}$ \\
\hline Current job social score & $\begin{array}{l}-14.885 \\
{[7.529]^{* *}}\end{array}$ & $\begin{array}{l}-0.893 \\
{[4.744]} \\
\end{array}$ & $\begin{array}{l}5.141 \\
{[4.745]}\end{array}$ & $\begin{array}{l}-6.880 \\
{[8.638]} \\
\end{array}$ & $\begin{array}{l}-0.703 \\
{[4.660]} \\
\end{array}$ & $\begin{array}{l}2.960 \\
{[4.764]}\end{array}$ \\
\hline \multicolumn{7}{|l|}{ Availability of job characteristics } \\
\hline Employer would allow part-time & $\begin{array}{l}0.053 \\
{[0.048]}\end{array}$ & $\begin{array}{l}-0.064 \\
{[0.033]^{*}}\end{array}$ & $\begin{array}{c}-0.065 \\
{[0.033]^{* *}}\end{array}$ & $\begin{array}{l}-0.078 \\
{[0.053]}\end{array}$ & $\begin{array}{l}-0.002 \\
{[0.033]}\end{array}$ & $\begin{array}{l}-0.034 \\
{[0.033]}\end{array}$ \\
\hline Employer would allow flexible hours & $\begin{array}{c}0.204 \\
{[0.052]^{* * *}}\end{array}$ & $\begin{array}{l}0.031 \\
{[0.031]}\end{array}$ & $\begin{array}{l}-0.006 \\
{[0.031]}\end{array}$ & $\begin{array}{l}0.058 \\
{[0.052]}\end{array}$ & $\begin{array}{l}0.000 \\
{[0.031]}\end{array}$ & $\begin{array}{l}-0.009 \\
{[0.030]}\end{array}$ \\
\hline Can work from home & $\begin{array}{l}-6.146 \\
{[3.354]^{*}}\end{array}$ & $\begin{array}{c}-7.390 \\
{[2.163]^{* * *}}\end{array}$ & $\begin{array}{c}-9.734 \\
{[2.145]^{* * *}}\end{array}$ & $\begin{array}{l}-7.168 \\
{[3.789]^{*}}\end{array}$ & $\begin{array}{c}-9.402 \\
{[2.123]^{* * *}}\end{array}$ & $\begin{array}{c}-7.684 \\
{[2.148]^{* * *}}\end{array}$ \\
\hline Commute less than 60 min a day & $\begin{array}{l}1.291 \\
{[2.902]}\end{array}$ & $\begin{array}{l}1.152 \\
{[1.860]}\end{array}$ & $\begin{array}{l}2.273 \\
{[1.878]}\end{array}$ & $\begin{array}{l}-0.262 \\
{[3.275]}\end{array}$ & $\begin{array}{l}2.345 \\
{[1.849]}\end{array}$ & $\begin{array}{c}3.316 \\
{[1.868]^{*}}\end{array}$ \\
\hline Female & $\begin{array}{c}-7.402 \\
{[3.123]^{* *}}\end{array}$ & $\begin{array}{l}2.790 \\
{[1.999]}\end{array}$ & $\begin{array}{l}1.104 \\
{[2.010]}\end{array}$ & $\begin{array}{c}0.454 \\
{[3.600]}\end{array}$ & $\begin{array}{l}1.766 \\
{[1.987]}\end{array}$ & $\begin{array}{c}3.607 \\
{[1.998]^{*}}\end{array}$ \\
\hline
\end{tabular}




\begin{tabular}{|c|c|c|c|c|c|c|}
\hline Black & $\begin{array}{c}20.191 \\
{[5.203]^{* * * *}}\end{array}$ & $\begin{array}{l}-1.392 \\
{[3.230]}\end{array}$ & $\begin{array}{l}-0.717 \\
{[3.262]}\end{array}$ & $\begin{array}{l}4.640 \\
{[5.726]}\end{array}$ & $\begin{array}{l}3.444 \\
{[3.179]}\end{array}$ & $\begin{array}{l}-0.557 \\
{[3.208]}\end{array}$ \\
\hline Other race & $\begin{array}{c}11.563 \\
{[5.794]^{* *}}\end{array}$ & $\begin{array}{c}11.571 \\
{[3.792]^{* * *}}\end{array}$ & $\begin{array}{c}14.718 \\
{[4.064]^{* * *}}\end{array}$ & $\begin{array}{l}1.872 \\
{[6.269]}\end{array}$ & $\begin{array}{l}0.570 \\
{[3.810]}\end{array}$ & $\begin{array}{c}11.702 \\
{[4.012]^{* * *}}\end{array}$ \\
\hline Hispanic & $\begin{array}{l}-3.707 \\
{[4.229]} \\
\end{array}$ & $\begin{array}{c}8.985 \\
{[2.766]^{* * *}}\end{array}$ & $\begin{array}{c}9.226 \\
{[2.736]^{* * *}}\end{array}$ & $\begin{array}{l}0.650 \\
{[4.834]} \\
\end{array}$ & $\begin{array}{r}-1.366 \\
{[2.701]} \\
\end{array}$ & $\begin{array}{c}9.376 \\
{[2.755]^{* * *}}\end{array}$ \\
\hline Age $50-54$ & ref. & ref. & ref. & ref. & ref. & ref. \\
\hline Age 55-59 & $\begin{array}{l}-2.179 \\
{[3.136]}\end{array}$ & $\begin{array}{l}2.154 \\
{[2.007]}\end{array}$ & $\begin{array}{l}0.053 \\
{[2.010]}\end{array}$ & $\begin{array}{l}2.041 \\
{[3.546]}\end{array}$ & $\begin{array}{r}-1.333 \\
{[1.980]}\end{array}$ & $\begin{array}{l}1.544 \\
{[1.999]}\end{array}$ \\
\hline Age $60-64$ & $\begin{array}{l}3.650 \\
{[4.835]}\end{array}$ & $\begin{array}{c}6.726 \\
{[3.022]^{* *}}\end{array}$ & $\begin{array}{l}3.960 \\
{[3.043]}\end{array}$ & $\begin{array}{l}5.595 \\
{[5.364]}\end{array}$ & $\begin{array}{l}2.882 \\
{[2.969]}\end{array}$ & $\begin{array}{l}2.940 \\
{[3.019]}\end{array}$ \\
\hline Age $65-69$ & $\begin{array}{l}-1.731 \\
{[7.918]} \\
\end{array}$ & $\begin{array}{c}-8.879 \\
{[4.080]^{* *}}\end{array}$ & $\begin{array}{c}-9.233 \\
{[4.142]^{* *}}\end{array}$ & $\begin{array}{c}-23.970 \\
{[8.358]^{* * *}}\end{array}$ & $\begin{array}{l}-0.992 \\
{[4.072]} \\
\end{array}$ & $\begin{array}{c}-15.647 \\
{[4.051] * * *}\end{array}$ \\
\hline High school or less & ref. & ref. & ref. & ref. & ref. & ref. \\
\hline Some college & $\begin{array}{l}-6.737 \\
{[3.842]^{*}}\end{array}$ & $\begin{array}{c}9.981 \\
{[2.485]^{* * * *}}\end{array}$ & $\begin{array}{c}6.624 \\
{[2.497]^{* * * *}}\end{array}$ & $\begin{array}{c}9.027 \\
{[4.378]^{* *}}\end{array}$ & $\begin{array}{l}0.111 \\
{[2.451]}\end{array}$ & $\begin{array}{c}7.726 \\
{[2.492]^{* * *}}\end{array}$ \\
\hline College or more & $\begin{array}{l}-2.914 \\
{[4.138]}\end{array}$ & $\begin{array}{c}8.540 \\
{[2.577]^{* * *}}\end{array}$ & $\begin{array}{c}5.909 \\
{[2.608]^{* *}}\end{array}$ & $\begin{array}{c}14.149 \\
{[4.626]^{* * *}}\end{array}$ & $\begin{array}{l}0.394 \\
{[2.561]}\end{array}$ & $\begin{array}{c}5.978 \\
{[2.584] * *}\end{array}$ \\
\hline Married & ref. & ref. & ref. & ref. & ref. & ref. \\
\hline Divorced/separated & $\begin{array}{l}-2.627 \\
{[3.939]}\end{array}$ & $\begin{array}{l}-1.320 \\
{[2.528]}\end{array}$ & $\begin{array}{l}1.200 \\
{[2.560]}\end{array}$ & $\begin{array}{l}-0.733 \\
{[4.482]}\end{array}$ & $\begin{array}{l}-2.938 \\
{[2.473]}\end{array}$ & $\begin{array}{l}1.661 \\
{[2.523]}\end{array}$ \\
\hline Widowed & $\begin{array}{c}21.453 \\
{[9.265]^{* *}}\end{array}$ & $\begin{array}{l}-5.907 \\
{[6.201]}\end{array}$ & $\begin{array}{l}-5.465 \\
{[6.230]}\end{array}$ & $\begin{array}{r}-10.291 \\
{[10.842]}\end{array}$ & $\begin{array}{c}6.034 \\
{[6.043]}\end{array}$ & $\begin{array}{l}-3.325 \\
{[6.189]}\end{array}$ \\
\hline Never married & $\begin{array}{l}-9.135 \\
{[5.339]^{*}}\end{array}$ & $\begin{array}{l}-1.242 \\
{[3.368]}\end{array}$ & $\begin{array}{l}-2.541 \\
{[3.404]}\end{array}$ & $\begin{array}{l}9.182 \\
{[6.130]}\end{array}$ & $\begin{array}{c}7.363 \\
{[3.371]^{* * *}} \\
\end{array}$ & $\begin{array}{l}-0.729 \\
{[3.562]}\end{array}$ \\
\hline Health excellent & $\begin{array}{l}1.526 \\
{[4.857]}\end{array}$ & $\begin{array}{l}-3.409 \\
{[3.076]}\end{array}$ & $\begin{array}{l}-3.546 \\
{[3.122]}\end{array}$ & $\begin{array}{l}-6.187 \\
{[5.521]}\end{array}$ & $\begin{array}{l}-4.311 \\
{[3.081]}\end{array}$ & $\begin{array}{l}-4.851 \\
{[3.064]}\end{array}$ \\
\hline Health very good & $\begin{array}{l}1.125 \\
{[3.184]}\end{array}$ & $\begin{array}{l}-3.883 \\
{[2.060]^{*}}\end{array}$ & $\begin{array}{c}-5.326 \\
{[2.071]^{* *}}\end{array}$ & $\begin{array}{c}-9.603 \\
{[3.657]^{* * *}}\end{array}$ & $\begin{array}{l}2.789 \\
{[2.054]}\end{array}$ & $\begin{array}{c}-4.843 \\
{[2.057]^{* *}}\end{array}$ \\
\hline Health good & ref. & ref. & ref. & ref. & ref. & ref. \\
\hline Health fair & $\begin{array}{l}-1.409 \\
{[5.857]}\end{array}$ & $\begin{array}{c}-8.841 \\
{[3.591]^{* *}}\end{array}$ & $\begin{array}{l}-4.474 \\
{[3.629]}\end{array}$ & $\begin{array}{l}-8.309 \\
{[6.721]}\end{array}$ & $\begin{array}{r}-1.683 \\
{[3.574]}\end{array}$ & $\begin{array}{c}-12.374 \\
{[3.586] * * *}\end{array}$ \\
\hline Health poor & $\begin{array}{l}-9.501 \\
{[16.677]}\end{array}$ & $\begin{array}{c}-14.579 \\
{[7.683]^{*}}\end{array}$ & $\begin{array}{c}-14.810 \\
{[7.660]^{*}}\end{array}$ & $\begin{array}{c}-10.384 \\
{[17.595]}\end{array}$ & $\begin{array}{l}10.334 \\
{[7.606]}\end{array}$ & $\begin{array}{c}-12.042 \\
{[7.540]}\end{array}$ \\
\hline Log family income & $\begin{array}{l}-1.831 \\
{[2.738]} \\
\end{array}$ & $\begin{array}{c}-3.413 \\
{[1.517]^{* *}} \\
\end{array}$ & $\begin{array}{r}-1.303 \\
{[1.524]} \\
\end{array}$ & $\begin{array}{r}-1.094 \\
{[3.148]} \\
\end{array}$ & $\begin{array}{c}0.802 \\
{[1.488]}\end{array}$ & $\begin{array}{l}-2.570 \\
{[1.544]^{*}} \\
\end{array}$ \\
\hline Full-time employee & ref. & ref. & ref. & ref. & ref. & ref. \\
\hline Part-time employee & $\begin{array}{l}-0.160 \\
{[4.254]}\end{array}$ & $\begin{array}{l}3.905 \\
{[2.826]}\end{array}$ & $\begin{array}{l}3.927 \\
{[2.857]}\end{array}$ & $\begin{array}{c}13.578 \\
{[4.946]^{* * *}}\end{array}$ & $\begin{array}{c}-7.257 \\
{[2.740]^{* * *}}\end{array}$ & $\begin{array}{c}4.975 \\
{[2.802]^{*}}\end{array}$ \\
\hline Full-time self-employed & $\begin{array}{l}- \\
-\end{array}$ & $\begin{array}{l}-3.406 \\
{[3.550]}\end{array}$ & $\begin{array}{l}-1.600 \\
{[3.519]}\end{array}$ & $\begin{array}{l}- \\
-\end{array}$ & $\begin{array}{l}2.144 \\
{[3.477]}\end{array}$ & $\begin{array}{l}-2.273 \\
{[3.583]}\end{array}$ \\
\hline Part-time self-employed & $\begin{array}{l}- \\
-\end{array}$ & $\begin{array}{c}1.592 \\
{[4.083]}\end{array}$ & $\begin{array}{c}1.936 \\
{[4.090]}\end{array}$ & $\begin{array}{l}- \\
-\end{array}$ & $\begin{array}{l}-0.260 \\
{[4.024]}\end{array}$ & $\begin{array}{l}2.168 \\
{[4.067]}\end{array}$ \\
\hline Number series score & $\begin{array}{l}-0.126 \\
{[1.617]}\end{array}$ & $\begin{array}{l}-1.521 \\
{[1.016]}\end{array}$ & $\begin{array}{l}-1.390 \\
{[1.022]}\end{array}$ & $\begin{array}{l}2.211 \\
{[1.829]}\end{array}$ & $\begin{array}{c}2.456 \\
{[1.020]^{* *}} \\
\end{array}$ & $\begin{array}{l}-1.092 \\
{[1.010]}\end{array}$ \\
\hline Neuroticism & $\begin{array}{l}2.456 \\
{[1.509]}\end{array}$ & $\begin{array}{l}-1.525 \\
{[0.977]}\end{array}$ & $\begin{array}{l}-0.495 \\
{[0.967]}\end{array}$ & $\begin{array}{l}1.182 \\
{[1.727]}\end{array}$ & $\begin{array}{c}2.380 \\
{[0.963]^{* *}}\end{array}$ & $\begin{array}{c}-1.897 \\
{[0.965]^{* *}}\end{array}$ \\
\hline
\end{tabular}




\begin{tabular}{lcccccc} 
Extroversion & 2.632 & 0.462 & 0.312 & -3.603 & -1.714 & 2.395 \\
& {$[1.860]$} & {$[1.199]$} & {$[1.207]$} & {$[2.142]^{*}$} & {$[1.198]$} & {$[1.191]^{* *}$} \\
Agreeableness & -2.958 & 0.838 & 0.314 & -0.758 & 2.463 & 0.014 \\
& {$[1.724]^{*}$} & {$[1.097]$} & {$[1.102]$} & {$[1.988]$} & {$[1.083]^{* *}$} & {$[1.106]$} \\
Conscientiousness & -1.882 & 1.965 & 1.005 & -0.575 & -1.712 & 1.251 \\
& {$[1.645]$} & {$[1.030]^{*}$} & {$[1.036]$} & {$[1.870]$} & {$[1.021]^{*}$} & {$[1.039]$} \\
Openness & 2.062 & -1.739 & 0.464 & 2.593 & 2.739 & -2.476 \\
& {$[1.687]$} & {$[1.076]$} & {$[1.091]$} & {$[1.982]$} & {$[1.070]^{* *}$} & {$[1.083]^{* *}$} \\
\hline Constant & 35.919 & 37.549 & 20.269 & 22.348 & 4.874 & 24.856 \\
& {$[30.594]$} & {$[17.264]^{* *}$} & {$[17.357]$} & {$[35.287]$} & {$[16.962]$} & {$[17.460]$} \\
\hline R-squared & 0.129 & 0.134 & 0.125 & 0.116 & 0.080 & 0.143 \\
$\mathrm{~N}$ & 656 & 990 & 975 & 712 & 989 & 972 \\
\hline
\end{tabular}

Notes: ALP, weighted. See Table 9 for definitions and sample restrictions. 


\section{Appendix B: Additional tables}

Table B1. Reported ratings (0-10) of different work-to-retirement pathways

\begin{tabular}{|c|c|c|c|c|c|c|c|c|}
\hline & \multirow[t]{2}{*}{ All } & \multirow[t]{2}{*}{ Males } & \multirow[t]{2}{*}{ Females } & \multicolumn{2}{|c|}{ Employees } & \multicolumn{2}{|c|}{ Self-employed } & \multirow{2}{*}{$\begin{array}{c}\text { Not } \\
\text { currently } \\
\text { working }\end{array}$} \\
\hline & & & & Full-t. & Part-t. & Full-t. & Part-t. & \\
\hline Work full time, retire at age 62 & 5.60 & 5.59 & 5.60 & 5.98 & 4.80 & 4.69 & 3.84 & 5.75 \\
\hline Work full time, retire at age 65 & 5.32 & 5.15 & 5.49 & 5.74 & 4.32 & 4.63 & 3.78 & 5.42 \\
\hline Work full time, retire at age 70 & 4.08 & 3.94 & 4.22 & 4.18 & 3.70 & 4.76 & 3.74 & 3.96 \\
\hline Start part time at 62 , retire at 65 & 4.51 & 4.18 & 4.84 & 4.78 & 4.32 & 4.97 & 4.31 & 4.01 \\
\hline Start part time at 62 , retire at 70 & 4.02 & 3.72 & 4.33 & 3.97 & 4.37 & 4.25 & 3.95 & 3.91 \\
\hline Start part time at 65 , retire at 70 & 3.98 & 3.67 & 4.30 & 4.11 & 4.12 & 4.05 & 4.11 & 3.64 \\
\hline Start self-emp. at 62 , retire at 70 & 3.74 & 3.72 & 3.76 & 3.65 & 3.13 & 5.61 & 5.00 & 3.57 \\
\hline Never retire & 2.80 & 2.78 & 2.83 & 2.46 & 3.55 & 4.64 & 3.30 & 2.59 \\
\hline Stop work at 62, start 65, stop 70 & 3.02 & 2.82 & 3.22 & 3.11 & 3.28 & 2.15 & 2.93 & 2.94 \\
\hline
\end{tabular}

Note: ALP, age 50-80, $\mathrm{N}=2,013$. Weighted averages.

Table B2. OLS regressions of the preferred work-to-retirement pathways

\begin{tabular}{lccccc}
\hline & $\begin{array}{c}\text { Full-time } \\
\text { to retire } \\
{[1]}\end{array}$ & $\begin{array}{c}\text { Some } \\
\text { part-time } \\
{[2]}\end{array}$ & $\begin{array}{c}\text { Some self- } \\
\text { emp. } \\
{[3]}\end{array}$ & $\begin{array}{c}\text { Never } \\
\text { retire } \\
{[4]}\end{array}$ & $\begin{array}{c}\text { Unretire } \\
{[5]}\end{array}$ \\
\hline \hline Female & -0.053 & 0.105 & -0.013 & -0.054 & 0.014 \\
& {$[0.024]^{* *}$} & {$[0.021]^{* * *}$} & {$[0.013]$} & {$[0.015]^{* * *}$} & {$[0.010]$} \\
\hline Black & -0.027 & -0.007 & 0.012 & -0.066 & 0.088 \\
& {$[0.040]$} & {$[0.034]$} & {$[0.021]$} & {$[0.025]^{* * *}$} & {$[0.016]^{* * *}$} \\
Other race & -0.010 & 0.040 & 0.036 & -0.065 & -0.001 \\
& {$[0.050]$} & {$[0.043]$} & {$[0.026]$} & {$[0.031]^{* *}$} & {$[0.020]$} \\
Hispanic & -0.053 & 0.047 & 0.009 & -0.017 & 0.014 \\
& {$[0.032]^{*}$} & {$[0.028]^{*}$} & {$[0.017]$} & {$[0.020]$} & {$[0.013]$} \\
\hline Age 50-54 & ref. & ref. & ref. & ref. & ref. \\
Age 55-59 & 0.078 & -0.055 & -0.037 & 0.050 & -0.036 \\
& {$[0.027]^{* * *}$} & {$[0.023]^{* *}$} & {$[0.014]^{* * *}$} & {$[0.017]^{* * *}$} & {$[0.011]^{* * *}$} \\
Age 60-64 & 0.029 & -0.023 & -0.038 & 0.044 & -0.012 \\
& {$[0.038]$} & {$[0.032]$} & {$[0.020]^{*}$} & {$[0.024]^{* *}$} & {$[0.015]$} \\
Age 65-69 & 0.022 & -0.046 & -0.073 & 0.078 & 0.018 \\
& {$[0.044]$} & {$[0.038]$} & {$[0.023]^{* * *}$} & {$[0.028]^{* * *}$} & {$[0.018]$} \\
Age 70-74 & 0.039 & -0.110 & -0.086 & 0.143 & 0.014 \\
& {$[0.051]$} & {$[0.044]^{* *}$} & {$[0.027]^{* * *}$} & {$[0.032]^{* * *}$} & {$[0.020]$}
\end{tabular}




\begin{tabular}{|c|c|c|c|c|c|}
\hline Age $75-80$ & $\begin{array}{l}0.023 \\
{[0.066]}\end{array}$ & $\begin{array}{l}-0.083 \\
{[0.057]}\end{array}$ & $\begin{array}{c}-0.070 \\
{[0.035]^{* *}}\end{array}$ & $\begin{array}{c}0.119 \\
{[0.042]^{* * *}}\end{array}$ & $\begin{array}{l}0.010 \\
{[0.026]}\end{array}$ \\
\hline High school or less & ref. & ref. & ref. & ref. & ref. \\
\hline Some college & $\begin{array}{l}-0.037 \\
{[0.029]}\end{array}$ & $\begin{array}{c}-0.091 \\
{[0.025]^{* * *}}\end{array}$ & $\begin{array}{c}0.047 \\
{[0.016]^{* * *}}\end{array}$ & $\begin{array}{c}0.073 \\
{[0.019]^{* * *}}\end{array}$ & $\begin{array}{l}0.008 \\
{[0.012]}\end{array}$ \\
\hline College or more & $\begin{array}{l}-0.058 \\
{[0.032]^{*}}\end{array}$ & $\begin{array}{c}-0.080 \\
{[0.027]^{* * *}}\end{array}$ & $\begin{array}{c}0.041 \\
{[0.017]^{* *}}\end{array}$ & $\begin{array}{c}0.111 \\
{[0.020] * * *}\end{array}$ & $\begin{array}{l}-0.013 \\
{[0.013]}\end{array}$ \\
\hline Married & ref. & ref. & ref. & ref. & ref. \\
\hline Divorced/separated & $\begin{array}{l}-0.009 \\
{[0.031]}\end{array}$ & $\begin{array}{l}0.035 \\
{[0.026]}\end{array}$ & $\begin{array}{l}-0.008 \\
{[0.016]}\end{array}$ & $\begin{array}{l}0.011 \\
{[0.019]}\end{array}$ & $\begin{array}{c}-0.029 \\
{[0.012]^{* *}}\end{array}$ \\
\hline Widowed & $\begin{array}{l}-0.096 \\
{[0.055]^{*}}\end{array}$ & $\begin{array}{c}0.091 \\
{[0.047]^{*}}\end{array}$ & $\begin{array}{l}-0.013 \\
{[0.029]}\end{array}$ & $\begin{array}{l}0.015 \\
{[0.034]}\end{array}$ & $\begin{array}{l}0.003 \\
{[0.022]}\end{array}$ \\
\hline Never married & $\begin{array}{l}0.010 \\
{[0.042]}\end{array}$ & $\begin{array}{l}0.006 \\
{[0.036]}\end{array}$ & $\begin{array}{l}0.013 \\
{[0.022]}\end{array}$ & $\begin{array}{l}-0.029 \\
{[0.026]} \\
\end{array}$ & $\begin{array}{l}-0.001 \\
{[0.017]} \\
\end{array}$ \\
\hline Health excellent & $\begin{array}{l}0.003 \\
{[0.040]}\end{array}$ & $\begin{array}{l}-0.042 \\
{[0.035]}\end{array}$ & $\begin{array}{l}-0.038 \\
{[0.022]^{*}}\end{array}$ & $\begin{array}{l}0.035 \\
{[0.025]}\end{array}$ & $\begin{array}{c}0.042 \\
{[0.016]^{* * * *}}\end{array}$ \\
\hline Health very good & $\begin{array}{l}0.035 \\
{[0.026]}\end{array}$ & $\begin{array}{l}-0.033 \\
{[0.022]}\end{array}$ & $\begin{array}{l}-0.008 \\
{[0.014]}\end{array}$ & $\begin{array}{l}-0.028 \\
{[0.016]^{*}}\end{array}$ & $\begin{array}{c}0.034 \\
{[0.010]^{* * * *}}\end{array}$ \\
\hline Health good & ref. & ref. & ref. & ref. & ref. \\
\hline Health fair & $\begin{array}{c}0.074 \\
{[0.038]^{*}}\end{array}$ & $\begin{array}{c}-0.088 \\
{[0.033]^{* * * *}}\end{array}$ & $\begin{array}{l}-0.033 \\
{[0.020]}\end{array}$ & $\begin{array}{c}0.049 \\
{[0.024]^{* *}}\end{array}$ & $\begin{array}{l}-0.002 \\
{[0.015]}\end{array}$ \\
\hline Health poor & $\begin{array}{l}-0.062 \\
{[0.066]}\end{array}$ & $\begin{array}{l}-0.028 \\
{[0.057]}\end{array}$ & $\begin{array}{c}-0.080 \\
{[0.035]^{* *}}\end{array}$ & $\begin{array}{l}0.068 \\
{[0.042]}\end{array}$ & $\begin{array}{c}0.102 \\
{[0.026]^{* * * *}}\end{array}$ \\
\hline Log family income & $\begin{array}{c}0.034 \\
{[0.017]^{* *}}\end{array}$ & $\begin{array}{l}0.008 \\
{[0.014]}\end{array}$ & $\begin{array}{l}0.006 \\
{[0.009]}\end{array}$ & $\begin{array}{c}-0.040 \\
{[0.011]^{* * *}}\end{array}$ & $\begin{array}{r}-0.008 \\
{[0.007]}\end{array}$ \\
\hline Full-time employee & ref. & ref. & ref. & ref. & ref. \\
\hline Part-time employee & $\begin{array}{c}-0.152 \\
{[0.037]^{* * * *}}\end{array}$ & $\begin{array}{c}0.119 \\
{[0.032]^{* * *}}\end{array}$ & $\begin{array}{c}0.045 \\
{[0.020]^{* *}}\end{array}$ & $\begin{array}{l}-0.034 \\
{[0.023]}\end{array}$ & $\begin{array}{l}0.023 \\
{[0.015]}\end{array}$ \\
\hline Full-time self-employed & $\begin{array}{c}-0.214 \\
{[0.047]^{* * *}}\end{array}$ & $\begin{array}{c}-0.069 \\
{[0.041]^{*}}\end{array}$ & $\begin{array}{c}0.187 \\
{[0.025]^{* * * *}}\end{array}$ & $\begin{array}{c}0.119 \\
{[0.030] * * *}\end{array}$ & $\begin{array}{l}-0.023 \\
{[0.019]}\end{array}$ \\
\hline Part-time self-employed & $\begin{array}{c}-0.259 \\
{[0.056]^{* * * *}}\end{array}$ & $\begin{array}{l}-0.011 \\
{[0.048]}\end{array}$ & $\begin{array}{c}0.246 \\
{[0.030]^{* * * *}}\end{array}$ & $\begin{array}{l}-0.004 \\
{[0.035]}\end{array}$ & $\begin{array}{l}0.028 \\
{[0.022]}\end{array}$ \\
\hline Not working & $\begin{array}{c}0.061 \\
{[0.033]^{*}}\end{array}$ & $\begin{array}{l}0.011 \\
{[0.029]}\end{array}$ & $\begin{array}{c}0.052 \\
{[0.018]^{* * *}}\end{array}$ & $\begin{array}{c}-0.090 \\
{[0.021] * * *}\end{array}$ & $\begin{array}{c}-0.033 \\
{[0.013]^{* *}}\end{array}$ \\
\hline Cognitive job (current or last) & $\begin{array}{c}0.102 \\
{[0.056]^{*}}\end{array}$ & $\begin{array}{l}0.013 \\
{[0.048]}\end{array}$ & $\begin{array}{l}-0.001 \\
{[0.030]}\end{array}$ & $\begin{array}{c}-0.103 \\
{[0.035]^{* * *}}\end{array}$ & $\begin{array}{l}-0.011 \\
{[0.022]}\end{array}$ \\
\hline Physical job (current or last) & $\begin{array}{l}-0.037 \\
{[0.035]}\end{array}$ & $\begin{array}{l}-0.019 \\
{[0.031]}\end{array}$ & $\begin{array}{l}0.022 \\
{[0.019]}\end{array}$ & $\begin{array}{l}0.023 \\
{[0.022]}\end{array}$ & $\begin{array}{l}0.011 \\
{[0.014]}\end{array}$ \\
\hline Social job (current or last) & $\begin{array}{l}0.072 \\
{[0.056]}\end{array}$ & $\begin{array}{l}-0.056 \\
{[0.048]}\end{array}$ & $\begin{array}{l}-0.049 \\
{[0.030]^{*}}\end{array}$ & $\begin{array}{l}0.046 \\
{[0.035]}\end{array}$ & $\begin{array}{l}-0.012 \\
{[0.022]}\end{array}$ \\
\hline Number series score & $\begin{array}{c}-0.063 \\
{[0.012]^{* * *}}\end{array}$ & $\begin{array}{c}0.062 \\
{[0.010]^{* * *}}\end{array}$ & $\begin{array}{c}0.016 \\
{[0.006]^{* *}} \\
\end{array}$ & $\begin{array}{c}-0.013 \\
{[0.008]^{*}}\end{array}$ & $\begin{array}{l}-0.003 \\
{[0.005]}\end{array}$ \\
\hline Neuroticism & $\begin{array}{l}0.003 \\
{[0.012]}\end{array}$ & $\begin{array}{c}0.020 \\
{[0.010]^{* *}}\end{array}$ & $\begin{array}{c}-0.014 \\
{[0.006]^{* *}}\end{array}$ & $\begin{array}{c}-0.018 \\
{[0.008]^{* *}}\end{array}$ & $\begin{array}{c}0.009 \\
{[0.005]^{*}}\end{array}$ \\
\hline Extroversion & $\begin{array}{l}-0.017 \\
{[0.015]}\end{array}$ & $\begin{array}{l}0.001 \\
{[0.013]}\end{array}$ & $\begin{array}{l}-0.011 \\
{[0.008]}\end{array}$ & $\begin{array}{c}0.024 \\
{[0.009]^{* * * *}}\end{array}$ & $\begin{array}{l}0.002 \\
{[0.006]}\end{array}$ \\
\hline Agreeableness & 0.007 & -0.007 & 0.012 & -0.003 & -0.009 \\
\hline
\end{tabular}




\begin{tabular}{lccccc} 
& {$[0.013]$} & {$[0.012]$} & {$[0.007]$} & {$[0.008]$} & {$[0.005]^{*}$} \\
Conscientiousness & 0.011 & 0.028 & -0.023 & -0.019 & 0.004 \\
Openness & {$[0.012]$} & {$[0.011]^{* *}$} & {$[0.007]^{* * *}$} & {$[0.008]^{* *}$} & {$[0.005]$} \\
& -0.043 & 0.013 & 0.013 & 0.008 & 0.010 \\
\hline Constant & {$[0.013]^{* * *}$} & {$[0.011]$} & {$[0.007]^{*}$} & {$[0.008]$} & {$[0.005]^{*}$} \\
\hline R-squared & 0.096 & 0.223 & 0.016 & 0.539 & 0.126 \\
\hline & {$[0.192]$} & {$[0.165]$} & {$[0.102]$} & {$[0.121]^{* * *}$} & {$[0.076]^{*}$} \\
\hline
\end{tabular}

Notes: ALP, age 50-80, $\mathrm{N}=2,013$. Weighted. ***, and *** indicate statistical significance at $10 \%, 5 \%$, and $1 \%$ respectively. The outcome variables are indicators that the person gave the highest rating for the particular pathway. Table 2 provides details of the variables. "Full-time to retire" refers to any of the "Work full time, then retire at age X" type pathways. "Some part-time" refers to any of the "Start part time at X, then retire at Y" type pathways. "Some self-emp." refers to "Start self-emp. at 62, then retire at 70." "Unretire" refers to "Stop work at 62, start at 65, stop at 70."

Table B3. Current and future job features by sector

\begin{tabular}{|c|c|c|c|c|c|c|}
\hline & \multicolumn{2}{|c|}{ Private sector } & \multicolumn{2}{|c|}{ Public sector } & \multicolumn{2}{|c|}{ Non-profit sector } \\
\hline & $\begin{array}{c}\text { current } \\
\text { job }\end{array}$ & $\begin{array}{c}\text { future } \\
\text { job }\end{array}$ & $\begin{array}{c}\text { current } \\
\text { job } \\
\end{array}$ & $\begin{array}{c}\text { future } \\
\text { job }\end{array}$ & $\begin{array}{c}\text { current } \\
\text { job }\end{array}$ & $\begin{array}{c}\text { future } \\
\text { job }\end{array}$ \\
\hline \multicolumn{7}{|l|}{ Cognitive job features } \\
\hline Monitor information & 0.771 & 0.543 & 0.738 & 0.518 & 0.827 & 0.602 \\
\hline Thinking & 0.735 & 0.569 & 0.781 & 0.542 & 0.789 & 0.673 \\
\hline Variety of skills & 0.821 & 0.674 & 0.761 & 0.625 & 0.888 & 0.719 \\
\hline High level skills & 0.601 & 0.519 & 0.612 & 0.512 & 0.696 & 0.561 \\
\hline Not simple tasks & 0.589 & 0.448 & 0.571 & 0.376 & 0.619 & 0.470 \\
\hline Solve problems & 0.554 & 0.595 & 0.519 & 0.559 & 0.613 & 0.621 \\
\hline Average cognitive & 0.678 & 0.558 & 0.664 & $\mathbf{0 . 5 2 2}$ & 0.738 & 0.608 \\
\hline \multicolumn{7}{|l|}{ Physical job features } \\
\hline Muscular strength & 0.289 & 0.129 & 0.324 & 0.164 & 0.208 & 0.149 \\
\hline Physical effort & 0.383 & 0.226 & 0.384 & 0.206 & 0.351 & 0.175 \\
\hline Average physical & 0.336 & $\mathbf{0 . 1 7 7}$ & 0.354 & 0.185 & 0.279 & 0.162 \\
\hline \multicolumn{7}{|l|}{ Social job features } \\
\hline Coworkers friendly & 0.771 & 0.867 & 0.760 & 0.851 & 0.755 & 0.896 \\
\hline Can get to know other people & 0.799 & 0.765 & 0.822 & 0.751 & 0.848 & 0.812 \\
\hline Can develop friendships & 0.573 & 0.634 & 0.616 & 0.644 & 0.659 & 0.656 \\
\hline Coworkers take personal interest & 0.602 & 0.614 & 0.564 & 0.599 & 0.648 & 0.648 \\
\hline Average social & 0.686 & $\mathbf{0 . 7 2 0}$ & 0.691 & 0.711 & 0.727 & $\mathbf{0 . 7 5 3}$ \\
\hline \multicolumn{7}{|l|}{ Other job features } \\
\hline Comfortable temperature & 0.683 & 0.788 & 0.649 & 0.757 & 0.707 & 0.694 \\
\hline Flexible schedule & 0.595 & 0.712 & 0.514 & 0.677 & 0.531 & 0.672 \\
\hline
\end{tabular}


Table B4. OLS regressions of the difference between desired future and current actual job features

\begin{tabular}{|c|c|c|c|}
\hline & $\begin{array}{c}\text { Cognitive } \\
{[1]} \\
\end{array}$ & $\begin{array}{c}\text { Physical } \\
{[2]} \\
\end{array}$ & $\begin{array}{c}\text { Social } \\
{[3]} \\
\end{array}$ \\
\hline Female & $\begin{array}{c}-0.038 \\
{[0.014]^{* * *}}\end{array}$ & $\begin{array}{l}0.025 \\
{[0.019]} \\
\end{array}$ & $\begin{array}{l}0.007 \\
{[0.013]}\end{array}$ \\
\hline Black & $\begin{array}{c}0.067 \\
{[0.023] * * *}\end{array}$ & $\begin{array}{l}0.046 \\
{[0.031]}\end{array}$ & $\begin{array}{c}-0.067 \\
{[0.021] * * *}\end{array}$ \\
\hline Other race & $\begin{array}{c}-0.077 \\
{[0.028]^{* * *}}\end{array}$ & $\begin{array}{r}-0.040 \\
{[0.038]}\end{array}$ & $\begin{array}{l}0.011 \\
{[0.026]}\end{array}$ \\
\hline Hispanic & $\begin{array}{l}-0.020 \\
{[0.019]} \\
\end{array}$ & $\begin{array}{c}-0.089 \\
{[0.026]^{* * *}}\end{array}$ & $\begin{array}{c}-0.075 \\
{[0.018]^{* * *}}\end{array}$ \\
\hline Age $50-54$ & ref. & ref. & ref. \\
\hline Age 55-59 & $\begin{array}{l}-0.006 \\
{[0.015]}\end{array}$ & $\begin{array}{l}-0.004 \\
{[0.020]}\end{array}$ & $\begin{array}{l}0.001 \\
{[0.014]}\end{array}$ \\
\hline Age $60-64$ & $\begin{array}{l}-0.004 \\
{[0.022]}\end{array}$ & $\begin{array}{l}-0.010 \\
{[0.030]}\end{array}$ & $\begin{array}{l}-0.006 \\
{[0.021]}\end{array}$ \\
\hline Age $65-69$ & $\begin{array}{c}-0.059 \\
{[0.030]^{*}}\end{array}$ & $\begin{array}{l}-0.021 \\
{[0.041]}\end{array}$ & $\begin{array}{l}-0.025 \\
{[0.028]}\end{array}$ \\
\hline Age 70-74 & $\begin{array}{l}-0.039 \\
{[0.040]}\end{array}$ & $\begin{array}{l}0.055 \\
{[0.054]}\end{array}$ & $\begin{array}{l}0.004 \\
{[0.037]}\end{array}$ \\
\hline Age $75-80$ & $\begin{array}{l}-0.065 \\
{[0.064]} \\
\end{array}$ & $\begin{array}{l}0.054 \\
{[0.087]}\end{array}$ & $\begin{array}{c}0.112 \\
{[0.060]^{*}}\end{array}$ \\
\hline High school or less & ref. & ref. & ref. \\
\hline Some college & $\begin{array}{l}0.020 \\
{[0.018]}\end{array}$ & $\begin{array}{l}0.035 \\
{[0.024]}\end{array}$ & $\begin{array}{l}0.015 \\
{[0.016]}\end{array}$ \\
\hline College or more & $\begin{array}{c}0.034 \\
{[0.018]^{*}}\end{array}$ & $\begin{array}{c}0.132 \\
{[0.024]^{* * *}}\end{array}$ & $\begin{array}{l}0.027 \\
{[0.017]}\end{array}$ \\
\hline Married & ref. & ref. & ref. \\
\hline Divorced/separated & $\begin{array}{l}0.008 \\
{[0.018]}\end{array}$ & $\begin{array}{l}0.019 \\
{[0.024]}\end{array}$ & $\begin{array}{l}-0.025 \\
{[0.017]}\end{array}$ \\
\hline Widowed & $\begin{array}{l}0.053 \\
{[0.039]}\end{array}$ & $\begin{array}{l}-0.101 \\
{[0.053]^{*}}\end{array}$ & $\begin{array}{l}0.053 \\
{[0.037]}\end{array}$ \\
\hline Never married & $\begin{array}{l}-0.011 \\
{[0.024]}\end{array}$ & $\begin{array}{c}0.070 \\
{[0.033]^{* *}}\end{array}$ & $\begin{array}{l}-0.035 \\
{[0.023]}\end{array}$ \\
\hline Health excellent & $\begin{array}{l}0.034 \\
{[0.022]}\end{array}$ & $\begin{array}{c}0.100 \\
{[0.030]^{* * *}}\end{array}$ & $\begin{array}{l}-0.002 \\
{[0.021]}\end{array}$ \\
\hline Health very good & $\begin{array}{l}0.015 \\
{[0.015]}\end{array}$ & $\begin{array}{l}0.026 \\
{[0.020]}\end{array}$ & $\begin{array}{l}-0.005 \\
{[0.014]}\end{array}$ \\
\hline Health good & ref. & ref. & ref. \\
\hline Health fair & $\begin{array}{c}-0.057 \\
{[0.025]^{* *}}\end{array}$ & $\begin{array}{l}-0.034 \\
{[0.034]}\end{array}$ & $\begin{array}{l}-0.034 \\
{[0.024]}\end{array}$ \\
\hline Health poor & $\begin{array}{l}0.066 \\
{[0.055]}\end{array}$ & $\begin{array}{l}-0.066 \\
{[0.074]} \\
\end{array}$ & $\begin{array}{l}0.082 \\
{[0.051]}\end{array}$ \\
\hline Log family income & $\begin{array}{c}-0.047 \\
{[0.010]^{* * *}}\end{array}$ & $\begin{array}{c}0.043 \\
{[0.014]^{* * *}}\end{array}$ & $\begin{array}{c}-0.053 \\
{[0.010]^{* * *}}\end{array}$ \\
\hline
\end{tabular}




\begin{tabular}{|c|c|c|c|}
\hline Full-time employee & ref. & ref. & ref. \\
\hline Part-time employee & $\begin{array}{c}0.099 \\
{[0.019]^{* * *}}\end{array}$ & $\begin{array}{l}-0.014 \\
{[0.025]}\end{array}$ & $\begin{array}{l}0.025 \\
{[0.018]}\end{array}$ \\
\hline Full-time self-employed & $\begin{array}{l}0.000 \\
{[0.024]}\end{array}$ & $\begin{array}{l}-0.028 \\
{[0.033]}\end{array}$ & $\begin{array}{l}0.022 \\
{[0.023]}\end{array}$ \\
\hline Part-time self-employed & $\begin{array}{c}0.098 \\
{[0.028]^{* * *}}\end{array}$ & $\begin{array}{l}-0.001 \\
{[0.038]}\end{array}$ & $\begin{array}{l}0.016 \\
{[0.026]}\end{array}$ \\
\hline Private Sector & ref. & ref. & ref. \\
\hline Public sector & $\begin{array}{l}-0.021 \\
{[0.017]}\end{array}$ & $\begin{array}{l}-0.006 \\
{[0.023]}\end{array}$ & $\begin{array}{l}-0.014 \\
{[0.016]}\end{array}$ \\
\hline Non-profit sector & $\begin{array}{l}-0.011 \\
{[0.027]}\end{array}$ & $\begin{array}{l}0.008 \\
{[0.036]}\end{array}$ & $\begin{array}{l}-0.013 \\
{[0.025]}\end{array}$ \\
\hline Works, sector missing & $\begin{array}{l}-0.012 \\
{[0.016]}\end{array}$ & $\begin{array}{l}-0.017 \\
{[0.022]}\end{array}$ & $\begin{array}{l}-0.026 \\
{[0.015]^{*}}\end{array}$ \\
\hline Number series score & $\begin{array}{c}0.021 \\
{[0.007]^{* * *}}\end{array}$ & $\begin{array}{l}-0.005 \\
{[0.010]}\end{array}$ & $\begin{array}{l}0.006 \\
{[0.007]}\end{array}$ \\
\hline Neuroticism & $\begin{array}{l}-0.011 \\
{[0.007]}\end{array}$ & $\begin{array}{l}-0.007 \\
{[0.009]}\end{array}$ & $\begin{array}{c}0.027 \\
{[0.007]^{* * *}}\end{array}$ \\
\hline Extroversion & $\begin{array}{c}-0.020 \\
{[0.009]^{* *}}\end{array}$ & $\begin{array}{c}-0.064 \\
{[0.012]^{* * *}}\end{array}$ & $\begin{array}{l}-0.008 \\
{[0.008]}\end{array}$ \\
\hline Agreeableness & $\begin{array}{l}-0.006 \\
{[0.008]}\end{array}$ & $\begin{array}{c}0.022 \\
{[0.011]^{* *}}\end{array}$ & $\begin{array}{c}0.026 \\
{[0.007]^{* * *}}\end{array}$ \\
\hline Conscientiousness & $\begin{array}{l}-0.010 \\
{[0.007]}\end{array}$ & $\begin{array}{c}0.028 \\
{[0.010]^{* * *}}\end{array}$ & $\begin{array}{c}-0.016 \\
{[0.007]^{* *}}\end{array}$ \\
\hline Openness & $\begin{array}{c}0.014 \\
{[0.008]^{*}}\end{array}$ & $\begin{array}{l}0.012 \\
{[0.010]}\end{array}$ & $\begin{array}{l}0.000 \\
{[0.007]}\end{array}$ \\
\hline Constant & $\begin{array}{c}0.384 \\
{[0.114]^{* * * *}}\end{array}$ & $\begin{array}{c}-0.724 \\
{[0.155]^{* * * *}}\end{array}$ & $\begin{array}{c}0.639 \\
{[0.107]^{* * * *}}\end{array}$ \\
\hline R-squared & 0.097 & 0.149 & 0.096 \\
\hline
\end{tabular}


Table B5. OLS regressions of current and desired future job features

\begin{tabular}{|c|c|c|c|c|c|c|}
\hline & \multicolumn{2}{|c|}{ Cognitive job } & \multicolumn{2}{|c|}{ Physical job } & \multicolumn{2}{|c|}{ Social job } \\
\hline & $\begin{array}{c}\text { current } \\
{[1]} \\
\end{array}$ & $\begin{array}{c}\text { future } \\
{[2]} \\
\end{array}$ & $\begin{array}{c}\text { current } \\
{[3]} \\
\end{array}$ & $\begin{array}{c}\text { future } \\
{[4]} \\
\end{array}$ & $\begin{array}{c}\text { current } \\
{[5]} \\
\end{array}$ & $\begin{array}{c}\text { future } \\
{[5]} \\
\end{array}$ \\
\hline Female & $\begin{array}{c}-0.033 \\
{[0.012]^{* * * *}}\end{array}$ & $\begin{array}{c}-0.073 \\
{[0.012]^{* * * *}}\end{array}$ & $\begin{array}{c}-0.107 \\
{[0.019]^{* * * *}}\end{array}$ & $\begin{array}{c}-0.083 \\
{[0.014]^{* * *}}\end{array}$ & $\begin{array}{l}0.010 \\
{[0.012]}\end{array}$ & $\begin{array}{c}0.015 \\
{[0.011]} \\
\end{array}$ \\
\hline Black & $\begin{array}{c}-0.100 \\
{[0.019]^{* * *}}\end{array}$ & $\begin{array}{l}-0.035 \\
{[0.019]^{*}}\end{array}$ & $\begin{array}{l}-0.002 \\
{[0.030]}\end{array}$ & $\begin{array}{c}0.044 \\
{[0.023]^{*}}\end{array}$ & $\begin{array}{c}0.069 \\
{[0.019]^{* * *}}\end{array}$ & $\begin{array}{l}0.003 \\
{[0.018]}\end{array}$ \\
\hline Other race & $\begin{array}{l}0.012 \\
{[0.024]}\end{array}$ & $\begin{array}{c}-0.065 \\
{[0.023]^{* * *}}\end{array}$ & $\begin{array}{l}0.027 \\
{[0.037]}\end{array}$ & $\begin{array}{l}-0.016 \\
{[0.028]}\end{array}$ & $\begin{array}{l}-0.034 \\
{[0.024]}\end{array}$ & $\begin{array}{l}-0.028 \\
{[0.022]}\end{array}$ \\
\hline Hispanic & $\begin{array}{c}-0.035 \\
{[0.016]^{* *}}\end{array}$ & $\begin{array}{c}-0.054 \\
{[0.016]^{* * *}}\end{array}$ & $\begin{array}{l}0.028 \\
{[0.025]}\end{array}$ & $\begin{array}{c}-0.061 \\
{[0.019]^{* * *}}\end{array}$ & $\begin{array}{c}0.040 \\
{[0.016]^{* *}}\end{array}$ & $\begin{array}{c}-0.034 \\
{[0.015]^{* *}}\end{array}$ \\
\hline Age $50-54$ & ref. & ref. & ref. & ref. & ref. & ref. \\
\hline Age $55-59$ & $\begin{array}{l}-0.008 \\
{[0.012]}\end{array}$ & $\begin{array}{l}-0.013 \\
{[0.012]}\end{array}$ & $\begin{array}{l}-0.001 \\
{[0.019]}\end{array}$ & $\begin{array}{l}-0.005 \\
{[0.015]}\end{array}$ & $\begin{array}{c}0.022 \\
{[0.012]^{*}}\end{array}$ & $\begin{array}{c}0.024 \\
{[0.012]^{* *}}\end{array}$ \\
\hline Age $60-64$ & $\begin{array}{l}-0.023 \\
{[0.019]}\end{array}$ & $\begin{array}{l}-0.028 \\
{[0.019]}\end{array}$ & $\begin{array}{l}-0.026 \\
{[0.030]}\end{array}$ & $\begin{array}{l}-0.035 \\
{[0.022]}\end{array}$ & $\begin{array}{l}0.024 \\
{[0.019]}\end{array}$ & $\begin{array}{l}0.018 \\
{[0.018]}\end{array}$ \\
\hline Age $65-69$ & $\begin{array}{l}0.010 \\
{[0.025]}\end{array}$ & $\begin{array}{l}-0.049 \\
{[0.025]^{*}}\end{array}$ & $\begin{array}{l}-0.072 \\
{[0.040]^{*}}\end{array}$ & $\begin{array}{c}-0.094 \\
{[0.030]^{* * *}}\end{array}$ & $\begin{array}{l}0.024 \\
{[0.025]}\end{array}$ & $\begin{array}{l}-0.002 \\
{[0.024]}\end{array}$ \\
\hline Age $70-74$ & $\begin{array}{l}-0.031 \\
{[0.033]}\end{array}$ & $\begin{array}{c}-0.070 \\
{[0.033]^{* *}}\end{array}$ & $\begin{array}{c}-0.125 \\
{[0.052]^{* *}}\end{array}$ & $\begin{array}{c}-0.072 \\
{[0.040]^{*}}\end{array}$ & $\begin{array}{l}0.051 \\
{[0.033]}\end{array}$ & $\begin{array}{c}0.053 \\
{[0.032]^{*}}\end{array}$ \\
\hline Age $75-80$ & $\begin{array}{l}-0.022 \\
{[0.053]} \\
\end{array}$ & $\begin{array}{c}-0.089 \\
{[0.053]^{*}}\end{array}$ & $\begin{array}{l}-0.139 \\
{[0.084]^{*}}\end{array}$ & $\begin{array}{l}-0.095 \\
{[0.064]} \\
\end{array}$ & $\begin{array}{l}-0.088 \\
{[0.054]} \\
\end{array}$ & $\begin{array}{l}0.011 \\
{[0.051]}\end{array}$ \\
\hline High school or less & ref. & ref. & ref. & ref. & ref. & ref. \\
\hline Some college & $\begin{array}{c}0.046 \\
{[0.015]^{* * *}}\end{array}$ & $\begin{array}{c}0.067 \\
{[0.015]^{* * *}}\end{array}$ & $\begin{array}{c}-0.102 \\
{[0.023]^{* * *}}\end{array}$ & $\begin{array}{c}-0.066 \\
{[0.018]^{* * *}}\end{array}$ & $\begin{array}{l}-0.001 \\
{[0.015]}\end{array}$ & $\begin{array}{l}0.015 \\
{[0.014]}\end{array}$ \\
\hline College or more & $\begin{array}{c}0.102 \\
{[0.015]^{* * * *}}\end{array}$ & $\begin{array}{c}0.137 \\
{[0.015]^{* * *}}\end{array}$ & $\begin{array}{c}-0.214 \\
{[0.024]^{* * *}}\end{array}$ & $\begin{array}{c}-0.080 \\
{[0.018]^{* * *}}\end{array}$ & $\begin{array}{l}-0.011 \\
{[0.015]} \\
\end{array}$ & $\begin{array}{l}0.017 \\
{[0.014]}\end{array}$ \\
\hline Married & ref. & ref. & ref. & ref. & ref. & ref. \\
\hline Divorced/separated & $\begin{array}{l}0.012 \\
{[0.015]}\end{array}$ & $\begin{array}{l}0.020 \\
{[0.015]}\end{array}$ & $\begin{array}{l}0.006 \\
{[0.023]}\end{array}$ & $\begin{array}{l}0.025 \\
{[0.018]}\end{array}$ & $\begin{array}{l}-0.001 \\
{[0.015]}\end{array}$ & $\begin{array}{c}-0.026 \\
{[0.014]^{*}}\end{array}$ \\
\hline Widowed & $\begin{array}{l}-0.026 \\
{[0.033]}\end{array}$ & $\begin{array}{l}0.029 \\
{[0.033]}\end{array}$ & $\begin{array}{l}-0.016 \\
{[0.052]}\end{array}$ & $\begin{array}{c}-0.117 \\
{[0.039]^{* * *}}\end{array}$ & $\begin{array}{c}-0.067 \\
{[0.033]^{* *}}\end{array}$ & $\begin{array}{l}-0.014 \\
{[0.031]}\end{array}$ \\
\hline Never married & $\begin{array}{c}0.071 \\
{[0.020]^{* * * *}}\end{array}$ & $\begin{array}{c}0.059 \\
{[0.020]^{* * *}}\end{array}$ & $\begin{array}{l}-0.025 \\
{[0.032]} \\
\end{array}$ & $\begin{array}{c}0.045 \\
{[0.024]^{*}}\end{array}$ & $\begin{array}{l}0.010 \\
{[0.020]}\end{array}$ & $\begin{array}{l}-0.026 \\
{[0.019]} \\
\end{array}$ \\
\hline Health excellent & $\begin{array}{l}-0.027 \\
{[0.019]}\end{array}$ & $\begin{array}{l}0.008 \\
{[0.019]}\end{array}$ & $\begin{array}{l}-0.015 \\
{[0.030]}\end{array}$ & $\begin{array}{c}0.085 \\
{[0.022]^{* * * *}}\end{array}$ & $\begin{array}{l}0.001 \\
{[0.019]}\end{array}$ & $\begin{array}{l}0.000 \\
{[0.018]}\end{array}$ \\
\hline Health very good & $\begin{array}{c}-0.025 \\
{[0.012]^{* *}}\end{array}$ & $\begin{array}{l}-0.008 \\
{[0.012]}\end{array}$ & $\begin{array}{l}0.015 \\
{[0.020]}\end{array}$ & $\begin{array}{c}0.042 \\
{[0.015]^{* * *}}\end{array}$ & $\begin{array}{l}-0.003 \\
{[0.013]}\end{array}$ & $\begin{array}{l}-0.007 \\
{[0.012]}\end{array}$ \\
\hline Health good & ref. & ref. & ref. & ref. & ref. & ref. \\
\hline Health fair & $\begin{array}{c}0.037 \\
{[0.021]^{*}}\end{array}$ & $\begin{array}{l}-0.021 \\
{[0.021]}\end{array}$ & $\begin{array}{l}-0.016 \\
{[0.034]}\end{array}$ & $\begin{array}{c}-0.050 \\
{[0.025]^{* *}}\end{array}$ & $\begin{array}{l}-0.003 \\
{[0.021]}\end{array}$ & $\begin{array}{c}-0.037 \\
{[0.020]^{*}}\end{array}$ \\
\hline Health poor & $\begin{array}{c}-0.127 \\
{[0.046]^{* * *}}\end{array}$ & $\begin{array}{l}-0.062 \\
{[0.046]} \\
\end{array}$ & $\begin{array}{l}-0.008 \\
{[0.073]} \\
\end{array}$ & $\begin{array}{l}-0.075 \\
{[0.055]} \\
\end{array}$ & $\begin{array}{l}-0.085 \\
{[0.046]^{*}}\end{array}$ & $\begin{array}{l}-0.003 \\
{[0.044]}\end{array}$ \\
\hline Log family income & $\begin{array}{c}0.050 \\
{[0.009]^{* * *}}\end{array}$ & $\begin{array}{l}0.003 \\
{[0.009]}\end{array}$ & $\begin{array}{c}-0.086 \\
{[0.013]^{* * *}}\end{array}$ & $\begin{array}{c}-0.042 \\
{[0.010]^{* * *}}\end{array}$ & $\begin{array}{c}0.040 \\
{[0.009]^{* * *}}\end{array}$ & $\begin{array}{l}-0.013 \\
{[0.008]}\end{array}$ \\
\hline
\end{tabular}




\begin{tabular}{lcccccc}
\hline Full-time employee & ref. & ref. & ref. & ref. & ref. & ref. \\
Part-time employee & -0.132 & -0.034 & 0.018 & 0.004 & -0.013 & 0.011 \\
& {$[0.016]^{* * *}$} & {$[0.016]^{* *}$} & {$[0.025]$} & {$[0.019]$} & {$[0.016]$} & {$[0.015]$} \\
Full-time self-employed & -0.062 & -0.060 & 0.119 & 0.089 & 0.002 & 0.023 \\
& {$[0.020]^{* * *}$} & {$[0.020]^{* * *}$} & {$[0.032]^{* * *}$} & {$[0.024]^{* * *}$} & {$[0.020]$} & {$[0.019]$} \\
Part-time self-employed & -0.105 & -0.004 & 0.044 & 0.040 & -0.020 & -0.005 \\
& {$[0.024]^{* * *}$} & {$[0.023]$} & {$[0.037]$} & {$[0.028]$} & {$[0.024]$} & {$[0.022]$} \\
\hline Number series score & 0.002 & 0.023 & -0.003 & -0.008 & -0.017 & -0.011 \\
& {$[0.006]$} & {$[0.006]^{* * *}$} & {$[0.010]$} & {$[0.007]$} & {$[0.006]^{* * *}$} & {$[0.006]^{*}$} \\
\hline Neuroticism & 0.012 & 0.000 & -0.002 & -0.009 & -0.028 & -0.001 \\
& {$[0.006]^{* *}$} & {$[0.006]$} & {$[0.009]$} & {$[0.007]$} & {$[0.006]^{* * *}$} & {$[0.006]$} \\
Extroversion & 0.015 & -0.005 & 0.073 & 0.009 & 0.034 & 0.026 \\
& {$[0.007]^{* *}$} & {$[0.007]$} & {$[0.011]^{* * *}$} & {$[0.009]$} & {$[0.007]^{* * *}$} & {$[0.007]^{* * *}$} \\
Agreeableness & 0.006 & 0.000 & -0.020 & 0.002 & 0.021 & 0.047 \\
& {$[0.007]$} & {$[0.007]$} & {$[0.011]^{*}$} & {$[0.008]$} & {$[0.007]^{* * *}$} & {$[0.006]^{* * *}$} \\
Conscientiousness & 0.022 & 0.013 & -0.014 & 0.015 & 0.002 & -0.012 \\
& {$[0.006]^{* * *}$} & {$[0.006]^{* *}$} & {$[0.010]$} & {$[0.007]^{* *}$} & {$[0.006]$} & {$[0.006]^{* *}$} \\
Openness & 0.040 & 0.053 & -0.008 & 0.004 & 0.001 & 0.000 \\
& {$[0.006]^{* * *}$} & {$[0.006]^{* * *}$} & {$[0.010]$} & {$[0.008]$} & {$[0.006]$} & {$[0.006]$} \\
\hline Constant & 0.140 & 0.514 & 1.453 & 0.720 & 0.224 & 0.849 \\
& {$[0.096]$} & {$[0.095]^{* * *}$} & {$[0.151]^{* * *}$} & {$[0.114]^{* * *}$} & {$[0.096]^{* *}$} & {$[0.091]^{* * *}$} \\
\hline R-squared & 0.293 & 0.259 & 0.248 & 0.159 & 0.149 & 0.140 \\
\hline Notes: ALP, Age 50-80, Working for pay $, \mathrm{N}=1,288$. & Weighted. & & & &
\end{tabular}


Table B6. OLS regressions of the availability of various working conditions

\begin{tabular}{|c|c|c|c|c|}
\hline & $\begin{array}{c}\text { Part-time } \\
{[1]} \\
\end{array}$ & $\begin{array}{c}\text { Flexible } \\
\text { hours } \\
{[2]} \\
\end{array}$ & $\begin{array}{c}\text { Work from } \\
\text { home } \\
{[3]} \\
\end{array}$ & $\begin{array}{c}\text { Commute } \\
\text { time } \\
{[4]} \\
\end{array}$ \\
\hline Female & $\begin{array}{c}9.658 \\
{[3.187]^{* * *}}\end{array}$ & $\begin{array}{l}-0.337 \\
{[2.718]} \\
\end{array}$ & $\begin{array}{l}0.026 \\
{[0.029]} \\
\end{array}$ & $\begin{array}{l}-3.833 \\
{[6.111]} \\
\end{array}$ \\
\hline Black & $\begin{array}{l}-5.033 \\
{[5.139]}\end{array}$ & $\begin{array}{c}7.259 \\
{[4.360]^{*}}\end{array}$ & $\begin{array}{c}0.144 \\
{[0.046]^{* * *}}\end{array}$ & $\begin{array}{l}10.527 \\
{[9.955]}\end{array}$ \\
\hline Other race & $\begin{array}{l}-7.450 \\
{[5.710]}\end{array}$ & $\begin{array}{l}-2.502 \\
{[5.079]}\end{array}$ & $\begin{array}{l}0.079 \\
{[0.056]}\end{array}$ & $\begin{array}{c}21.275 \\
{[11.896]^{*}}\end{array}$ \\
\hline Hispanic & $\begin{array}{l}-4.598 \\
{[4.228]} \\
\end{array}$ & $\begin{array}{l}0.571 \\
{[3.709]}\end{array}$ & $\begin{array}{l}0.009 \\
{[0.039]} \\
\end{array}$ & $\begin{array}{c}24.155 \\
{[8.147]^{* * *}}\end{array}$ \\
\hline Age $50-54$ & ref. & ref. & ref. & ref. \\
\hline Age $55-59$ & $\begin{array}{c}6.699 \\
{[3.133]^{* *}}\end{array}$ & $\begin{array}{l}3.921 \\
{[2.671]}\end{array}$ & $\begin{array}{c}-0.079 \\
{[0.029]^{* * *}}\end{array}$ & $\begin{array}{l}-3.292 \\
{[6.131]}\end{array}$ \\
\hline Age 60-64 & $\begin{array}{c}12.609 \\
{[4.962]^{* *}}\end{array}$ & $\begin{array}{c}7.668 \\
{[4.136]^{*}}\end{array}$ & $\begin{array}{l}-0.070 \\
{[0.044]}\end{array}$ & $\begin{array}{l}2.084 \\
{[9.369]}\end{array}$ \\
\hline Age $65-69$ & $\begin{array}{l}11.530 \\
{[8.686]}\end{array}$ & $\begin{array}{c}6.492 \\
{[6.372]} \\
\end{array}$ & $\begin{array}{c}-0.151 \\
{[0.060]^{* *}}\end{array}$ & $\begin{array}{l}-0.391 \\
{[12.743]}\end{array}$ \\
\hline High school or less & ref. & ref. & ref. & ref. \\
\hline Some college & $\begin{array}{l}6.389 \\
{[3.919]}\end{array}$ & $\begin{array}{c}7.165 \\
{[3.387]^{* *}}\end{array}$ & $\begin{array}{l}0.011 \\
{[0.036]}\end{array}$ & $\begin{array}{l}0.168 \\
{[7.576]}\end{array}$ \\
\hline College or more & $\begin{array}{l}3.959 \\
{[4.168]}\end{array}$ & $\begin{array}{c}13.253 \\
{[3.613]^{* * * *}}\end{array}$ & $\begin{array}{l}0.042 \\
{[0.038]}\end{array}$ & $\begin{array}{r}-11.638 \\
{[18.501]} \\
\end{array}$ \\
\hline Married & ref. & ref. & ref. & ref. \\
\hline Divorced/separated & $\begin{array}{l}-0.049 \\
{[3.935]}\end{array}$ & $\begin{array}{l}4.002 \\
{[3.459]}\end{array}$ & $\begin{array}{c}0.062 \\
{[0.036]^{*}}\end{array}$ & $\begin{array}{c}29.752 \\
{[10.326]^{* * *}}\end{array}$ \\
\hline Widowed & $\begin{array}{l}18.671 \\
{[9.585]^{*}}\end{array}$ & $\begin{array}{c}25.363 \\
{[7.717]^{* * *}}\end{array}$ & $\begin{array}{l}0.067 \\
{[0.087]}\end{array}$ & $\begin{array}{l}-6.811 \\
{[9.607]}\end{array}$ \\
\hline Never married & $\begin{array}{l}-6.210 \\
{[5.629]} \\
\end{array}$ & $\begin{array}{l}-0.041 \\
{[4.700]} \\
\end{array}$ & $\begin{array}{l}0.072 \\
{[0.049]} \\
\end{array}$ & $\begin{array}{r}-7.557 \\
{[6.387]} \\
\end{array}$ \\
\hline Health excellent & $\begin{array}{l}6.777 \\
{[5.064]}\end{array}$ & $\begin{array}{l}-0.594 \\
{[4.352]}\end{array}$ & $\begin{array}{c}0.094 \\
{[0.045]^{* *}}\end{array}$ & $\begin{array}{l}-20.380 \\
{[10.786]^{*}}\end{array}$ \\
\hline Health very good & $\begin{array}{l}-2.240 \\
{[3.260]}\end{array}$ & $\begin{array}{l}-4.945 \\
{[2.831]^{*}}\end{array}$ & $\begin{array}{c}0.094 \\
{[0.030]^{* * *}}\end{array}$ & $\begin{array}{c}-23.338 \\
{[23.238]}\end{array}$ \\
\hline Health good & ref. & ref. & ref. & ref. \\
\hline Health fair & $\begin{array}{l}-15.106 \\
{[5.886]^{* * *}}\end{array}$ & $\begin{array}{l}-11.693 \\
{[4.860]^{* *}}\end{array}$ & $\begin{array}{c}0.144 \\
{[0.051]^{* * *}}\end{array}$ & $\begin{array}{c}-18.195 \\
{[4.529]^{* * *}}\end{array}$ \\
\hline Health poor & $\begin{array}{c}5.767 \\
{[18.262]}\end{array}$ & $\begin{array}{c}6.956 \\
{[11.069]}\end{array}$ & $\begin{array}{l}0.104 \\
{[0.110]}\end{array}$ & $\begin{array}{c}0.000 \\
{[.]}\end{array}$ \\
\hline Log family income & $\begin{array}{l}-1.731 \\
{[2.984]} \\
\end{array}$ & $\begin{array}{c}6.751 \\
{[2.248]^{* * *}}\end{array}$ & $\begin{array}{c}0.082 \\
{[0.021]^{* * *}}\end{array}$ & $\begin{array}{l}-1.628 \\
{[8.312]}\end{array}$ \\
\hline Full-time employee & - & ref. & ref. & ref. \\
\hline Part-time employee & $\begin{array}{l}- \\
-\end{array}$ & $\begin{array}{c}20.177 \\
{[3.572]^{* * *}}\end{array}$ & $\begin{array}{l}0.050 \\
{[0.039]}\end{array}$ & $\begin{array}{l}-1.628 \\
{[8.312]}\end{array}$ \\
\hline Full-time self-employed & - & - & 0.453 & -1.961 \\
\hline
\end{tabular}




\begin{tabular}{lcccc} 
& - & - & {$[0.049]^{* * *}$} & {$[10.419]$} \\
Part-time self-employed & - & - & 0.555 & -19.460 \\
\hline Current job cognitive score & -14.229 & -16.330 & 0.254 & 0.368 \\
& {$[7.844]^{*}$} & {$[6.542]^{* *}$} & {$[0.069]^{* * *}$} & {$[14.596]$} \\
Current job physical score & 15.108 & -4.646 & -0.284 & 25.789 \\
& {$[5.074]^{* * *}$} & {$[4.229]$} & {$[0.043]^{* * *}$} & {$[9.135]^{* * *}$} \\
Current job social score & 20.036 & 15.392 & -0.022 & -9.465 \\
& {$[7.342]^{* * *}$} & {$[6.303]^{* *}$} & {$[0.069]$} & {$[14.504]$} \\
\hline Number series score & 2.399 & -2.614 & 0.001 & -3.674 \\
& {$[1.695]$} & {$[1.408]^{*}$} & {$[0.015]$} & {$[3.092]$} \\
\hline Neuroticism & -3.696 & -2.741 & -0.014 & -3.735 \\
Extroversion & {$[1.536]^{* *}$} & {$[1.311]^{* *}$} & {$[0.014]$} & {$[3.026]$} \\
Agreeableness & 3.994 & 3.540 & -0.011 & 14.905 \\
& {$[1.912]^{* *}$} & {$[1.654]^{* *}$} & {$[0.018]$} & {$[3.777]^{* * *}$} \\
Conscientiousness & 1.388 & 0.767 & -0.016 & -4.294 \\
Openness & {$[1.688]$} & {$[1.527]$} & {$[0.016]$} & {$[3.422]$} \\
& 1.798 & -0.429 & -0.023 & 4.030 \\
\hline Constant & {$[1.706]$} & {$[1.487]$} & {$[0.015]$} & {$[3.189]$} \\
& 0.434 & 1.483 & 0.062 & -10.649 \\
\hline R-squared & {$[1.676]$} & {$[1.434]$} & {$[0.016]^{* * *}$} & {$[3.301]^{* * *}$} \\
$\mathrm{~N}$ & 43.361 & -45.875 & -0.697 & 247.072 \\
\hline
\end{tabular}


Table B7. The distribution of the subjective conditional probabilities of working past age 70

\begin{tabular}{|c|c|c|c|c|c|c|c|}
\hline \multirow[b]{3}{*}{ Panel A: Job characteristics } & \multirow[b]{2}{*}{$\mathrm{N}$} & \multicolumn{3}{|c|}{ Without condition } & \multicolumn{3}{|c|}{ With condition } \\
\hline & & $\mathrm{P}=0$ & $0<\mathrm{P}<100$ & $\mathrm{P}=100$ & $\mathrm{P}=0$ & $0<\mathrm{P}<100$ & $\mathrm{P}=100$ \\
\hline & [1] & [2] & {$[3]$} & [4] & {$[5]$} & [6] & [7] \\
\hline A.1. Employer offers flexible schedule & 656 & 0.602 & 0.351 & 0.047 & 0.299 & 0.660 & 0.073 \\
\hline A.2. Job not stressful & 990 & 0.198 & 0.731 & 0.071 & 0.145 & 0.788 & 0.127 \\
\hline A.3. Job requires no physical effort & 975 & 0.203 & 0.726 & 0.071 & 0.162 & 0.771 & 0.122 \\
\hline A.4. Become self-employed & 712 & 0.329 & 0.611 & 0.060 & 0.239 & 0.708 & 0.135 \\
\hline A.5. Short commute & 243 & 0.251 & 0.712 & 0.037 & 0.235 & 0.733 & 0.082 \\
\hline A.6. Work from home & 989 & 0.218 & 0.713 & 0.069 & 0.180 & 0.753 & 0.108 \\
\hline A.7. Job requires no concentration & 972 & 0.201 & 0.729 & 0.070 & 0.166 & 0.771 & 0.096 \\
\hline A.8. Switch to part-time at current emp. & 543 & 0.278 & 0.643 & 0.079 & 0.247 & 0.680 & 0.101 \\
\hline \multicolumn{8}{|l|}{ Panel B: Other factors } \\
\hline B.1. Health: good or better & 1018 & 0.380 & 0.595 & 0.025 & 0.164 & 0.811 & 0.102 \\
\hline B.2. Wealth: $\$ 500 \mathrm{k}$ more & 1007 & 0.204 & 0.725 & 0.071 & 0.465 & 0.482 & 0.031 \\
\hline B.3. Wage: $20 \%$ more & 338 & 0.172 & 0.793 & 0.036 & 0.180 & 0.784 & 0.092 \\
\hline B.4. Longevity: 10 more years & 662 & 0.204 & 0.736 & 0.060 & 0.233 & 0.710 & 0.089 \\
\hline
\end{tabular}

Notes: ALP, age 50-69, Working for pay, Unweighted. The table shows the fraction of the sample that gave different types of probability answers. The probabilities are the subjective probabilities of working past age 70 conditional on having or not having certain job characteristics.

Table B8. The distribution of the sign of the subjective causal effects of work characteristics on probabilities of working past age 70

\begin{tabular}{|c|c|c|c|c|}
\hline & $\mathrm{N}$ & $\mathrm{P}_{0}<\mathrm{P}_{1}$ & $\mathrm{P}_{0}=\mathrm{P}_{1}$ & $\mathrm{P}_{0}>\mathrm{P}_{1}$ \\
\hline Panel A: Job characteristics & {$[1]$} & {$[2]$} & [3] & [4] \\
\hline A.1. Employer offers flexible schedule & 656 & 0.465 & 0.424 & 0.111 \\
\hline A.2. Job not stressful & 990 & 0.487 & 0.320 & 0.193 \\
\hline A.3. Job requires no physical effort & 975 & 0.470 & 0.343 & 0.188 \\
\hline A.4. Become self-employed & 712 & 0.448 & 0.298 & 0.254 \\
\hline A.5. Short commute & 243 & 0.461 & 0.346 & 0.193 \\
\hline A.6. Work from home & 989 & 0.450 & 0.344 & 0.206 \\
\hline A.7. Job requires no concentration & 972 & 0.425 & 0.333 & 0.242 \\
\hline A.8. Switch to part-time at current emp. & 543 & 0.341 & 0.396 & 0.263 \\
\hline \multicolumn{5}{|l|}{ Panel B: Other factors } \\
\hline B.1. Health: good or better & 1018 & 0.729 & 0.256 & 0.015 \\
\hline B.2. Wealth: $\$ 500 \mathrm{k}$ more & 1007 & 0.111 & 0.280 & 0.609 \\
\hline B.3. Wage: $20 \%$ more & 338 & 0.642 & 0.325 & 0.033 \\
\hline B.4. Longevity: 10 more years & 662 & 0.364 & 0.329 & 0.307 \\
\hline
\end{tabular}

Notes: ALP, age 50-69, Working for pay, Unweighted. $\mathrm{P}_{0}$ and $\mathrm{P}_{1}$ refer to the conditional probabilities without and with the condition respectively. 


\section{References}

Baird, M. D., \& Pollard, M. (2017). The RAND American Life Panel: Technical Description. RR-1651, 2017, https://www.rand.org/pubs/research_reports/RR1651.html.

Barnes-Farrell, J. L. (2003). Beyond Health and Wealth: Attitudinal and Other Influences on Retirement Decision-making. In G.A. Adams \& T.A. Beehr (eds.), Retirement: Reasons, processes, and results. New York, NY: Springer, 159-187.

Beehr, T. A., \& Bennett, M. M. (2015). Working After Retirement: Features of Bridge Employment and Research Directions. Work, Aging and Retirement, 1(1), 112-128.

Belbase, A., Sanzenbacher, G. T., \& Gillis, C. M. (2016). How Do Job Skills that Decline with Age Affect White-collar Workers? Issue brief, 16-6.

Blundell, R., French, E., \& Tetlow, G. (2016). Retirement Incentives and Labor Supply. Handbook of the Economics of Population Aging, Elsevier.

Borghans, L., Duckworth, A. L., Heckman, J. J., \& Ter Weel, B. (2008). The Economics and Psychology of Personality Traits. Journal of Human Resources, 43(4), 972-1059.

Börsch-Supan, A., \& Winter, J. (2004). How to Make Internet Surveys Representative: A Case Study of a Two-step Weighting Procedure. MEA Discussion Paper, No. 04067. Munich Center for the Economics of Aging (MEA) at the Max Planck Institute for Social Law and Social Policy.

Bound, J., Cullen, J., Nichols, A., \& Schmidt, L. (2004). The Welfare Implications of Changing Disability Insurance Benefit Generosity. Journal of Public Economics. 88(12), 24872514. 
Bound, J., Stinebrickner, T., \& Waidmann, T. (2010). Health, Economic Resources and the Work Decisions of Older Men. Journal of Econometrics, 156(1), 106-129.

Feldman, D. C., \& Beehr, T. A. (2011). A Three-phase Model of Retirement Decision-making. American Psychologist, 66(3), 193-203.

Fisher, G. G., Chaffee, D. S., \& Sonnega, A. (2016). Retirement Timing: A Review and Recommendations for Future Research. Work, Aging and Retirement, 2(2), 230-261.

Fisher, G. G., McArdle, J. J., McCammon, R. J., Sonnega, A., \& Weir, D. (2013). New Measures of Fluid Intelligence in the HRS. Ann Arbor, Michigan: Institute for Social Research, University of Michigan.

French, E., \& Jones, J. B. (2011). The Effects of Health Insurance and Self-Insurance on Retirement Behavior. Econometrica, 79(3), 693-732.

Gruber J., \& Wise D.A. (eds.) (2004). Social Security Programs and Retirement Around the World: Micro-estimation. Chicago, IL: University of Chicago Press.

Gustman, A. L., \& Steinmeier, T. L. (2005). The Social Security Early Entitlement Age in a Structural Model of Retirement and Wealth. Journal of Public Economics, 89(2-3), 441463.

Hudomiet, P., Hurd, M., Rohwedder, S., \& Willis, R. J. (2018a). The Effect of Physical and Cognitive Decline at Older Ages on Work and Retirement: Evidence from Occupational Job Demands and Job Mismatch. Michigan Retirement Research Center Research Paper, No. 2017-372.

Hudomiet, P., Hurd, M., \& Rohwedder, S. (2018b). The Causal Effects of Economic Incentives, Health and Job Characteristics on Retirement: Estimates Based on Subjective Conditional 
Probabilities. Working Paper, presented at the 2018 Working Longer and Retirement Conference at SIEPR.

Hudomiet, P., Parker, A. M., \& Rohwedder, S. (2018c). Cognitive Ability, Personality, and Pathways to Retirement: An Exploratory Study. Work, Aging and Retirement, 4(1), 5266.

John, O. P., \& Srivastava, S. (1999). The Big Five Trait Taxonomy: History, Measurement and Theoretical Perspectives. In L. A. Pervin and O. P. John (eds.), Handbook of Personality: Theory and Research, New York, NY: The Guilford Press, 102-38.

Kantarci, T. \& van Soest, A. (2008). Gradual Retirement: Preferences and Limitations. De Economist, Springer, 156, 113-144.

Karoly, L. A. \& Zissimopoulos, J. M. (2004). Self-Employment Among Older U.S. Workers. Monthly Labor Review. 127(7), 24-47.

Katz, L.F. \& Krueger, A.B. (2016). The Rise and Nature of Alternative Work Arrangements in the United States, 1995-2015. NBER Working Papers 22667. Boston, MA: National Bureau of Economic Research.

Maestas, N. (2010). Back to Work: Expectations and Realizations of Work After Retirement. Journal of Human Resources, 45, 718-748.

Maestas, N., Mullen, K., Powell, D., von Wachter, T., \& Wenger, J. (2018). The Value of Working Conditions in the United States and Implications for the Structure of Wages. NBER Working Paper, No. 25204.

Maestas, N., Mullen, K., \& Strand, A. (2013). Does Disability Insurance Receipt Discourage Work? Using Examiner Assignment to Estimate Causal Effects of SSDI Receipt. American Economic Review, 103(5), 1797-1829. 
Mather, M., Jacobsen, L. A., \& Pollard, K. M. (2015). Aging in the United States. Population Reference Bureau.

McArdle, J., Smith J. P., \& Willis R. J. (2009). Cognition and Economic Outcomes in the Health and Retirement Survey, NBER Working Paper, No. 15266.

Morgeson, F. P. \& Humphrey, S. E. (2006). The Work Design Questionnaire (WDQ):

Developing and Validating a Comprehensive Measure for Assessing Job Design and the Nature of Work. Journal of Applied Psychology, 91(6):1321-1339.

Quinn, J. F. (1996). The Role of Bridge Job in the Retirement Patterns of Older Americans in the 1990s. MA: Boston College Economics Working Paper, No. 324.

Salthouse, T. (2012). Consequences of Age-Related Cognitive Declines. Annual Review of Psychology, 63, 201-226.

Smith, J., Fisher, G., Ryan, L., Clarke, P., House, J., \& Weir, D. (2013). Psychosocial and Lifestyle Questionnaire, 2006-2010 (Documentation Report, Core Section LB). Retrieved from the University of Michigan. Institute for Social Research website: Accessed September 20, 2015: http://hrsonline.isr.umich.edu/sitedocs/userg/HRS20062010SAQdoc.pdf.

Spirduso, W. W., Francis, K. L., \& MacRae, P. G. (2005). Physical Dimensions of Aging. Champaign, IL: Human Kinetics, 275-287.

Van Soest, A., Kapteyn, A., \& Zissimopoulos, J. (2007). Using Stated Preferences Data to Analyze Preferences for Full and Partial Retirement, IZA Discussion Paper, No. 2785. 